Russian Academy of Sciences, Far Eastern Branch

Botanical Garden-Institute

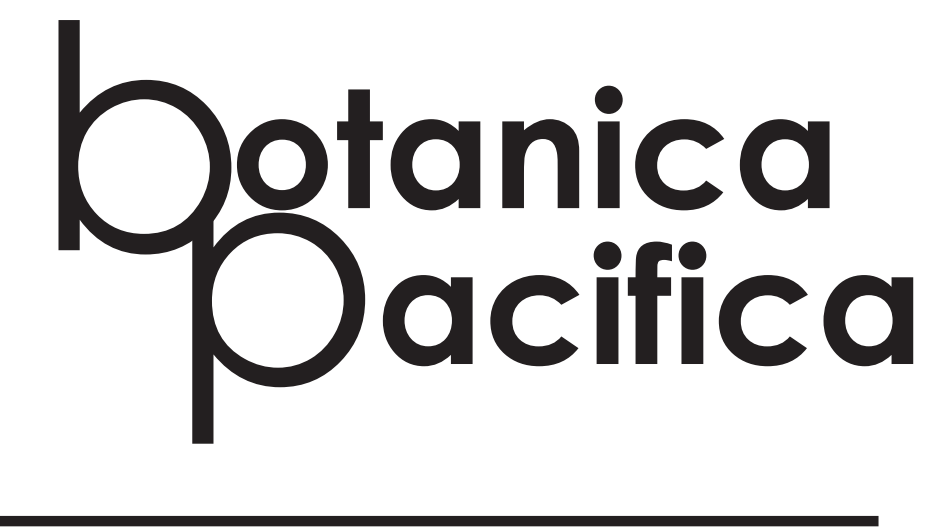

A JOURNAL OF PLANT SCIENCE
AND CONSERVATION

VOLUME 9, NO. 12020 


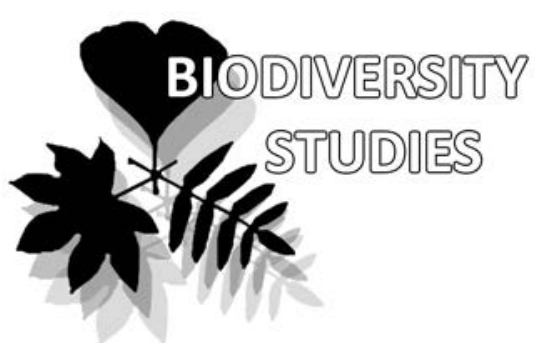

\section{Invasive plants in flora of the Russian Far East: the checklist and comments}

Yulia K. Vinogradova ${ }^{1}$, Elena V. Aistova ${ }^{2}$, Lyubov A. Antonova ${ }^{3}$, Olga A. Chernyagina, ${ }^{4,5}$ Elena A. Chubar ${ }^{6}$, Galina F. Darman ${ }^{2}$, Elizaveta A. Devyatova ${ }^{4}$, Maria G. Khoreva ${ }^{7}$, Olga V. Kotenko ${ }^{2}$, Elena A. Marchuk ${ }^{8}$, Evgenii G. Nikolin ${ }^{9}$, Sergey V. Prokopenko ${ }^{10}$, Tamara A. Rubtsova ${ }^{11}$, Victor V. Sheiko ${ }^{12}$,

Ekaterina P. Kudryavtseva ${ }^{13}$ \& Pavel. V. Krestov ${ }^{8}$

Yulia K. Vinogradova ${ }^{1 *}$

e-mail: gbsad@mail.ru

Elena V. Aistova ${ }^{2}$

Lyubov A. Antonova ${ }^{3}$

Olga A. Chernyagina $a^{4,5}$

Elena A. Chubar ${ }^{6}$

Galina F. Darman ${ }^{2}$

Elizaveta A. Devyatova ${ }^{4}$

Maria G. Khoreva ${ }^{7}$

Olga V. Kotenko ${ }^{2}$

Elena A. Marchuk ${ }^{8}$

Evgenii G. Nikolin?

Sergey V. Prokopenko ${ }^{10}$

Tamara A. Rubtsova ${ }^{11}$

Victor V. Sheiko ${ }^{12}$

Ekaterina P. Kudryavtseva ${ }^{13}$

Pavel V. Krestov ${ }^{8}$

${ }^{1}$ Tsitsin Main Botanical Garden RAS, Moscow, Russia

2 Amur branch of the Botanical GardenInstitute FEB RAS, Blagoveshchensk, Russia

${ }^{3}$ Institute of Water and Ecology Problems FEB RAS, Khabarovsk, Russia

${ }^{4}$ Vitus Bering Kamchatka State University, Petropavlovsk-Kamchatsky, Russia

${ }^{5}$ Kamchatka Branch of Pacific Institute of Geography FEB RAS, PetropavlovskKamchatsky, Russia

${ }^{6}$ Far Eastern Marine Nature Reserve Branch of the National Scientific Center for Marine Biology FEB RAS, Vladivostok, Russia

${ }^{7}$ Institute of the Biological Problems of the North, Magadan, Russia

${ }^{8}$ Botanical Garden-Institute FEB RAS,

Vladivostok, Russia

${ }^{9}$ Institute for Biological Problems of Cryolithozone SB RAS, Yakutsk, Russia

${ }^{10}$ Federal Scientific Center of the East Asia Terrestrial Biodiversity FEB RAS,

Vladivostok, Russia

${ }^{11}$ Institute for Complex Analvsis of Regional Problems FEB RAS, Birobidjan, Russia

${ }^{12}$ Sakhalin Branch of Botanical GardenInstitute FEB RAS, Yuzhno-Sakhalinsk, Russiaa

${ }^{13}$ Pacific Institute of Geography FEB

RAS, Vladivostok, Russia

* corresponding author

Manuscript received: 02.08.2019

Review completed: 06.10.2019

Accepted for publication: 03.04.2020

Published online: 06.04.2019

\begin{abstract}
A B S T R A C T
The paper presents a checklist of the species invading the natural phytocenoses of the Far Eastern Federal District of Russia (FEFD) that includes $40.6 \%$ of the state territory. It summarizes original data on distribution, habitats and invasiveness status (IS) of 116 alien species belonging to 99 genera of 32 families. Eighteen species are only beginning to invade natural cenoses and have IS 3; 76 species intensively invade natural cenoses and are listed in the group with IS 2. Transformer are represented by 22 species with IS 1, of which Ambrosia artemisiifolia, Bidens frondosa, Solidago canadensis, Impatiens glandulifera and Hordeum jubatum are most widely distributed. A very strong heterogeneity of the soil and climate conditions accounts for a considerable disparity in the list of alien species between various territorial districts of the FEFD. Many species that actively colonize southern districts do not occur in the north, or only individual plants of them are reported. The article is a step towards the preparation of the Black Book of the Russian Far East flora and the basis for making decision on prevention the economic and environmental damage of the natural biodiversity of the region.
\end{abstract}

K e y w o r d s : alien species, invasion, Far Eastern Federal District, transformers

\section{P E 3 Ю M E}

Виноградова Ю.К., Аистова Е.В., Антонова М.А., Чернягина О.А., Чубарь Е.А., Аарман Г.Ф., Аевятова Е.А., Хорева М.Г., Котенко О.В., Марчук Е.А., Николин Е.Г., Прокопенко С.В., Рубцова Т.А., Шейко В.В., Ккарявцева Е.П., Крестов П.В. Инвазивные растения во фморе российского Аальнего Востока: аннотированный чеклист. Состав ен чек- ист инвазионных видов, вторгающихся в естественные фитоценозы Аальневосточного федерального округа ( $\triangle \mathrm{BO})$, охватывающего 40,6 \% площади России. Обобщены оригинацьные сведения о распространении, местообитаниях и инвазионном статусе 116 чужеродных видов из 99 родов и 32 семейств. 18 вилов только начинают внеАряться в естественные ценозы и имеют инвазионный статус 3; 76 вилов активно внедряются в естественные ценозы и отнесены в группу со статусом 2. К видам-трансформерам с инвазионным статусом 1 относятся 22 вила, наиболее широко из них расселились Ambrosia artemisiifolia, Bidens frondosa, Solidago canadensis, Impatiens glandulifera и Hordeum jubatum. Симьнейшая неоднородность почвенно-климатических условий обусловливает значительное различие перечней чужеродных видов между разными субъектами $А В О$. Многие виды, активно захватывающие южные районы, на севере не встречаются, Аибо отмечены единично. Статья явАяется необходимым этапом создания "Черной Книги" флоры АаАьнего Востока и основой Аля принятия конкретных Аействий по преАОтвращению и минимизации экономического и экологического ущерба от инвазии чужеродных видов.

КАючевые слова: чужеродные виды, инвазия, Аальневосточный Федеральный округ, виды-трансформеры

Invasive alien plants can be a serious threat for the native species, communities and ecosystems in many regions of the world (McGeoch et al. 2010, Lemke et al. 2013, TeBeest et al. 2014). Invasive alien species alter ecosystems' functions and cycles (Raizada et al. 2008), reduce natural species diversity through competition, hybridization and side effects (Ellstrand \& Schierenbeck 2000, Gaertner et al. 2009), alter the structure of communities and genetic diversity (Plant Invasions 2013). Invasive species rarely cause direct economic damage but they all negatively affect the region's ecology by altering the diversity and structure of communities (Vilá et al. 2009). The number and abundance of alien species seems to be closely linked to the considerable increase in the scope and volume of trade and transport communication, especially during the past 25 years (Levine \& D'Antonio 2003, 
Ruiz \& Carlton 2003, Hulme et al. 2009). That is why early identification, inventory and intensive elimination of invasive species are essential, especially in the context of the fast growth of tourism and trade (Monaco \& Genovesi 2014).

The growing recognition of the negative impact of biological invasions on natural biodiversity led to the development of the Convention on Biological Diversity and the establishment of the Scientific Committee on Problems of the Environment (SCOPE) on biological invasions. The legislation of the European Community lists the prevention, minimization and mitigation of the negative impact on biodiversity of both intentionally and unintentionally introduced invasive alien species as high-priority tasks (Regulation EU № 1143/2014). Taking inventory of alien species (Hejda et al. 2009, Plant Invasions 2013, Nagendra et al. 2013, Monaco \& Genovesi 2014), which will make it possible to assess the nature of the spread of alien species and predict the rate of their spread (Hulme 2003) is recognized as a priority. The inventory of alien plant species is a basis for the development of a strategic long-term plan for the conservation of the region's biodiversity and prevention of the invasion of other non-native plant pests and diseases.

In Russia, the lists of the most aggressive alien plant species apart from individual articles (Panasenko 2014, Starodubtseva et al. 2014, Abramova 2013, Vinogradova et al. 2018) are published as Black Books. This work has been completed for Central Russia, Tver Region, Nizhny Novgorod Region, Siberia and Udmurtia (Vinogradova et al. 2010, Vinogradova et al. 2011, Mininzon \& Trostina 2014, Ebel et al. 2016, Baranova 2016). For the Russian Far East, the spread of invasive alien species has not been summarized yet, so the purpose of this study is to make the list of invasive species invading the natural plant communities of the region.

\section{MATERIAL AND METHODS}

The territory the Far Eastern Federal District (FEFD) covers an area of $6952555 \mathrm{~km}^{2}$, which is $40.6 \%$ of the total area of the country.

The work is based on the original data on the distribution and the invasiveness status of alien species provided by the researchers working in each district (authors of the article) for 9 territorial subjects of the FEFD:

Amur Region [Amur] - E.V. Aistova \& G.F. Darman; Chukotka Autonomous Area [Chuk] - M.G. Khoreva; Jewish Autonomous Region [Jew] - L.A. Antonova \& T.A. Rubtsova;

Kamchatka Territory [Kam] - E.A. Devyatova \& O.A. Chernyagina;

Khabarovsk Territory [Khab] - L.A. Antonova;

Magadan Region [Mag] - D.S. Lysenko \& M.G. Khoreva;

Primorye Territory [Prim] - E.A. Marchuk, S.V. Prokopenko, E.P. Kudryavtseva \& E.A. Chubar;

Republic of Sakha (Yakutia) [Yak] - E.G. Nikolin;

Sakhalin Region [Sakh] - V.V. Sheiko, E.A. Marchuk \& M.G. Khoreva.

The original data were added with numerous published materials and herbaria specimens (MHA, MW, LE, VBGI,
VLA, MAG, SASY). The data for the Republic of Buryatia [Bur] and Zabaykalsky Territory [Zab] were previously published by Ebel et al. (2016).

General species distribution in Asian Russia was shown according the scheme of floristic districts used by Kharkevich (1985) and Malyshev (1988) in the regional floras (Fig. 1).

The species invasiveness status was evaluated based on the level of ability of invasive species to affect natural ecosystems and on the peculiarities of their dissemination (Notov et al. 2011):

Status 1 (IS 1) - transformers (Richardson et al. 2000), which actively invade into the natural and seminatural communities; change the ecosystems; disrupt succession processes; are dominants, forming single-species dense plant communities; and force out and (or) obstruct the reproduction of native species;

Status 2 (IS 2) - alien species actively spreading and becoming naturalized within disturbed, seminatural and natural habitats;

Status 3 (IS 3) - alien species currently spreading and naturalizing in disturbed habitats; in the course of further naturalization, some of them will apparently be able to establish themselves in seminatural and natural communities;

Status 4 (IS 4) - potentially invasive species, which are able to propagate within places of introduction or behave as invasive species in adjacent regions.

Uncertain status (IS ?) - alien species that have the potential to invade natural plant communities, but are poorly studied at the present time in a particular region.

The species with an East Asian distribution, which were listed as invasive ones in any of the administrative territories of the FEFD, were not included in the list, as this process may be also viewed as the expansion of the natural habitat due to climate change. For example, Euphrasia maximowiczii Wettst. is one of such "controversial" species. Besides, species with a broad natural habitat, which in some of the regions are considered native, and in others as invasive taxa. For example, Acetosella vulgaris (Koch) Fourr., Aconogonon weyrichii (F. Schmidt) H. Hara, Agrostis stolonifera L., Alisma plantago-aquatica L., Alopecurus arundinaceus Poir., Bromopsis inermis (Leyss.) Holub, Calamagrostis epigeios (L.) Roth, Echinochloa crusgalli (L.) Beauv. Gnaphalium uliginosum L., Polygonum aviculare L., Reynoutria sachalinensis (Fr. Schmidt) Nakai, Sonchus arvensis L., Vicia cracca L. were not included in the list either. Listing the invasive plant species we assumed that the simultaneous inclusion of both native and invasive species in the list will block the elaboration of the legal documents for the control of the most aggressive taxa across the FEFD. These species may be later included in the regional lists of invasive species, and their distribution must be controlled within specific areas. We were guided by the same argument when we did not include in the list alien species that are classified as invasive in only one of the regions considered, but have not yet been registered in others. This primarily refers to the Primorsky Territory, where the largest number of species has been found that intrude into natural coenoses, for example, Turgenia latifolia (L.) Hoffm., Hemerocallis fulva (L.) L., Epilobium hirsutum L., Centaurea scabiosa L., Heliopsis helianthoides (L.) Sweet., Leucanthemum vulgare Lam., Xanthoxalis stricta (L.) Small., Securigera varia (L.) Lassen., Verbena bracteosa Michx., Plantago salsa Pall. 


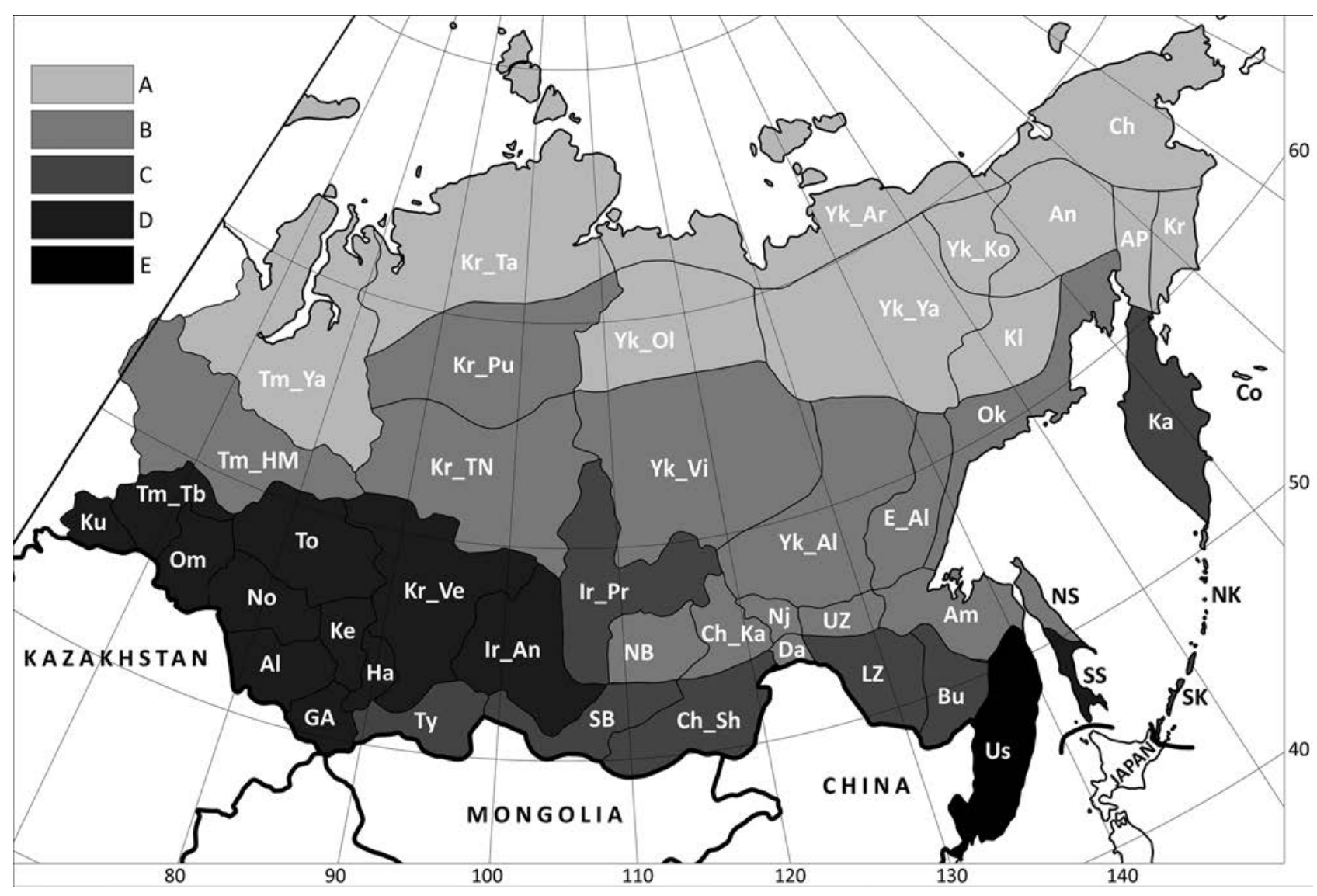

Figure 1 Floristic districts of Asian Russia used in the "Flora of the Soviet Far East" (Kharkevich 1985) and "Flora of Siberia" (Krasnoborov 1988). Floristic districts: $\mathrm{Ch}$ - Chukotskii, $\mathrm{Kr}$ - Koriakskii, AP - Anadyrsko-Penzhinskii, Co - Komandorskii, Ka - Kamchatskii; NK - Severo-Kurilskii; SK - Yuzhno-Kurilskii; An - Aniuiskii; Ok - Okhotskii; Kl - Kolymskii, NS - Severo-Sakhalinskii; SS - Yuzhno-Sakhalinskii; Am - Amginskii; Us - Ussuriiskii; Bu - Bureinskii; UZ - Verkhne-Zeiskii; LZ - Nizhne-Zeiskii; Nj - Niukzhinskii; Da - Daurskii; Yk_Ar - Yakutskii Arcticheskii; Yk_Ko - Yakutskii Kolymskii; Yk_Al - Yakutskii Aldanskii; Yk_Ya - Yakutskii Yano-Indigirskii; Yk_Ol - Yakutskii Oleneksko-Nizhnelenskii; Yk_Vi -Yakutskii Viliuisko-Verkhnelenskii; Kr_Pu - Krasnoyarskii Putoranskii; Kr_Ta - Krasnoyarskii Taimyrskii;Tm_Ya - Tiumenskii Yamalo-Nenetskii; Tm_HM - Tiumenskii Hanty-Mansiiskii; Tm_Tb - Tiumenskii Tobolskii; $\mathrm{Ku}$ - Kurganskii; Om - Omskii; To - Tomskii; No - Novosibirskii; Al - Altaiskii Barnaulskii; Ke - Kemerovskii; GA - Altaiskii Gornoaltaiskii; Ha - Krasnoyarskii Hakasskii; Ty - Tuvinskii; Kr_TN - Krasnoyarskii Tungusskii; Kr_Ve - Krasnoyarskii Verkhneyenisseiskii; Ir_An - Irkutskii Angaro-Sayanskii; Ir_Pr - Irkutskii Prilensko-Katangskii; NB - Buriatskii Severobaikalskii; Ch_Ka - Chitinskii Kalarskii; SB - Buriatskii Yuzhnobaikalskii; Ch_Sh - Chitinskii Shilko-Argunskii. Legend: A - number of invasive species from 0 to $19 ; \mathrm{B}$ - from 20 to $39 ; \mathrm{C}$ - from 40 to $59 ; \mathrm{D}$ - from 60 to $79 ; \mathrm{E}-\geq 80$.

We follow the broad species concept in this study. For example, Rudbeckia bicolor Nutt. includes R. birta var. pulcherrima Farw. Phalacroloma annum (L.) Dumort and Ph. strigosum (Muehl. ex Willd.) Tzvelev are combined together. This approach is based on the assumption that closely related invasive species must be controlled in full in broad scale and not only by botanists but also by conservation managers and volunteers. The nomenclature follows The Plant List database.

\section{LIST OF INVASIVE PLANT SPECIES OF THE FAR EASTERN FEDERAL DISTRICT}

\section{ACERACEAE}

Acer negundo L.

Distribution in Asian Russia: Bu, Us, SS.

Prim: IS 1; reproduces very well by seed, often occurs in natural communities, mostly floodplain communities, especially within the city boundaries or in the proximity of populated areas; in the vicinity of the town of Spassk forms forests in the floodplain of the Spasovka River replacing the native Fraxinus mandshurica and Ulmus japonica forests; Sakh:
IS 2; reported from the southwestern, southeastern and Susunai mountain geobotanical districts (Barkalov \& Taran 2004); Khab: IS 1; widely used in landscaping; since the end of the 20th century, the abundant seed reproduction in parks, yards, sometimes lawns has been observed in the southern and central districts; escapes from culture forming thickets along rills, shallow rivers within the boundaries of populated areas (Antonova 2012, Vinogradova et al. 2018); Jew: IS 2; actively invades seminatural communities (Rubtsova 2000, 2002); Amur: IS 2; Bur: IS 4; colonizes and naturalizes only disturbed habitats (Ebel et al. 2016); Mag: IS ?; individual plants occur in plantations in the city of Magadan, does not reproduce; Kam: IS 2; occurs in Petropavlovsk-Kamchatsky in the Nikolskaya Sopka area, the natural and historical site in forest margins and under the canopy of Betula ermanii forests (Devyatova et al. 2016).

\section{AMARANTHACEAE \\ Amaranthus retroflexus $\mathrm{L}$.}

Distribution in Asian Russia: Bu, Us, Da, LZ, Am, Tm Tb, Ku, Om, To, No, Ke, Al, GA, Kr_Pu, Ha, Kr_Ve, Ty, Ir_An, Ch_Sh.

Prim: IS 3; a common weed species growing in populated areas, on waste grounds, in kitchen gardens, fields; Sakh: 
IS 3; reported from the Western Sakhalin montane area and Southern Sakhalin Plain (Barkalov \& Taran 2004); Khab: IS 4; persistent segetal weed, less ruderal, sometimes grows in roadside areas, on river pebbles (Antonova 2012, Vinogradova et al. 2018); Jew: IS 3; reported mostly from kitchen gardens (Rubtsova 2017); Amur: IS 3; a prevalent species in ruderal habitats, often occurs in soybean and grain crops (Aistova 2009); Yak: IS 3; included in the list of species found after 1924 (Nikolin 2014); an aggressive segetal weed; Mag: IS 4; an ephemerophyte, colonizes dumpsites, ruins, cabbage fields; individual plants were found in 2008 in Okhotsk, very rarely in Kolyma (in 1975 near Susuman and near Kolymskoye village) (Lysenko 2012).

\section{APIACEAE}

\section{Aegopodium podagraria L.}

Distribution in Asian Russia: Al, GA, Ha, Ke, Kr_Ve, $\mathrm{Ku}, \mathrm{No}, \mathrm{Om}, \mathrm{Tm} \_\mathrm{Tb}$, To.

Prim: IS 2; common (Kozhevnikov \& Kozhevnikova 2011); Sakh: IS 2-3; cultivated on Kunashir Island (Fukuda et al. 2014); in the neighborhood of Yuzhno-Sakhalinsk, it escapes from the culture and invades the disturbed habitats: abandoned agrocenosis, forest edges; Khab: IS ?; recently has become a popular ornamental plant in the south, occurs along ditches and in roadside areas in garden associations (Antonova 2018); Kam: IS 4; occurs in residential areas in the city of Petropavlovsk-Kamchatsky and in Paratunka town; in all cases forms the monodominant communities suppressing natural vegetation; potentially invasive species (Chernyagina \& Devyatova 2018).

\section{Carum carvi $\mathrm{L}$.}

Distribution in Asian Russia: Al, Bu, Ch_Ka, Ch_Sh, $\mathrm{Da}, \mathrm{E} \_\mathrm{Al}, \mathrm{GA}, \mathrm{Ha}, \mathrm{Ir} \_\mathrm{An}, \mathrm{Ir} \_\mathrm{Pr}, \mathrm{Ka}, \mathrm{Ke}, \mathrm{Kr} \_\mathrm{TN}, \mathrm{Kr} \_\mathrm{Ve}$, $\mathrm{Ku}, \mathrm{LZ}, \mathrm{NB}, \mathrm{No}, \mathrm{Ok}, \mathrm{Om}, \mathrm{SB}, \mathrm{SK}, \mathrm{SS}, \mathrm{Tm} \_\bar{H} M, \mathrm{Tm}_{-} \mathrm{Tb}$, To, Ty, Us, Yk_Al, Yk_Vi.

Prim: IS 2-3; occurs along railroad tracks, on dumpsites, waste grounds, around buildings; reported from trampled clearings in forest margins of floodplain forests; Sakh: IS 3; mentioned for the Western Sakhalin montane area, Lamanon Coastal area and Poronaisky District (Barkalov \& Taran 2004); Khab: IS 2; first reported from Selikhino station of Komsomolsky District (Schlotgauer \& Schroeter 1969); forms thickets on crushed stony substrate, is a part of ruderalized meadows, reported from forest margins close to populated areas; in the northeast successfully naturalizes (Antonova 2012, Vinogradova et al. 2018); Jew: IS 2; Amur: IS 3; Yak: IS 4; included in the list of species found after 1926 (Nikolin 2014); occurs quite rarely, in central and southern areas, on meadows, in forest margins, on steppe slopes, in fallow fields and along the pebble roads; Mag: IS 3; an epecophyte, occurs on artificial artificial artificial meadows, waste grounds, in roadside areas, on lawns; rarely in Okhotsky FD (Magadan and surroundings, Ola, Talon, Arman, Splavnaya towns), very rarely in 2007 in OkhotskKolyma FD (town of Talaya), in Kolyma FD (town of Orotukan; as individual plants in 2008, near the Matrosov town) (Lysenko 2012); Kam: IS 3; occurs everywhere in disturbed areas (Chernyagina \& Devyatova 2018).

\section{Heracleum sosnowskyi Manden.}

Distribution in Asian Russia: Ka, SS.

Sakh: IS 1; reported for the Southern Sakhalin Plain (Barkalov \& Taran 2004); now an agressive species, which spreads along the roads in Southern Sakhalin Plain, forming dense thickets; invades the meadows and derivative forest communities; Kam: IS 1; occurs in Yelizovo District, an agriophyte (Chernyagina \& Shtreker 2012, Abramova et al. 2017, Chernyagina \& Devyatova 2018); introduced for silage crop in the fields of Kamchatka agricultural experimental station in the town of Sosnovka; nowadays, the species covers large areas on warm soils next to swimming pools, bore holes and pipelines of recreation facilities in the valley of the Paratunka River, and on lawns in neighbouring villages; the species was first reported in PetropavlovskKamchatsky in 2010, where it naturalized near the heating pipe systems; it spreads along roadsides and along the courses of ditches and streams; in 2015, it was reported on the slope of a mud volcano $3 \mathrm{~km}$ away from the initial invasion spot; in 2018, it was first reported in the city of Vilyuchinsk; in all instances, the plants prefer well lit and warmed areas.

\section{Pastinaca sylvestris Mill.}

Distribution in Asian Russia: Al, GA, Ir_An, Ke, Kr_Ve, $\mathrm{Ku}, \mathrm{No}, \mathrm{Om}, \mathrm{SB}, \mathrm{Tm} \_\mathrm{Tb}$, To, Us.

Prim: IS 3; a common species, grows along roads, in the streets in populated areas, along railway tracks, sometimes occurs in large numbers; Khab: IS 1; in the southern part, massively spreads in the roadside areas of automobile roads and railways, colonizes margins of broad-leaved forests (Antonova 2012); Jew: IS 1; Amur: IS 4; Bur: IS 4; in the south is a potentially invasive species; Yak: IS ?; known from one spot (estuary of the Khalamanda River), floodplain meadow (Cherosov 2012).

\section{Pimpinella saxifraga $\mathrm{L}$.}

Distribution in Asian Russia: Al, GA, Ha, Ka, Ke, Kr_ Ve, Ku, No, Om, SB, Tm_HM, Tm_Tb, To, Ty, Us.

Prim: IS 3; occurs rarely, is common along railway tracks; Khab: IS 3; in southern part of the seashore; Amur: IS ?; almost does not invade seminatural and natural communities; Mag: IS 3; a colonophyte, reported from fallow fields, roadsides and lawns; in Okhotsky FD is rare (near the town of Sokol, near the town of Splavnaya, Magadan) (Lysenko 2012); Kam: IS ?; indicated as an alien plant in old collections, in roadsides (Pimenov 1987).

\section{ASTERACEAE}

\section{Achillea millefolium $\mathrm{L}$.}

Distribution in Asian Russia: Al, Am, Bu, Ch_Ka, Ch $\mathrm{Sh}, \mathrm{Da}, \mathrm{GA}, \mathrm{Ha}, \mathrm{Ir} \_\mathrm{An}, \mathrm{Ir} \_\mathrm{Pr}, \mathrm{Ka}, \mathrm{Ke}, \mathrm{Kr} \_\mathrm{Pu}, \mathrm{Kr} \mathrm{TN}_{\mathrm{T}}$ $\mathrm{Kr} \_\mathrm{Ve}, \mathrm{Ku}, \mathrm{LZ}, \mathrm{NB}, \mathrm{No}, \mathrm{NS}, \mathrm{Ok}, \mathrm{Om}, \mathrm{SB}, \mathrm{SS}, \mathrm{Tm} \_\mathrm{HM}$, Tm_Tb, To, Ty, Us, Yk_Vi.

Prim: IS 2: first reported by Vorob'ev (1954), "Yarrow very rapidly colonized the [Primorsky] area, now it occurs in many districts along roads and trails, in the places of intensive pasture and thinned hazel coppices (for example, near the village of Osinovka of Mikhailovsky District)"; currently grows in roadsides, on railway embankments, waste grounds, grazing grounds; in the northern part of the area (near the village of Amgu) it is observed as solid thickets on seashore meadows; Sakh: IS 3; reported from nearly all districts of the central and southern Sakhalin (Barkalov \& Taran 2004); Khab: IS 3; colonizes disturbed and semidisturbed forest and meadow communities, artificial forests; (Antonova 2012); Jew: IS 3; active on abandoned fields, meadows; Amur: IS 3; an epecophyte, occurs in roadsides, on railway embankments, waste grounds (Aistova 2009); Yak: IS ?; a native species of natural graminoid communities, which easily colonizes disturbed landscapes in populated areas, kitchen gardens, fallow fields (Nikolin 2016); Mag: IS 2; an agriophyte; colonizes artificial meadows, fallow fields, roadside areas, lawns, floodplain meadows; rare in Okhotsky FD, very rare in Okhotsk-Kolyma FD (town of Stekolny, near the town of Talaya), rare in Kolyma FD (Lysenko 2012); Kam: IS 3; occurs in populated areas of Yelizovo, 
Milkovo, Ust-Bolsheretsk, Tigil and Karaga Districts (Chernyagina \& Devyatova 2018); Chuk: IS ?; rare, near the village of Beringovsky (anthropogenic meadow in the seaport).

\section{Ambrosia artemisiifolia $\mathrm{L}$.}

Distribution in Asian Russia: Ku, Us.

Prim: IS 1; reported for the first time in 1963 (Kudryavtseva et al. 2018), at present, broadly occurs in populated areas, roadsides, on waste grounds and in fallow fields, on railway embankments, in crops; penetrates into disturbed meadows, floodplain forests and river pebble deposits; Sakh: IS 1; reported from Southern Sakhalin Plain (Barkalov \& Taran 2004); Khab: IS 1; invades ruderal habitats and disturbed meadows in southern areas (Antonova 2012); in the last five years massively colonized the outskirts of Khabarovsk City; Jew: IS 1; rare in former time (Aistova et al. 2014, Kozhevnikov \& Kozhevnikova 2011), rapidly spreaded nowadays in whole region; most active in the area adjacent to the border with China, but individual plants are reported also in the city of Birobidzhan; Amur: IS 1; a colonophyte, reported for the first time by Nechaev (1998) and later by Starchenko (2001) from Arkhara District; collected again in 2004 on a railway embankment in the town of Kundur of Arkhara District (Aistova 2009); Mag: not in the list of invasive species, occurs as an ephemerophyte on landfills; very rare in Okhotsky FD (near Magadan) (Lysenko 2012).

\section{Arctium lappa L.}

Distribution in Asian Russia: Al, GA, Ke, $\mathrm{Kr}_{-} \mathrm{Ve}, \mathrm{Ku}$, LZ, No, SK, SS, Tm_Tb, Us.

Prim: IS 2; in populated areas, on dumpsites, in roadsides, regularly observed in floodplain forests, penetrates into moist and wet forests, forest margins and clearings; Sakh: IS 3; mentioned in the Schmidt Peninsula and several districts of the southern part of Sakhalin Island (Barkalov \& Taran 2004); widespread on Kuril Islands (Kunashir and Iturup Islands) (Fukuda et al. 2014); Khab: IS 4; colonizes mostly ruderal nitrogen-rich habitats, rarely occurs in the margins of floodplain and broad-leaved forests not far from roads; Kam: IS 4; occurs rarely in Ust-Kamchatsk and Yelizovo Districts (Chernyagina \& Devyatova 2018).

\section{Arctium tomentosum Mill.}

Distribution in Asian Russia: Al, GA, Ha, Ir_An, Ir_Pr, $\mathrm{Ke}, \mathrm{Kr} \_\mathrm{Ve}, \mathrm{Ku}, \mathrm{LZ}, \mathrm{No}, \mathrm{NS}$, Om, SK, SS, Tm_HM, Tm_ Tb, To, Ty, Us, Yk_Vi.

Prim: IS 2; grows in populated areas, on waste grounds, in roadsides, also reported from floodplain forests; Sakh: IS 3; reported from the Shmidt Peninsula, some districts of the central and southern Sakhalin (Barkalov \& Taran 2004), is common on Kuril Islands (Kunashir and Iturup Islands) (Fukuda et al. 2014); Khab: IS 4 (Antonova 2012); Jew: IS 3; Amur: IS 2; an epecophyte; first found in Arkhara District in 1982 and in 1985 by Yashchenkova and Yakubov (VLA) on dump sites, along railway embankments, next to dwellings; currently occurs in ruderal habitats in Blagoveshchensk District (Aistova 2009); Yak: IS 3; known from 1926 (Komarov 1926); Karavaev (1958) cited it as an alien plant in central Yakutia; occurs rarely, a large overgrown area was reported in a fallow field near the city of Lensk; potentially aggressive weed species (Nikolin 2016); Mag: IS 3; a colonophyte, on artificial meadows, near fences, on landfills; very rare in Okhotsky FD (near Magadan, town of Talon) (Lysenko 2012); Kam: IS 3; occurs in ruderal habitats: next to dwellings, along roads, on lawns in central and southern districts (Chernyagina \& Devyatova 2018).

\section{Artemisia annua L.}

Distribution in Asian Russia: Al, Bu, Ch_Sh, Ha, Ir_An, Kr_Ve, LZ, SB, Ty, Us.
Prim: IS 2; in roadsides, on dumpsites, waste grounds, kitchen gardens, grazing grounds, in fields, along railway tracks; penetrates into the mud, sand and pebble deposits along rivers, and occasionally even floodplain forests; Khab: sporadically occurs on lawns, in roadside areas, not an invasive species.

\section{Artemisia sieversiana Ehrh.}

Distribution in Asian Russia: Al, Am, Bu, Ch_Sh, Da, GA, Ha, Ir_An, Ir_Pr, Ka, Ke, Kr_Ve, Ku, LZ, NB, Ni, No, Ok, Om, SB, Tm_HM, Tm_Tb, To, Ty, Us, Yk_Al, Yk_Vi.

Prim: IS 3; an abundant plants, occur along the streets of populated areas, in roadsides, on waste grounds, dumpsites, in fallow fields, crops, on the seashore; Khab: IS 4; an abundant plants, colonize open habitats, which are not colonized by other species, may form monodominant communities, but do not withstand competition; Yak: IS ?; known from the central, southern and northeastern regions of Yakutia, is rarely introduced to the Arctic; grows on steppe slopes, ploughland, in fallow fields and as a weed in populated areas; occasionally forms large, almost monodominant communities (Nikolin 2016); Mag: IS 3; an epecophyte, occurs in fallow fields, on lawns, in kitchen gardens, artificial meadows, near fences; rare in Okhotsky FD (village of Gadlya, in 1975, in Magadan), Kolyma FD (town of UstOmchug, village of Verkhny Seimchan) (Lysenko 2012); Kam: IS 4; occurs in ruderal habitats in Ust-Kamchatsk and Bystrinsky Districts (Chernyagina \& Devyatova 2018).

\section{Artemisia vulgaris $\mathrm{L}$.}

Distribution in Asian Russia: Al, Bu, Ch_Ka, Ch_Sh, $\mathrm{Da}, \mathrm{GA}, \mathrm{Ha}$, Ir_An, Ir_Pr, $\mathrm{Ka}, \mathrm{Ke}, \mathrm{Kr} \_\mathrm{Pu}, \mathrm{Kr} \mathrm{T}_{-} \mathrm{Ta}, \mathrm{Kr}{ }_{-} \mathrm{TN}$, $\mathrm{Kr} \_\mathrm{Ve}, \mathrm{Ku}, \mathrm{LZ}, \mathrm{NB}, \overline{\mathrm{Nj}}$, No, NS, Ok, Om, SB, SS, Tm HMm, Tm_Tb, Tm_Ya, To, Ty, Us, Yk_Al, Yk_Ko, Yk_Ol, Yk_Vi, Yk_Ya.

Prim: almost does not invade seminatural and natural communities; Sakh: IS 2-3; reported from several districts of central and southern Sakhalin, where it invades the meadows (Barkalov \& Taran 2004); now spreads in disturbed habitats and natural shrub communities along the coast of the Nevelskoy Strait; Khab: possibly a native species; Amur: IS 4; a colonophyte, occurs in Skovorodino, Zeya, Blagoveshchensk, Bureisky and Konstantinovsky Districts, in roadsides (Aistova 2009); Yak: IS ?; in central and southern areas in roadside areas, next to dwellings, in fallow fields; Mag: IS 3; an epecophyte, colonizes artificial meadows, roadsides, fallow fields, lawns, waste grounds; a weed in the crops of annual grasses, on gold mining tailings; frequently in Okhotsky and Kolyms FD (Lysenko 2012); Kam: IS 3 for Bystrinsky and Milkovo Districts; IS 4 in Yelizovo and Ust-Kamchatsk Districts (Chernyagina \& Devyatova 2018).

\section{Aster novae-angliae $\mathrm{L}$.}

\section{Distribution in Asian Russia: Us.}

Prim: IS 2-3; reported from abandoned garden, spreads along roads, invades disturbed scrub communities; Sakh: IS 3; Khab: grown as an ornamental plant, differs well from other species by large flower heads with purple ray florets and abundant hairs with glandular hairs; sometimes grows close to the areas where it is cultivated, is not included in the list of invasive species.

\section{Aster novi-belgii L.}

Distribution in Asian Russia: SK, SS, Us.

Prim, Sakh, Khab: IS 3; which escapes from culture forming persistent groups in ruderal habitats, along railway tracks, in road ditches, on waste grounds. 


\section{Bidens frondosa $\mathrm{L}$.}

\section{Distribution in Asian Russia: Bu, LZ, SK, Us.}

Prim: IS 1; explosive spread of this species was observed on the islands of the Peter the Great Bay in bird colonies and security cordons (Chubar 2015); occurs often along roads, on dumpsites, in kitchen gardens; abundant on river pebble, recently it has been regularly reported from floodplain forests, less often from the banks of water bodies, wetlands, meadows, moist forests (Alnus japonica), among rocks; Sakh: IS 2; reported for Kunashir Island (Barkalov 1992); Khab: IS 1; invades rills, road ditches, floodplains of small rivers (Antonova 2012); Jew: IS 1; Amur: IS 2; an epecophyte, first mentioned by Starchenko (2001); reported from Arkhara, Tambovsky, Ivanovo, Blagoveshchensk, Belogorsk Districts (Aistova 2009).

\section{Carduus acanthoides $\mathrm{L}$.}

\section{Distribution in Asian Russia: Bu, Us.}

Prim: IS 2; found by Vorob'ev in 1951 on river pebble deposits and in willow stands near Anisimovka railway station, along Partizanskaya (Suchan) River, in 1952 - in village Kishinyovka and in the floodplain of the Kievka River, and in 1962 - in large numbers in the city of Vladivostok (Vorob’ev 1954 (as Cirsium nutans L.), 1964); Khab: IS ?; occurs as individual plants or in small groups exclusively in secondary habitats in populated areas.

\section{Cirsium setosum (Willd.) M. Bieb.}

Distribution in Asian Russia: Al, Am, Bu, GA, Ha, Ka, $\mathrm{Ke}, \mathrm{Kr} \_\mathrm{TN}, \mathrm{Kr} \_\mathrm{Ve}, \mathrm{Ku}, \mathrm{LZ}, \mathrm{NK}, \mathrm{No}, \mathrm{NS}, \mathrm{Ok}, \mathrm{Om}, \mathrm{SK}, \mathrm{SS}$, Tm_HM, Tm_Ya, To, Ty, Us, Yk_Al.

Prim: IS 1; actively colonizes waste grounds, fields, kitchen gardens, banks of water bodies; according to Vorob'ev (1954, cited as C. arvense), it is one of the most persistent weeds of the Far East, spreads deep in forest areas, where it colonizes not only pebble deposits, but also landslides and cliffs, and sometimes burnt forest areas; nowadays, it is an abundant species occurring in fields, kitchen gardens, along roads, in fallow fields and regularly found in forest margins and clearings; it also reported from shrub communities, Alnus japonica forests, on meadows; Sakh: IS 2-3; reported from the Shmidt Peninsula and some districts of the central and southern Sakhalin (Barkalov \& Taran 2004); Khab: IS 2; a common segetal and ruderal species occupying various secondary habitats, rapidly colonizes disturbed natural communities, meadows, shrub communities, forest margins (Antonova 2012); Jew: IS 1; reported everywhere along roads, on dumpsites; Amur: IS 3; an epecophyte, an abundant weed, occurs in forest margins and on felling sites, along river shores, in roadside areas, fallow fields, on railway embankments, in the fields and kitchen gardens (Aistova 2009); Yak: IS ?; probably a native meadow and steppe species acting as an aggressive segetal weed, spreading widely to the habitats disturbed by humans, including also populated areas (Nikolin 2016); Mag: IS 3; an epecophyte; occurs in roadside areas, on artificial meadows, waste grounds, lawns, in fallow fields, and on gold mining tailings; rare in Okhotsky FD, very rare in Okhotsk-Kolyma FD (town of Talaya), rare in Kolyma FD (town of Spornoye, Orotukan, Sinegorye, in 1988 found near Susuman) (Lysenko 2012); Kam: IS 3; occurs everywhere, actively forms communities in roadside areas, on waste grounds, landfills, in fallow fields (Chernyagina \& Devyatova 2018).

\section{Conyza canadensis (L.) Cronq.}

Distribution in Asian Russia: Al, Am, Bu, Ch_Sh, Ha, Kr_Ve, Ku, LZ, No, SK, SS, Tm_Tb, Us.

Found in the south of the Russian Far East in 1902. By the mid 20th century became a common weed in Primorsky
Territoty, in the south of Amur Region and the southern part of Sakhalin and Kuril Islands shaping the eastern part of the species range (Vinogradova 2005, Vinogradova et al. 2011).

Prim: IS 2; a common species, widespread in roadsides, fields, fallow fields, artificial meadows, grazing grounds, populated areas, penetrates into mud, sand and pebble deposits along rivers and the seashore, reported also from floodplain forests; Sakh: IS ?; reported from almost all districts of Sakhalin (Barkalov \& Taran 2004); Khab: IS 2 (Antonova 2012); Jew: IS 2; Amur: IS 2; an epecophyte, occurs next to dwellings, in fallow fields, on meadows, river pebble deposits, in roadsides, along trails and forest roads, in agricultural crops (Aistova 2009); Bur: IS 4 (in southern districts); first collected in 1990 (Ivanova 1991), nowadays belongs to potentially invasive species; Zab: not included in the list of invasive species (Ebel et al. 2016); Yak: IS ?; first mentioned by Komarov (1926) on the basis of old herbarium collections, without the indication of the precise position and storage place of the herbarium specimens.

\section{Crepis tectorum $\mathrm{L}$.}

Distribution in Asian Russia: Al, Am, Bu, Ch_Ka, Ch Sh, Da, E_Al, GA, Ha, Ir_An, Ir_Pr, Ka, Ke, Kl, Kr_TN, Kr_Ve, Ku, LZ, NB, No, NS, Ok, Om, SB, Tm_Tb, To, Ty, Us, UZ, Yk_Al, Yk_Vi, Yk_Ya.

Prim: IS 2; in many districts on river pebble deposits (Vorob'ev 1954); nowadays, occurs along roads, on grazing grounds, in fields, fallow fields, on sandy seashore, railway embankments; Sakh: IS ?; reported for almost all districts of Sakhalin (Barkalov \& Taran 2004); Khab: IS ?; introduced long before now and well naturalized (possibly native), almost does not invade seminatural and natural communities (Antonova 2012), but occurs in large range of various types of secondary habitats; Amur: IS 3; an epecophyte, a prevalent species; occurs in roadsides, on waste grounds, river pebble deposits, dry meadows, in fields and on railway embankments (Aistova 2009); Yak: probably a native meadow and steppe species acting as an aggressive weed at farmsteads, on waste grounds, in kitchen gardens, on ploughland, in fallow fields (Nikolin 2016); Mag: IS 2; an agriophyte, colonizes roadside areas, waste grounds, artificial meadows, fallow fields, landfills, gold mining tailings, river pebble deposits, sand and mud loads along river shores, floodplain willow stands and meadows, sedge fens, screes along roads; rare in Okhotsk FD, frequently in continental areas (Lysenko 2012); Kam: IS 4; an epecophyte, does not form communities (Chernyagina \& Devyatova 2018).

\section{Cyclachaena xanthiifolia (Nutt.) Fresen.}

Distribution in Asian Russia: Bu, Us.

Prim: IS ?; almost does not invade seminatural and natural communities; Khab: IS ?; occurs rarely as individual plants, most frequently next to railway stations, almost does not invade seminatural and natural communities (Antonova 2012); Jew: IS 2; in the south of the oblast forms solid stands up to $2 \mathrm{~m}$ nigh next to cattle-yards, in abandoned kitchen gardens; reported from populated areas near the Amur River, especially active on the territory of abandoned farms; reaches large size; Amur: IS 3; an epecophyte, first mentioned by Starchenko (2001); in 2002, 2003, 2005, new locations were found in the city Blagoveshchensk and Konstantinovsky District (villages Konstantinovka and Novopetrovka); in the places where the species was introduced it is sustainable and tends to spread further (Aistova 2009).

\section{Galinsoga quadriradiata Ruiz \& Pav.}

Distribution in Asian Russia: Bu, Us.

Prim: IS 2; an abundant species in populated areas (Vladivostok, Nakhodka), common in the streets, on waste 
grounds, in flowerbeds, kitchen gardens, on dumpsites, penetrates into floodplain forests; Khab: IS 3; Jew: IS 3.

\section{Galinsoga parviflora Cav.}

Distribution in Asian Russia: Al, LZ, No, SK, Us.

Prim: IS 2; in the streets of populated areas, on waste grounds, flowerbeds, in kitchen gardens, often penetrates river pebble deposits; Sakh: IS ?; occurs on Kunashir Island (Fukuda et al. 2014); Khab: IS 1; rapidly spreads in kitchen gardens and ploughland, invades disturbed shrub communites, forest margins, floodplain complexes of small rivers (Antonova 2012); Jew: IS 1; reported mostly in seminatural cenoses, in populated areas; Amur: IS 3; an epecophyte, occurs in large numbers in kitchen gardens, on waste grounds, in flowerbeds, parks (Aistova 2009).

\section{Helianthus tuberosus L.}

Distribution in Asian Russia: Al, Ch_Sh, GA, Ha, Ir An, Ke, Kr_Ve, Ku, No, Om, SB, Tm_Tb, To, Ty, Yk_Al, Yk_Vi.

Prim: IS ?; within the boundaries of gardening allotments often escapes from culture; Sakh: IS 4; reported for the districts of southern Sakhalin (Barkalov \& Taran 2004); Khab: IS 2; invades the communities of ruderal habitats and disturbed meadows, persists for a long time on forest clearings, where this species was planted for feeding the game animals (Antonova 2012); Jew: IS 2; Amur: IS 3; Bur, Zab: not included in the Black Book (Ebel et al. 2016); Kam: IS 3-4; reported in ruderal habitats in Milkovo and Bystrinsky Disricts (central Kamchatka), with that in Bystrinsky Disricts it does not enter herbs meadows next to a warm streams (Chernyagina \& Devyatova 2018).

\section{Lactuca serriola $\mathrm{L}$.}

Distribution in Asian Russia: Al, Ke, Ku, LZ, No, Om, Tm_Tb, Ty, Us.

Prim: IS 2; initially collected in 1972 in Vladivostok; recently has spread in large numbers across man-made habitats: in the streets of populated areas, on lawns, in roadsides, on road slope sides and in ditches, on railway embankments, in fields, open pits; one of the pioneers in colonizing bare soil; invaded river pebble deposits along the bank of Khanka Lake in Khankaisky Nature Reserve (specimens in VLA); Sakh: IS 3; reported for Southern Sakhalin Plain (Barkalov \& Taran 2004); Khab: IS 4; initially found in Khabarovsk in 1984; in the end of the 20th century spreaded massively to secondary habitats in the south of the Territory; nowadays, the boundary has shifted $400 \mathrm{~km}$ northward, but the species occurs less frequently and does not penetrate into the natural phytocenoses.

\section{Leontodon autumnalis $\mathrm{L}$.}

Distribution in Asian Russia: $\mathrm{Al}, \mathrm{Am}, \mathrm{Bu}, \mathrm{Ha}, \mathrm{Ir} \_\mathrm{An}$, Ir_Pr, Ka, Ke, Kr_Pu, Kr_Ve, Ku, LZ, NK, No, NS, SB, SK, SS, Tm_Tb, To, Us.

Prim: IS 3; along roads, next to dwellings, on railway embankments, grazing grounds, waste grounds; Sakh: IS 3; indicated for all districts of Sakhalin (Barkalov \& Taran 2004), a prevalent naturalized species on Kuril Islands (Shikotan, Kunashir and Iturup) (Fukuda et al. 2014); Khab: IS 3; mostly widespread in the coastal areas (Antonova 2012); Amur: IS 4; a colonophyte, only one location is known near the town of Ekimchan of Selemdzha Districts on pebble tailings left from gold mining (collected by Yakubov, 1992 and Aistova, 2002); Kam: IS 3; a prevalent species that occurs in disturbed habitats (Chernyagina \& Devyatova 2018).

\section{Lepidotheca suaveolens (Pursh) Nutt.}

Distribution in Asian Russia: Al, Am, AP, Co, Da, E_Al, GA, Ha, Ir_An, Ir_Pr, Ka, Ke, Kl, Kr, Kr_Ve, Ku, LZ, NB, NK, No, NS, Ok, Om, SB, SK, SS, Tm_HM, Tm_Tb, To, Ty, Us, UZ.

Prim: IS 2; a prevalent species, occurs in the streets of populated areas, along roads, on grazing grounds and other trampled areas, penetrates into the river pebble deposits; Sakh: IS 3; mentioned in almost all districts of Sakhalin (Barkalov \& Taran 2004), a prevalent naturalized species on Kuril Islands (Shikotan, Kunashir and Iturup) (Fukuda et al. 2014); Khab: IS 2; naturalized in region long ago and spreaded across the Territory, but everywhere it occupies ruderal and moderately trampled habitats, colonizes well fertilized soils of graing grounds, next to farmsteads, forms a solid cover; less frequently occurs in small groups in secondary habitats of other types; no trends for further expansion have been indicated; not included in the regional list of invasive species; Bur: IS 2; Zab: not included in the list of invasive species (Ebel et al. 2016); Yak: IS 3; first mentioned by Karavaev (1958) as a rare weed; potentially dangerous and aggressive species; insignificant trends for the expansion of the species in the central and southern districts are observed, mainly as a ruderal and pasture weed (Nikolin 2014, 2016); Mag: IS 2; an agriophyte; waste grounds, roadside areas, trampled artificial meadows, kitchen gardens, fallow fields, dumpsites, gold mining tailings, river pebble deposits, coastal cliffs with bird colonies; frequently in all districts, except for the east of region, where it is rare (Lysenko 2012); Kam: IS 3; occurs in all districts, forms communities on trampled areas, enters disturbed thermal grounds next to hot springs (Chernyagina \& Devyatova 2018); Chuk: IS ?; town of Provideniya, catchment area of the Anadyr River (town of Markovo), Koryak Upland and coast (towns of Alkatvaam, Meinypilgyno and Beringovskiy); along roads, in populated areas, less frequently on riverside sands and pebble deposits.

\section{Phalacroloma annuum (L.) Dumort}

(incl. Ph. strigosum (Muehl. ex Willd.) Tzvelev)

\section{Distribution in Asian Russia: Bu, SK, SS, Us.}

Prim: IS 1; reported long ago by Vorob'ev (1954: "Over the past 10-15 years [i.e. since around 1939 until 1954] annual fleabane has spread very broadly throughout the [Primorsky] Territory; it penetrated from fallow fields and dumpsites into gramineos-grass meadows and thinned hazel and Lespedeza shrub stands. Today, this species can be found in many districts of the region. During flowering, it sometimes even creates aspect"; currently it is an abundant species, growing in fallow fields, along roads, on waste grounds, grazing grounds, in populated areas. Actively penetrates forest margins and clearings, fire-breaks, sometimes reported in floodplain forests and on river pebble deposits; Sakh: IS 3; reported for the southwestern part of Sakhalin (Barkalov \& Taran 2004); Khab: IS 3; actively colonizes roadsides, areas along railway tracks; Jew: IS 4; Amur: IS 4; included in the group with status 4 , however, in 2018 it was found on the pebble bank of the Bureya River downstream from Bureya hydropower station.

\section{Pilosella aurantiaca (L.) F. Schultz et Sch. Bip.}

Distribution in Asian Russia: Al, Ka, NK, NS, SS, To.

Sakh: IS 1-2; common on Kuril Islands (Kunashir Island, Iturup Island) (Fukuda et al. 2014) and mentioned almost for all districts of Sakhalin (Barkalov \& Taran 2004); common in the south of the island, actively penetrates into the meadow communities (Andreeva 2014) and forest plantations; abundance of this species decreases gradually 
from the maximum in 1970s; Khab: IS ?; has a limited distribution, first found in 2006; another species, P. floribunda (Wimm. et Grab.) Fries, is more active in Territory; it grows not only in roadsides but also in the margins of smallleaved forests; Kam: IS 2; occurs in Sobolevo and Yelizovo Districts, not only in disturbed habitats and on lawns but also on meadowy slopes of mud volcanos (Chernyagina \& Devyatova 2018).

Rudbeckia hirta L.

(incl. R. bicolor Nutt.).

Distribution in Asian Russia: Ir_An, SK, To, Us.

Prim: IS ?; known from a limited number of habitats, but intensively naturalizes on Reineke Island (Peter the Great Bay); Sakh: IS 3; occurs on Kunashir Island (great numbers in the estuary of the Tyatina River) (Fukuda et al. 2014); Khab: cultivated, rarely goes in wilderness.

\section{Senecio viscosus $\mathrm{L}$.}

Distribution in Asian Russia: Kr_Ve, SS, Tm_Tb, Us.

Prim: IS 2-3; common species in populated areas, also occurs in roadside areas, on rock dumps, railway embankments, penetrates under the canopy of oak forests in stony areas and seashore pebble deposits; Sakh: IS ?; mentioned for the southwestern area of Sakhalin (Barkalov \& Taran 2004); Khab: IS 4; first mentioned in the collections of Voroshilov near the city of Khabarovsk; by the end of the 20th century became a common species especially in towns Sovetskaya Gavan and Vanino, the industrial and transport hubs; currently occurs far from populated areas along logging roads.

\section{Senecio vulgaris $\mathrm{L}$.}

Distribution in Asian Russia: Al, Am, Ch, Da, Ha, Ir An, Ir_Pr, Ka, Ke, Kr, Kr_TN, Kr_Ve, Ku, NB, NK, No, Ok, SB, SK, SS, Tm_Tb, To, Ty, Us, UZ, Yk_Al, Yk_Vi.

Prim: IS 2-3; everytope species, occurs along railway tracks, on waste grounds, in kitchen gardens, on dumpsites, also penetrates into the pebble, mud and sand river deposits; Sakh: IS ?; reported for almost all districts of Sakhalin (Barkalov \& Taran 2004), occurs on Shikotan and Iturup Islands (Fukuda et al. 2014); Khab: first introduced in the mid 19th century and occupied all suitable ecological niches, demonstrates no trends of invasion to seminatural and natural communities; Amur: IS 3; Bur, Zab: IS 4 (Ebel et al. 2016); Yak: IS 3; included in the list of species found before 1926 (Komarov 1926, Nikolin 2014); common in central and southern areas on waste grounds, landfills, next to dwellings, along roads, on ploughland and in fallow fields (Nikolin 2014, 2016); Mag: IS 3; an epecophyte, colonizes kitchen gardens, potato fields, ditches, waste grounds, landfills, roadside areas, felling sites (Lysenko 2012); Kam: IS 4; occurs sporadically, in disturbed habitats, in Karaga District reported from the seashore sands (Chernyagina \& Devyatova 2018); Chuk: IS ?; town Provideniya; weed species.

\section{Solidago gigantea Ait.}

\section{Distribution in Asian Russia: Ka, SK, SS, Us.}

Prim: IS 1; cultivated and goes in wilderness, reported next to dwellings, in roadside areas, as well as in floodplain and moist forests, in forest margins and in shrub communities, forms thickets; Sakh: IS 3; mentioned for the southwestern area of Sakhalin (Barkalov \& Taran 2004), occurs on Iturup Island, where it is reported from meadows along roads (Fukuda et al. 2014); Khab: IS ?; almost does not invade seminatural and natural communities, rarely cultivated (Antonova 2012); Kam: IS 4; introduced as an ornamental plant, occurs infrequently in southern and central districts (Chernyagina \& Devyatova 2018).

\section{Solidago canadensis $\mathrm{L}$.}

Distribution in Asian Russia: Al, Bu, Ka, No, SS, Us.

Prim: IS 1-2; escaped from culture, reported from sites along the roads, penetrates into floodplain and moist forests, common in shrub communities; Sakh: IS 2; mentioned for Southern Sakhalin Plain (Barkalov \& Taran 2004); begun to spread recently, occupies various secondary habitats, quickly colonizes disturbed natural communities, meadows, shrub communities and forest margins; Khab: IS 1; invades ruderal habitats, disturbed meadows, fruit tree plantations forming monodominant communities (Antonova 2012); Jew: IS 1; Amur: IS 4; rarely occurs in small sites if not cultivated; Kam: IS 4; introduced as an ornamental plant, occurs infrequently (in southern and central districts), colonophyte (Chernyagina \& Devyatova 2018).

\section{Sonchus oleraceus $\mathrm{L}$.}

Distribution in Asian Russia: Al, Ch_Sh, Da, GA, Ir_An, Ir_Pr, Ke, Kr_TN, Kr_Ve, Ku, No, Om, SB, SK, SS, Tm_ HM, Tm_Tb, To, Us, Yk_Al, Yk_Vi.

Prim: IS 2; occurs frequently in populated areas, in roadsides, on stony slopes and seashore pebble deposits; Sakh: IS ?; mentioned for the southeastern and southwestern districts, Southern Sakhalin Plain (Barkalov \& Taran 2004); Khab: IS ?; as a weed and in small groups along ruderal habitats, no expansion have been indicated; Yak: IS 1-2; known since 1958 from Karavaev (1958), where it was mentioned as a rare weed in the vicinity of the town of Tommot and in the valley of the Lena River from the town of Olekminsk and downstream (probably up to the Aldan River); nowadays, occurs quite frequently in the central and southern districts, in fields, kitchen gardens, fallow fields, on waste grounds, in roadsides of unpaved roads, including moist salty soils; highly aggressive weed species with the continuing expansion trend; Kam: IS ?; occurs rarely, only along the roads.

\section{Taraxacum officinale Wigg. s.1.}

Distribution in Asian Russia: Al, Am, Bu, Ch_Ka, Ch Sh, GA, Ha, Ir_An, Ir_Pr, Ka, Ke, Kr_Pu, Kr_Ta, Kr_TN, Kr_Ve, Ku, LZ, NB, NK, No, Om, SB, SK, SS, Tm_HM, Tm_Tb, Tm_Ya, To, Ty, Us, UZ, Yk_Al, Yk_Ar, Yk_Ko, Yk_Ol, Yk_Vi, Yk_Ya.

Prim: IS 2; an abundant species, prevalent in kitchen gardens, fallow fields, along roads, on waste grounds, in populated areas; reported from seashore sands and pebble deposits along rivers and streams, as well as from forest clearings and in forests (more frequently in floodplain and moist forests); Sakh: IS ?; reported from almost all districts of Sakhalin, where it invades the meadows (Barkalov \& Taran 2004), occurs on Kunashir and Iturup Islands (Fukuda et al. 2014); Khab: IS 4; an abundant synanthropic plant in seminatural communities may colonize only areas with open vegetation and stay for some time on felling sites, burnt forest areas and overgrowing fallow fields; Mag: IS 3; a colonophyte, very rare (Lysenko 2012); Kam: IS 3; an abundant synanthropic species; (Chernyagina \& Devyatova 2018).

\section{Tripleurospermum inodorum (L.) Sch.Bip. (= T. perforatum (Mérat) Laínz).}

Distribution in Asian Russia: Al, Am, Bu, Ch_Sh, GA, $\mathrm{Ha}$, Ir_An, Ir_Pr, Ka, Ke, Kr_Ve, Ku, LZ, No, NS, Ok, Om, SB, SK, SS, Tm_HM, Tm_Tb, Tm_Ya, To, Ty, Us, UZ, Yk_Vi. 
Prim: IS 2; occurs on the seashore, on sandy and pebble beaches in bays, on stony rockslides at the foot of cliffs, on weed-grown grass meadows in bird colonies; and in continental areas - on pastures and grazing grounds, in roadsids, on waste grounds, penetrates sand and pebble deposits along rivers; Sakh: IS 2; reported from almost all districts of Sakhalin (Barkalov \& Taran 2004); Khab: IS ?; a ruderal species that colonized large areas, almost does not invade seminatural and natural communities (Antonova 2012); Amur: IS 2; an epecophyte, occurs on meadows, in roadsides, on river banks, in crops, next to dwellings, in ruderal habitats, prevalent; Bur, Zab: IS 3 (Ebel et al. 2016); Yak: IS 3; first mentioned by Karavaev (1958) as cultivated and rare weed plant from the vicinity of the cities Yakutsk and Olekminsk; nowadays known from the lower Kolyma River (Cherosov 2012), where it colonizes waste grounds, mounds of earth along the walls of peasant's houses, roadside areas; along the Lena River enters southern and probably central Yakutia from Irkutsk Region (Tolmachev 1974); potentially dangerous and aggressive species (Nikolin 2016); Mag: IS 3; an epecophyte, colonizes roadsides, waste grounds, fallow fields, trampled man-made meadows, as a weed occurs in annual grass crops, on gold mining tailings (Lysenko 2012); Kam: IS 3; occurs only in ruderal habitats (Chernyagina \& Devyatova 2018); Chuk: IS ?; indicated for Markovo village (Yurtsev et al. 2010).

\section{Tussilago farfara $\mathrm{L}$.}

Distribution in Asian Russia: Al, Bu, GA, Ha, Ir_An, Ir_Pr, Ka, Ke, Kr_TN, Kr_Ve, Ku, NB, No, Ok, SB, SS, Tm_Tb, Tm_Ya, To, Us, Yk_Al.

Prim: IS 2-3; reported along railway tracks and roads, especially on mountain slopes; at the end of the 20th century according to evaluation by Nechaeva (1998) species was known from Vladivostok and harbour Vostochny and did not showed spreading beyond that area; nowadays, the species is common in the Territory (cities Vladivistok, Nakhodka, town Shkotovo), sometimes invades into open slopes along roads and rills with landslides; Sakh: IS 3; reported from the districts of the southern part of Sakhalin (Barkalov \& Taran 2004); started spreading in the 1970s; in most disturbed habitats; transforms the plant communities in the natural sanctuary "Yuzhno-Sakhalinsky Mud Volcano"; Khab: IS 3; has been reported as a species that escaped from culture since the beginning of the 21 st century; grows in wet grasslands, ditches, recently has occurred in disturbed broad-leaved forests next to garden allotments; Jew: IS 4; Yak: IS ?; first mentioned for central Yakutia by Komarov; Karavaev (1958) gave detail information on loamy habitat; cited from the only collection from the first half of the 19th century but herbarium specimen was in badly damaged; relatively recently was found on bare valley sites $10-15 \mathrm{~km}$ away from the estuary of the Pilka River (right tributary of the Lena River, southern Yakutia); included in the list of dangerous and aggressive weed elements in the flora of Yakutia (Nikolin 2016); Mag: IS ?; an epecophyte on weedgrown sandy seashore cliffs and beaches (Lysenko 2012); Kam: IS 3; common species along the roads, on lawns in the populated areas of the central and southern districts; reported in the north, in the village of Palana (Chernyagina \& Devyatova 2018).

\section{Xanthium albinum (Widd.) H. Scholz.}

Distribution in Asian Russia: Bu, Ok, Us.

Prim: IS ?; does not invade seminatural and natural communities; Khab: IS 2; invades ruderal habitats and disturbed meadows, on sandy and mud banks of the Amur River and its tributaries may dominate riverside plant aggregations; Jew: IS 2; common species in the outskirts of popu- lated areas, on wastelands, landfills (Antonova et al. 2015); Amur: IS 3; an ephemerophyte, first collected in 1995 г. by Kudrin (2004) in Arkhara District; in 2005, it was reported from Mikhailovsky District in soybean crops and at the edge of a field (Aistova 2009); Bur, Zab: not included in the Black Book (Ebel et al. 2016); Mag: an ephemerophyte (Lysenko 2012).

\section{Xanthium strumarium $\mathrm{L}$.}

Distribution in Asian Russia: Al, Bu, Ha, Kr_Ve, LZ, No, SS, Tm_HM, Tm_Tb, Us.

Prim (Xanthium strumarium subsp. sibiricum): IS 2; common in populated areas on dumpsites, waste grounds, along roads and on river pebble deposits (Prokopenko 2011); Sakh: IS ?; mentioned only for the southwestern area of Sakhalin Island (Barkalov \& Taran 2004); Khab: IS 2; invades ruderal habitats and disturbed meadows, on sandy and mud banks of the Amur River and its tributaries may dominate riverside plant aggregations; Jew: IS 2; Amur: IS 4; an epecophyte, first herbarium collections (by Maximowicz) was dated by 1856 (VLA); collected in the roadside in the village Tambovka of Tambovsky District (Aistova 2009); Mag: an ephemerophyte (Lysenko 2012).

\section{BALSAMINACEAE}

\section{Impatiens glandulifera Royle}

Distribution in Asian Russia: Bu, Ch_Sh, GA, Ka, SS, Us.

Prim: IS 1; in some places abundant; in populated areas along roads, on dumpsites, penetrates into river and stream pebble deposits, moist forests (particularly Alnus japonica forests) and wet meadows; Sakh: IS 3; reported for almost all districts of central and southern Sakhalin, mainly in ruderal habitats (Barkalov \& Taran 2004), found on Kuril Islands (Shikotan and Kunashir) (Fukuda et al. 2014); Khab: IS 1; invades rills, road ditches, floodplains of small rivers (Antonova 2012); Jew: IS 1; naturalizes in various phytocenoses; Amur: IS 3; Bur: IS 3; colonizes and naturalizes disturbed habitats; Zab: IS 4; potentially invasive species (Ebel et al. 2016); Kam: IS 1; reported only from the Kamchatka Peninsula, colonizes ruderal habitats (yards, ditches, roadside areas), in the vicinity of the cities Petropavlovsk-Kamchatsky and Yelizovo covers large areas on the slopes of mud volcanos in residential areas, areas along streams and under forest canopy (Chernyagina \& Devyatova 2018, Abramova et al. 2017).

\section{Impatiens parviflora DC.}

\section{Distribution in Asian Russia: Al, Bu, GA, LZ, Us.}

Prim: IS 2; an aggressive species; at the beginning of the 21 st century was found in Vladivostok, nowadays spreads massively and penetrates into the natural and slightly disturbed communities; Khab: IS 2; first found in the city of Khabarovsk (arboretum) in 1964, and it was the only place from where it was known for a long time (Kozhevnikova \& Kozhevnikov 2016); nowadays penetrates into the rills, secondary or disturbed forest communities with a thin shrub layer, floodplains of small rivers; Jew: IS 2; Amur: IS ?; in city of Blagoveshchensk (Starchenko et al. 2014).

\section{BORAGINACEAE}

\section{Echium vulgare $\mathrm{L}$.}

Distribution in Asian Russia: Al, GA, Ha, Ir_An, Ka, Ke, Kr_Ve, Ku, No, Om, SB, SK, SS, Tm_Tb, To, Us.

Prim: IS 3; prevalent in roadsides and on dumpsites. Massively spreads under overhead power lines and along oil and gas pipelines in Shkotovsky and Partizansky districts; Sakh: 
IS ?; mentioned for some districts of central and southern Sakhalin (Barkalov \& Taran 2004), in culture on Kunashir Island, goes in wilderness (Fukuda et al. 2014); Khab: very rare, cultivated as an ornamental plant; Kam: encountered once in Yelizovo District (at a path), a colonophyte (Chernyagina \& Devyatova 2018).

\section{Nonea rossica Stev.}

Distribution in Asian Russia: Al, Ch_Sh, GA, Ha, Ir_An, Ir_Pr, Ke, Kr_Ve, Ku, LZ, No, Ok, Om, SB, Tm_Tb, To, Ty, Us, Yk_Al.

Prim: IS 2; along roads, on pebble deposits, waste grounds and abandoned fields in Shkotovsky and Mikhailovsky Districts, continues to spread successfully (Vorob'ev 1954, 1964, as N. pulla (L.) DC., Nedoluzhko \& Likhachyova 1986, as N. pulla (L.) DC. subsp. rossica (Stev.) Soo); Khab: IS ?; individual plants were found in the city of Khabarovsk by Nebaikin in 1980s; Yak: IS ?; found in mid 1980s; occurs rarely, some locations were reported from central (city of Yakutsk) and southern districts; in abandoned kitchen gardens, fallow fields, roadside areas (Nikolin 2016); the area on which the localities were found in the vicinity of the city of Yakutsk was allotted for summer cottage construction (the species may disappear); potentially dangerous species; Mag: IS ?; a colonophyte, occurs in fallow fields, on lawns, as a weed in annual grass crops, on felling sites (Lysenko 2012).

\section{Symphytum caucasicum M. Bieb.}

Distribution in Asian Russia: Al, Ch_Sh, $\mathrm{Ka}, \mathrm{Ku}, \mathrm{SS}$, Tm_Tb, Us.

Prim: IS 2; widely cultivated in populated areas, recently (neighbourhood of the city of Nakhodka) has penetrated into the ruderal meadow and roadside shrub communities, margins of disturbed forests; Sakh: IS 4; cultivated in southern Sakhalin; Khab: IS 1; at the beginning of the 21st century was widely cultivated as an ornamental plant, during the past decade has colonized rills, abandoned flowerbeds, occurs in road ditches and forest margins close to populated areas; in favourable conditions forms monodominant communities; Kam: IS 2; reported from many districts, in Petropavlovsk-Kamchatsky spreads from the areas where it is cultivated not only to ruderal habitats but also to meadowy slopes of mud volcanos, invading natural communities; also common in the city of Yelizovo and neighbouring towns, in the north of the peninsula - in the town of Palana (Chernyagina \& Devyatova 2018).

\section{BRASSICACEAE}

\section{Armoracia rusticana Gaertn.}

Distribution in Asian Russia: Al, Bu, LZ, Ch_Sh, Ha, Ir_An, $\mathrm{Ka}, \mathrm{Ke}, \mathrm{Kr} \_\mathrm{Ve}, \mathrm{Ku}, \mathrm{No}, \mathrm{Ok}, \mathrm{Om}, \mathrm{SB}, \mathrm{SS}, \mathrm{Tm} \_\mathrm{Tb}$, To, Ty, Us.

Prim: IS 3; is cultivated, occurs as a wilding on wet weedgrown meadows near populated areas, along roads; Sakh: IS 3; reported from Tymsky District and Southern Sakhalin Plain (Barkalov \& Taran 2004); Khab: IS 3; invades ruderal meadow and shrub communities, margins of disturbed forests; Jew: IS 3; Amur: IS 3; Bur: IS 4; potentially invasive species; Zab: not included in the Black Book (Ebel et al. 2016); Mag: IS ?; colono- and epecophyte, colonizes artificial meadows, roadside areas, ruins, abandoned kitchen gardens, stream banks in populated areas (Lysenko 2012); Kam: IS 4; colonophyte, occurs in abandoned kitchen gardens, roadsides (Chernyagina \& Devyatova 2018).

\section{Berteroa incana (L.) DC.}

Distribution in Asian Russia: Al, Am, GA, Ha, Ir_An, $\mathrm{Ka}, \mathrm{Ke}, \mathrm{Kr} \_\mathrm{Ve}, \mathrm{Ku}, \mathrm{LZ}, \mathrm{No}, \mathrm{Ok}, \mathrm{Om}, \mathrm{SB}, \mathrm{SS}, \mathrm{Tm} \_\mathrm{Tb}$, To, Ty, Us, Yk_Al.
Prim: IS 3; on railway embankments, in fields, fallow fields, along roads; Sakh: IS ?; is reported for Western Sakhalin Mountainous Area and Southern Sakhalin Plain (Barkalov \& Taran 2004); Khab: IS 4; forms continuous cover on dry slopes along railway tracks; Amur: IS 3; Yak: IS ?; included in the list of species found before 1926 (Komarov 1926, Nikolin 2014, 2016); meadow and steppe species acting as a ruderal and segetal weed; occurs rarely, in southern districts; Mag: IS ?; a colonophyte, colonizes fallow fields, lawns; individual plants (Lysenko 2012); Kam: IS 4; occurs sporadically in man-made habitats (Chernyagina \& Devyatova 2018).

\section{Brassica juncea (L.) Czern.}

Distribution in Asian Russia: Al, Ch Sh, GA, Ha, Ir_An, $\mathrm{Ke}, \mathrm{Kr} \_\mathrm{Pu}, \mathrm{Kr}$-TN, Kr_Ve, Ku, NB, NK, No, Ok, Om, SB, SK, SS, Tm_Tb, To, Ty, Us, Yk_Al.

Prim: IS 2-3; prevalent in fields, on waste grounds, along roads, on railway embankments; penetrates river pebble deposits (Prokopenko 2011); Sakh: IS ?; reported for almost all districts of Sakhalin Island (Barkalov \& Taran 2004); Khab: IS ?; a crop weed, individual plants occur in ruderal habitats, is not included in the list of invasive species; Yak: a rare weed cited for central Yakutia by Komarov (1926) according to old collections. A potentially dangerous segetal species, which has not yet become prevalent in Yakutia; Mag: an ephemerophyte; roadside areas, kitchen gardens, weeds in the crops of annual grasses (Lysenko 2012).

\section{Bunias orientalis $\mathrm{L}$.}

Distribution in Asian Russia: Al, GA, Ha, Ir_An, Ka, Ke, $\mathrm{Kr} \_\mathrm{Pu}, \mathrm{Kr} \_\mathrm{Ve}, \mathrm{Ku}, \mathrm{No}, \mathrm{NS}, \mathrm{SB}, \mathrm{SS}, \mathrm{Tm} \_\mathrm{Tb}, \mathrm{To}$, Us, Yk_Al,

Prim: IS 2-3; in populated areas along roads, along field edges, in ruderal habitats, on the seashore, in the vicinity of the city of Nakhodka penetrates disturbed forest clearings and margins; Sakh: IS ?; reported from some districts of central and southern Sakhalin (Barkalov \& Taran 2004); Khab: several times was found in the vicinity of the city of Khabarovsk, not included in the list of invasive species; Yak: first mentioned by Galaktionova (Tolmachev 1974) as a weed near the city of Aldan; the plant was not collected later; Kam: IS 4; occurs only in Yelizovo and Ust-Bolsheretsk Districts, sporadically in anthropogenic habitats (Chernyagina \& Devyatova 2018).

\section{Cakile edentula (Bigelow) Hook.}

Distribution in Asian Russia: SK, SS, Us.

Prim: IS ?; in all bays of Khasansky District from Sivuchya Bay in the south up to the De-Friz Peninsula near Vladivostok; in 2013, it was found on the sandy shores in Narva Bay, where it occurs sporadically, as individual plants or as thinned groups of several individuals only in open plant communities of the supralittoral zone (Kozhevnikova \& Kozhevnikov 2016); invades supralittoral communities, quickly reproduces and pushes out native species (Fukuda et al. 2015); Sakh: IS ?; south of Sakhalin Island (Smirnov 2009), in Kuril Islands (Kunashir and Iturup) is common on sandy seashore, rare on Shikotan Island (Fukuda et al. 2014).

\section{Capsella bursa-pastoris (L.) Medik.}

Distribution in Asian Russia: Al, Am, Bu, Ch_Ka, Ch Sh, Co, Da, E_Al, GA, Ha, Ir_An, Ir_Pr, Ka, Ke, Kl, Kr, $\mathrm{Kr} \_\mathrm{Pu}, \mathrm{Kr} \_\mathrm{Ta}, \mathrm{Kr}$-TN, Kr $\mathrm{Ke}_{\mathrm{V}} \mathrm{Ku}, \mathrm{LZ}, \mathrm{NB}, \mathrm{Nj}, \mathrm{NK}, \mathrm{No}$, NS, Ok, Om, SB, SK, SS, Tm_HM, Tm_Tb, Tm_Ya, To, Ty, Us, UZ, Yk_Al, Yk_Ar, Yk_Ko, Yk_Ol, Yk_Vi, Yk_Ya.

Prim: IS 2-3; in populated areas along streets, on waste grounds, in kitchen gardens, fields, on grazing grounds, 
along roads, in some places invades river pebble deposits; Sakh: IS 3; reported from almost all districts of Sakhalin Island (Barkalov \& Taran 2004), a common synanthropic species in Kuril Islands (Fukuda et al. 2014); Khab: IS ?; the species introduced at the initial stages of the region's exploration and colonized all suitable ecological niches, no invasion trends to seminatural and natural communities are observed; Amur: IS 3; Yak: IS 2; included in the list of species found before 1926 (Komarov 1926; very aggressive weed species (Nikolin 2014, 2016); Mag: IS 3; epecophyte, colonizes waste grounds, roadside areas, trampled artificial meadows, kitchen gardens, potato fields; rare in all districts (Lysenko 2012); Kam: IS 3; occurs in all districts, epecophyte (Chernyagina \& Devyatova 2018).

\section{Descurainia sophia (L.) Webb ex Prantl.}

Distribution in Asian Russia: Al, Am, AP, Ch_Ka, Ch_ Sh, E_Al, GA, Ha, Ir_An, Ir_Pr, Ka, Ke, Kl, Kr, Kr_Pu, $\mathrm{Kr} \_\mathrm{TN}, \mathrm{Kr} \_\mathrm{Ve}, \mathrm{Ku}, \mathrm{LZ}, \mathrm{NB}, \mathrm{No}, \mathrm{Ok}, \mathrm{Om}, \mathrm{SB}, \mathrm{SS}, \bar{T}_{-}$ HM, Tm_Tb, To, Ty, Us, Yk_Al, Yk_Ko, Yk_Ol, Yk_Vi, Yk_Ya.

Prim: does not invade seminatural and natural communities. Sakh: IS ?; reported from the southwestern area and Southern Sakhalin Plain (Barkalov \& Taran 2004); Khab: introduced at the initial stages of the region's exploration and colonized all suitable ecological niches, no invasion trends to seminatural and natural communities are observed; Amur: IS 4; epecophyte, first collections were registered in 1859 by Maximowicz in the vicinity of Chinese village Dzikirai; nowadays occurs rarely in the Region, usually associated with disturbed and ruderal habitats (Aistova 2009); Yak: IS - included in the list of species found before 1926 (Nikolin 2014). A prevalent highly aggressive segetal and ruderal species, status 3. Mag: IS - an agriophyte, colonizes abandoned kitchen gardens, landfills, waste grounds, gold mining tailings, pebble deposits. Rarely in Okh., Okh.-Kol., Kol. (Lysenko 2012), status 3. Kam: IS sporadically occurs next to dwellings, along roads, in fields and kitchen gardens, status 4 (Chernyagina \& Devyatova 2018).

\section{Hesperis matronalis $\mathrm{L}$.}

Distribution in Asian Russia: Bu, Ka, SK, Us.

Prim: IS 2; recently has escaped from culture massively and occurs near populated areas and in allotment gardens, on waste grounds, dumpsites, in forest margins; Khab: IS 4; reported since the end of the 20th century as a wildling, individual plants occur in floodplain complexes, in forest margins, shrub communities; Jew: IS 4; Kam: IS ?; colonophyte in some districts (Chernyagina \& Devyatova 2018).

\section{Lepidium densiflorum Schrad.}

Distribution in Asian Russia: Al, Am, Bu, Ch_Ka, Ch_ Sh, Da, GA, Ha, Ir_An, Ir_Pr, Ka, Kl, Kr_Ve, LZ, NB, No, NS, Ok, Om, SB, SS, Ty, Us, UZ, Yk_Al, Yk_Vi, Yk_Ya.

Prim: IS 2; abundant species in populated areas, is also common in roadside areas, on waste grounds, in trampled areas, on sands and pebble along the seashore and river valleys; Sakh: IS ?; reported for districts in all parts of Sakhalin Island (Barkalov \& Taran 2004); Khab: IS ?; the species introduced at the initial stages of the region's exploration and colonized all suitable ecological niches, no invasion trends are observed; Bur, Zab: status requires clarification (Ebel et al. 2016); Yak: IS ?; occurs in central, southern, northwestern and arctic regions but less frequently than a closely related species $-\boldsymbol{L}$. apetalum Willd; both species are highly aggressive ruderal and pasture weeds (Nikolin 2016); Mag: IS ?; epecophyte; roadsides, waste grounds, trampled artificial meadows (Lysenko 2012); Kam: IS 4; rare, reported only from the populated areas of Yelizovo District (Chernyagina \& Devyatova 2018).

\section{Thlaspi arvense $\mathrm{L}$.}

Distribution in Asian Russia: Al, Ch_Sh, GA, Ha, Ir_An, Ir_Pr, Ka, Ke, Kl, Kr, Kr_Pu, Kr_TN, Kr_Ve, Ku, LZ, NB, No, Ok, Om, SB, SS, Tm_Tb, Tm_Ya, To, Ty, Us, Yk_Al, $\mathrm{Yk}_{-} \mathrm{Vi}$.

Prim: IS 2; prevalent as a weed, grows in roadside areas, on waste grounds, in fields, along railway tracks, in some places reported from pebble and sand deposits along rivers and seashore and from floodplain forests; Sakh: IS ?; reported from some districts of central and southern Sakhalin (Barkalov \& Taran 2004); Khab: IS ?; the species introduced at the initial stages of the region's exploration and colonized all suitable ecological niches, no invasion trends to seminatural and natural communities are observed; Amur: IS 3; an epecophyte, a prevalent weed (Aistova 2009); Yak: IS 3; included in the list of species found before 1926 (Komarov 1926, Nikolin 2014); prevalent and highly aggressive segetal and ruderal species in central and southern districts (Nikolin 2016); Mag: IS 3; epecophyte, colonizes roadside areas, kitchen gardens, waste grounds, artificial meadows, gold mining tailings (Lysenko 2012); Kam: IS 4; occurs mostly in disturbed areas (Chernyagina \& Devyatova 2018); Chuk: IS ?; collected near the Lorino's hot springs (Khokhryakov 1985) and in the middle reaches of the Bol. Anyui River (Baimka settlement); weed plant (Jurtsev et al. 2010).

\section{Turritis glabra L.}

Distribution in Asian Russia: Al, Ch_Sh, GA, Ha, Ir_An, Ir_Pr, Ke, Kr_Ve, Ku, NB, No, NS, Om, SB, SK, SS, Tm_ HM, Tm_Tb, To, Us.

Prim: IS 2-3; on railway embankments, along roads, reported from stony slopes and mountain tops, in shrub communities, on pebble along rivers; Sakh: IS ?; reported from many districts of central and southern Sakhalin (Barkalov \& Taran 2004); Khab: occurs sporadically on railway embankments, along roads, on stony slopes, less frequently on pebble deposits along rivers; is not included in the list of invasive species.

\section{Velarum officinale (L.) Reichenb.} (= Sisymbrium officinale (L.) Scop.).

Distribution in Asian Russia: Al, Bu, GA, Ha, Ir_An, Ke, Kr_Ve, LZ, No, Om, SK, SS, Tm_Tb, To, Us, Yk_Vi.

Prim: IS 2-3; abundant species in populated areas, in roadsides, trampled areas, penetrates into the river banks; Sakh: IS ?; reported for the southern districts of Sakhalin Island (Barkalov \& Taran 2004); Khab: the species introduced at the initial stages of the region's exploration and colonized all suitable ecological niches, no invasion trends are observed; Bur: IS 4 (Ebel et al. 2016). Yak: first mentioned by Karavaev (1958) as a very rare weed reported from the ruderal habitats in the vicinity of the city of Yakutsk; potentially dangerous weed, but not very active (Nikolin 2016).

\section{CAMPANULACEAE}

\section{Campanula rapunculoides $\mathrm{L}$.}

Distribution in Asian Russia: GA, Ka, SB, SS, To, Us.

Prim: IS ?; massively escapes from culture and penetrates into various phytocenoses. Sakh: IS 3; reported from the southern districts of Sakhalin Island (Barkalov \& Taran 2004); Khab: cultivated as an ornamental plant, occasionally goes in wilderness, does not invade seminatural and 
natural communities, not included in the list of invasive species; Kam: IS 4; occurs in Bystrinsky, Yelizovo and Milkovo Disricts (Chernyagina \& Devyatova 2018).

\section{CANNABACEAE}

\section{Cannabis sativa $\mathrm{L}$.}

Distribution in Asian Russia: Al, Am, Bu, Ch_Ka, Ch $\mathrm{Sh}, \mathrm{GA}, \mathrm{Ha}$, Ir_An, Ir_Pr, Ka, Ke, Kr_Pu, Kr_Ta, Kr_TN, Kr_Ve, Ku, NB, NK, No, Om, SB, SS, Tm_HM, Tm_Tb, To, Ty, Us, Yk_Al, Yk_Ko, Yk_Vi, Yk_Ya.

Prim: IS 2; occurs rarely on dumpsites and along roads; reported from floodplain forests and Alnus japonica forests; Sakh: IS 3-4; mentioned for the southwestern area of Sakhalin Island (Barkalov \& Taran 2004); the species is very rare, exclusively cultivated; naturalization has not been noted; Khab: occurs as individual plants in ruderal habitats, occasionally in disturbed meadow and shrub communities; not included in the list of invasive species; Yak: IS 2-3; first mentioned by Tarabukin (1932), "Occurs on sandy soils, along rivers, on dumpsites, sandy fallow fields, along roads, on sandy slopes and in forest margins"; later, Karavaev (1958) mentioned it as a rare weed for central (including Vilyui areas) and southern districts; nowadays, the species is not rare and in some places forms dence communities on waste grounds and in fallow fields; government agencies combat the spread of the species as a source of raw materials for illegal drug manufacture; dangerous and a highly aggressive segetal and ruderal weed; Mag: ephemerophyte, reported on landfills, very rarely in the vicinity of Magadan (Lysenko 2012); Kam: cited according to old collections from central Kamchatka, but recently it has not been reported.

\section{Humulus lupulus L.}

Distribution in Asian Russia: Al, Ch_Ka, GA, Ha, Ir An, Ir_Pr, Ke, Kr_Ve, Ku, LZ, No, Om, SB, SS, Tm_HM, Tm_Tb, To, Us.

Prim: IS ?; abundant species, occurs frequently; according to Vorob'ev (1954) "Common hop penetrated riverside forests and shrub communities near the village of Glazovka of Shmakovsky [Lesozavodsky] District and willow stands near the village of Maryanovka of Kirovsky District"; Sakh: IS 4; reported for some districts of central and southern Sakhalin (Barkalov \& Taran 2004); Khab: IS 1; penetrates into rills, road ditches, floodplains of small rivers (Antonova 2012); Jew: IS 1; reported both from populated areas and phytocenoses disturbed by human activity, spreads massively (Rubtsova 2017); Amur: IS 3; epecophyte, occurs mostly in culture, less frequently in ruderal habitats (Aistova 2009); Kam: IS ?; colonohyte in Bystrinsky, Milkovo and Yelizovo Disricts (Chernyagina \& Devyatova 2018).

\section{CARYOPHYLLACEAE}

\section{Cerastium holosteoides Fr.}

Distribution in Asian Russia: Al, Am, Bu, Ch_Sh, Co, Da, E_Al, GA, Ha, Ir_An, Ir_Pr, Ka, Ke, Kr_TN, Kr_Ve, $\mathrm{Ku}, \mathrm{LZ}, \mathrm{NB}, \mathrm{NK}, \mathrm{No}, \mathrm{NS}, \mathrm{Ok}, \mathrm{Om}, \mathrm{SB}, \mathrm{SK}, \overline{\mathrm{SS}}, \mathrm{Tm} \_\overline{\mathrm{H} M}$, Tm_Tb, To, Ty, Us, UZ.

Prim: IS 2; prevalent species, occurs in roadside areas, fields, on sand and pebble deposits along rivers and on the seashore, occasionally reported on dry meadows, in forest margins, floodplain forests, and moist Alnus japonica forests; Sakh: IS 2; reported for districts in all parts of Sakhalin Island (Barkalov \& Taran 2004), common on Iturup Island (Fukuda et al. 2014); Khab: does not invade seminatural and natural communities (Antonova 2012), not included in the list of invasive species; Yak: IS ?; first mentioned by Komarov (1926) for central districts; later was mentioned by
Karavaev (1958) as a rare weed; potentially dangerous weed, but not very active (Nikolin 2016); Mag: IS 3; epecophyte, colonizes waste grounds, roadside areas, artificial meadows, fallow fields (Lysenko 2012); Kam: IS 3; occurs in all districts, except Penzhinsky District; a common species in disturbed habitats (Chernyagina \& Devyatova 2018).

\section{Saponaria officinalis $\mathrm{L}$.}

\section{Distribution in Asian Russia: Al, SK, SS, Us.}

Prim: IS 2-3; common in roadsides, on dumpsites, especially in Shkotovsky District; according to Vorob'ev (1954), it occurs on pebble deposits and in open associations of the Sukhodol (Kangauz) River valley; Sakh: IS ? mentioned for Tymsky District of Sakhalin Island (Barkalov \& Taran 2004), reported from Iturup Island as an escapee from culture (Fukuda et al. 2014); Khab: cultivated, sometimes goes in wilderness and can grow during a long time on railway embankments and in roadside areas; not included in the list of invasive species; Bur: IS 4; potentially invasive species capable of reproduction, occasionally invading seminatural communities (Ebel et al. 2016).

\section{Scleranthus annuus $\mathrm{L}$.}

Distribution in Asian Russia: $\mathrm{Bu}, \mathrm{Ha}, \mathrm{Kr} \_\mathrm{Ve}, \mathrm{Ku}, \mathrm{LZ}$, No, NS, SS, Us.

Prim: IS 2; frequently occurs in northern districts, found on sands and rocks of the seashore in Dalnegorsk District (Vorob'ev 1964); common along roads, reported from pebble and sand deposits along rivers; Sakh: IS ?; reported from some districts of central and southern Sakhalin (Barkalov \& Taran 2004); Khab: occurs in small groups or bands on crushed stony and loamy roadside areas, less frequently along pebble and muddy river banks, is not included in the list of invasive species.

\section{Spergula arvensis $\mathrm{L}$.}

Distribution in Asian Russia: Al, Am, Bu, Da, GA, Ir_Pr, $\mathrm{Ka}, \mathrm{Ke}, \mathrm{Kr} \_\mathrm{Pu}, \mathrm{Kr} \_\mathrm{Ve}, \mathrm{Ku}, \mathrm{LZ}, \mathrm{Nj}, \mathrm{NK}, \mathrm{No}, \mathrm{NS}, \mathrm{Ok}, \bar{O}_{\mathrm{m}}$, SK, SS, Tm_HM, Tm_Tb, Tm_Ya, To, Us, UZ, Yk_Vi.

Prim: IS 3; reported from fields, kitchen gardens, along roads, railway embankments; Sakh: IS ?; reported from districts in all parts of Sakhalin Island (Barkalov \& Taran 2004), in Kuril Islands it occurs often in Kunashir and Iturup Islands) (Fukuda et al. 2014); Khab: weed and a ruderal species, in the east of the Territory often occurs far from populated areas in the roadside areas of logging roads, not included in the list of invasive species; Amur: IS 3; epecophyte, a weed, may be used as fodder (Aistova 2009); Yak: first mentioned by Karavaev (1958) as a rare weed, occurring in crops and kitchen gardens, in central and southern districts; nowadays, it is still rare, but spreads with the crop plant seeds; potentially dangerous weed but not very active (Nikolin 2016); Mag: IS 2; agriophyte, colonizes potato fields, kitchen gardens, "young" fallow fields, waste grounds, pebble and sand and mud deposits along river banks, a weed in annual grass crops (Lysenko 2012); Kam: IS 4; common in disturbed habitats, from which it quickly disappears (Chernyagina \& Devyatova 2018).

\section{CONVOLVULACEAE}

\section{Convolvulus arvensis $\mathrm{L}$.}

Distribution in Asian Russia: Al, Bu, Ch_Sh, Da, GA, $\mathrm{Ha}, \mathrm{Ir} \_\mathrm{An}, \mathrm{Ir} \_\mathrm{Pr}, \mathrm{Ke}, \mathrm{Kl}, \mathrm{Kr} \_\mathrm{TN}, \mathrm{Kr} \_\mathrm{Ve}, \mathrm{Ku}, \mathrm{LZ}, \mathrm{NK}, \mathrm{No}$, NS, Ok, Om, SB, SK, SS, Tm_Tb, To, Ty, Us, Yk_Vi.

Prim: IS 3; on railway embankments, in fields, kitchen gardens, along roads; Sakh: IS ?; reported from some districts of central and southern Sakhalin (Barkalov \& Taran 2004), 
reported from the city of Kurilsk on Iturup Island (Fukuda et al. 2014); Khab: IS 3; recently considerably reduced frequency (Antonova 2012); Jew: IS 3; Amur: IS ?; epecophyte, occurs on dumpsites, railway embankments, along roads and in grain crops; Yak: IS ?; first reported by Karavaev (1958); occurs rarely, on steppe crushed stony slopes of the Lena River upward from its right tributary Buotum River, and in the catchment basin of the Chona River (tributary of the Vilyui River); reported also from fallow fields (Cherosov 2012); potentially dangerous cosmopolitan species acting in some territories as an aggressive species (Nikolin 2016), included in the list of species found after 1926 (Nikolin 2014); Mag: IS ?; ephemerophyte and colonophyte, colonizes lawns, landfills, cabbage fields (Lysenko 2012); Kam: IS 3-4; occurs in populated areas of Milkovo and Bystrinsky Districts, and also in the city of Petropavlovsk-Kamchatsky; in the town of Anavgai of Bystrinsky District enters a meadow next to the warm stream (Chernyagina \& Devyatova 2018).

\section{CUCURBITACEAE}

\section{Echinocystis lobata (Michx.) Torr. et Gray.}

Distribution in Asian Russia: Bu, Ch_Sh, GA, Ir_An, $\mathrm{Ka}, \mathrm{Kr} \_\mathrm{Ve}, \mathrm{Ku}, \mathrm{LZ}, \mathrm{No}, \mathrm{Om}, \mathrm{SS}, \mathrm{Tm} \_\mathrm{Tb}, \mathrm{Ty}, \mathrm{Us}, \mathrm{Yk}$ _Vi.

Prim: IS 2; occurs in populated areas along roads and dumpsites; near the city Spassk-Dalny and along the Partizanskaya River reported from under the canopy and from the margins of floodplain forests; Sakh: IS 4; mentioned for Southern Sakhalin Plain (Barkalov \& Taran 2004); Khab: IS 1; penetrates into the rills, road ditches, floodplains of small rivers (Antonova 2012); Jew: IS 1; mostly active in natural phytocenoses; Amur: IS 2; epecophyte, occurs on dumpsites and waste grounds in populated areas, along roads, less frequently in floodplain shrub communities (Aistova 2009); Bur: IS 4; introduced in culture since 1960s and was initially used for wall ornamentation, later spreaded to the catchment area of the Selenga River in steppe and forest-steppe areas; Zab: IS 4; in 1988 was collected in Ononsky District of Chita Region (Vinogradova 2006, Ebel et al. 2016); Yak: first mentioned by Galaktionova (Tolmachev 1974) as an alien plant in the kitchen garden in the village of Krestovaya (at present the village of Krestovsky Lesouchastok) in the head of the Lena River; herbarium specimens collected in 2002 from the vicinity of city Yakutsk are available in SASY; occurs rarely, stays in one place for a short time, not very active (Nikolin 2016); Kam: known in culture in the village of Milkovo.

\section{CUSCUTACEAE}

\section{Cuscuta campestris Yunck.}

Distribution in Asian Russia: Bu, Ch_Sh, No, Us.

Prim: does not invade seminatural and natural communities; Khab: occurs rarely in synanthropic communities. Amur: IS 1; ephemerophyte, first collected in 1993 in the village of Arkhara (VLA) and is reported from the southern part of the Region; later found in 2002 in the town Fevralsk of Selemdzhinsky District and in 2008 in Blagoveshchensk in the roadside (Aistova 2009); Bur: not reported (Ebel et al. 2016); Zab: first found in 1963 on a rocky slope near the village Abagatui on the Argun River; herbarium specimens "...along the left bank of the Tsagan-Gola River" (1927), "Aginskaya steppe, village of Kuzhertai, near the Onon River" (1909), "Chitinsky Okrug, Borzinsky District, northern margin of Zun-Torei Lake - stony hills" (1931); nowadays, due to the quarantine, only few locations are known; this species does not penetrate into the natural communities, associates with ruderal habitats and agrocenoses (Ebel et al. 2016).

\section{Cuscuta europaea L.}

Distribution in Asian Russia: Al, Am, Ch_Ka, Ch_Sh, $\mathrm{Da}, \mathrm{E} \_\mathrm{Al}, \mathrm{GA}, \mathrm{Ha}$, Ir_An, Ir_Pr, Ke, Kr_TN, Kr_Ve, Ku, $\mathrm{LZ}, \mathrm{NB}, \mathrm{No}, \mathrm{Om}, \mathrm{SB}, \mathrm{SS}, \mathrm{Tm} \_\mathrm{Tb}, \mathrm{To}, \mathrm{Ty}, \mathrm{Us}, \mathrm{Yk} \_\mathrm{Al}, \mathrm{Yk}$ Vi.

Prim: IS 2; recently has become one of the abundant species along roadside areas, on meadows, penetrates natural phytocenoses; Sakh: IS ?; mentioned for the Lamanon coastal area of Sakhalin Island (Barkalov \& Taran 2004); Khab: IS 4; in the beginning of 1970 s reported as a rare species in Ulchsky and Nikolaevsky Districts (Shaga 1974). Parasitizes on Vicia spp., Trifolium spp., Medicago spp., Cannabis sativa, but occurs rarely; Bur, Zab: IS 4 (Ebel et al. 2016); Yak: IS ?; native species first reported by Komarov (1926); occurs quite frequently, common in central and southern Yakutia (mostly along the Lena River), in shrub communities, on meadows, pebble deposits, sometimes acts as a segetal weed.

\section{DIPSACACEAE}

\section{Knautia arvensis $\mathrm{L}$.}

Distribution in Asian Russia: Al, Am, Ha, Ir_An, Ka, Ke, Kr_Ve, Ku, No, NS, Om, SB, SS, Tm_Tb, To, Us, Yk_Al, Yk_Ko.

Prim: IS 3; on dumpsites along roads and on railway embankments in Vladivostok and the village Anisimovka (Nechaeva 1998); Sakh: IS ?; reported from the Western Sakhalin Mountainous Area and Tymsky District of Sakhalin Island (Barkalov \& Taran 2004); Khab: occurs rarely, not included in the list of invasive species; Yak: first mentioned by Galaktionova (Tolmachev 1974) as an alien plant in the catchment areas of Aldan (city of Aldan) and Kolyma Rivers; rare weed, not very active; Kam: IS 2; occurs in Yelizovo District, mainly along highways beyond populated areas, reported on meadows and in roadside willow forests; agriophyte (Chernyagina \& Devyatova 2018).

\section{ELAEAGNACEAE}

\section{Hippophae rhamnoides $\mathrm{L}$.}

Distribution in Asian Russia: Al, Bu, GA, Ir_An, LZ, $\mathrm{Ka}, \mathrm{SB}, \mathrm{Ty}$, Us.

Prim: IS 2; escapes from culture, forms spontaneous plantations, near the city of Nakhodka forms small communities and groups on the seashore terrace in the estuary of the Partizanskaya River, fruiting abundantly; Khab: IS 1; actively spreads along roadside areas of automobile roads and railroads and along the banks of the Amur River, in forest margins forms part of shrub and forest communities (Antonova 2012); Jew: IS 2; Amur: IS 1; Kam: IS 4; seed propagation on dumpsites in Milkovo and Yelizovo Districts is observed (Chernyagina \& Devyatova 2018).

\section{EUPHORBIACEAE}

\section{Euphorbia virgata Waldst. et Kit. (=Euphorbia waldsteinii (Soják) Czerep.)}

Distribution in Asian Russia: Al, Bu, GA, Ha, Ir_An, Ir_Pr, Ka, Ke, Kr_Ve, Ku, No, NS, Om, SB, SS, Tm_Tb, Ty, Us.

Prim: IS 3; roadside areas, railway embankments, fields; Sakh: IS ?; reported from some districts of central and southern Sakhalin (Barkalov \& Taran 2004); Khab: all known localities are associated with the railway tracks; during the last 20 years the distribution area has changed very little; not included in the list of invasive species; Mag: IS ?; deposits, meadows, wastelands, roadsides (Lysenko 2012); Kam: IS ?; known in culture, sometimes occurs away from flowerbeds. 


\section{FABACEAE}

Amorpha fruticosa $\mathrm{L}$.

Distribution in Asian Russia: Us.

Prim: IS 3; cultivated in many districts; escapes from culture, goes in wilderness, is reported along roads; in 2014 a large uneven-aged population was found in south-western Primorye (near the town of Kraskino) (10 000 sq. m) dominating the landscape (wet and swamp grasslands with shrubs); the plants are flowering and fruiting abundantly; the presence of young plants in the population demonstrates successful self-reproduction of the species and proves its status as a colonophyte (Kozhevnikova \& Kozhevnikov 2016); Khab: known only in culture, shoots freeze, that is why it is not frequently used in gardening; not included in the list of invasive species.

\section{Lotus corniculatus $\mathrm{L}$.}

Distribution in Asian Russia: Us.

Prim: IS 2-3; pastures, grazing grounds, dry meadows; Khab: IS 4; first found near Komsomolsk-na-Amure (Schlotgauer \& Schroeter 1969); rare; over the past three years has spread massively along the seashore near village Vanino.

\section{Lupinus polyphyllus Lindl.}

Distribution in Asian Russia: Bu, Ka, NS, Ok, SS, Us.

Prim: does not behave as a weed; Sakh: IS 1-2; reported for the districts of southern Sakhalin (mistakenly as L. nootkatensis Donn, Barkalov \& Taran 2004), encountered in the city of Kurilsk on Iturup Island (Fukuda et al. 2014); For almost a century, it dominates meadows, slowly expanding the areas of its monodominant distribution; now it is actively used to create herb cover for skiing infrastructure in southern Sakhalin; Khab: only as a cultivated plant; Bur: IS 3; reported for the first time near the town of Tankhoi, near the office of Baikal Nature Reserve in 2009 (Ebel et al. 2016); Mag: only as a cultivated plant; Kam: IS 1; common only in Yelizovo District - in Petropavlovsk-Kamchatsky along the basements of buildings, on untended lawns, dumpsites, in abandoned small holdings and kitchen gardens, on seashore slopes; encountered in roadside grass or willow stands in the town of Termalny and near it, in reedgrass meadows along the Khalaktyrsky road; is prevalent in the city of Yelizovo and nearby towns, occurs in the city of Vilyuchinsk (Chernyagina \& Devyatova 2018, Abramova et al. 2017).

\section{Medicago lupulina L.}

Distribution in Asian Russia: Al, Ch, Ch_Sh, Da, GA, $\mathrm{Ha}, \mathrm{Ir} \_\mathrm{An}, \mathrm{Ir} \_\mathrm{Pr}, \mathrm{Ke}, \mathrm{Kr} \_\mathrm{Pu}, \mathrm{Kr} \_\mathrm{Ve}, \mathrm{Ku}, \mathrm{LZ}, \mathrm{NB}, \mathrm{No}$, Om, SB, Tm_Tb, To, Ty, Us, Yk_Ar.

Prim: IS 2-3; prevalent, grows in roadside areas, on railway embankments, waste grounds, penetrates river pebble deposits; Khab: common ruderal plant colonizing biotopes with sufficient watering; not included in the list of invasive species; Yak: once reported from the town Tiksi (Polozhii \& Malyshev 1994), but the species has not remained there until now; Chuk: Chukotka Upland (town Komsomolsky); heavily manured place in small holdings.

\section{Melilotus albus Medik.}

Distribution in Asian Russia: Al, Bu, Ch_Sh, Da, GA, $\mathrm{Ha}$, Ir_An, Ir_Pr, Ka, Ke, Kr_TN, Kr_Ve, Ku, LZ, NB, No, Ok, Om, SB, SS, Tm_Tb, To, Ty, Us, Yk_Vi.

Prim: IS 2-3; along the roads, on waste grounds, in fallow fields, on railroad tracks, a weed in crops; in 2018, groups of plants were observed in the city of Dalnegorsk, along the river; before that on the slopes along roads, along railway tracks; Sakh: IS 2-3; reported for some districts of central and southern Sakhalin (Barkalov \& Taran 2004); Khab: IS 3; continues to actively colonize roadsides, areas along railway tracks; Amur: IS 3; - an epecophyte, appeared when the Russians came to the Region; nowadays occurs in ruderal habitats, sometimes enters grain and soybean crops but not active (Aistova 2009); Yak: IS 2-3; found before 1926 (Komarov 1926); prevalent and sometimes massive in central and southern districts, colonizes waste grounds, yards, roadside areas, field boundaries and fallow fields; highly aggressive segetal and ruderal weed (Nikolin 2016); Mag: IS ?; colonophyte; colonizes waste grounds, artificial meadows, lawns, gold mining tailings (Lysenko 2012). Kam: IS 3; common in Milkovo and Yelizovo Districts on waste grounds, lawns, in roadside areas (Chernyagina \& Devyatova 2018).

\section{Robinia pseudoacacia L.}

\section{Distribution in Asian Russia: SK, SS, Us.}

Prim: IS 3; commonly used in urban landscaping and escapes from culture, although the species is not as aggressive as Acer negundo; in some districts (for example, near the city Arsenyev) actively propagates by seed; vegetative propagation along roads, on waste grounds, in disturbed shrub communities was reported; Sakh: IS 74; reported from southern Sakhalin (Barkalov \& Taran 2004); Khab: very rarely cultivated in southern districts, hardly survives.

\section{Trifolium arvense $\mathrm{L}$.}

Distribution in Asian Russia: Al, Ha, $\mathrm{Kr}_{-} \mathrm{Ve}, \mathrm{Ku}, \mathrm{LZ}$, No, Ok, Om, SS, Tm_Tb, To, Us.

Prim: IS 2; on seashore and river pebble deposits and dry slopes (Nechaeva 1998); nowaddays, grows along roads, on railway embankments, waste grounds, in some places penetrates into the meadows and seashore sands; Sakh: IS ?; reported from some districts of Southern Sakhalin (Barkalov \& Taran 2004); Khab: IS 4; common plant on dry slopes, waste grounds, railway embankments, sea and river pebble deposits near populated areas, in the southern part of the coast; Mag: very rare in Magadan, on the lawns (Khoreva 2018).

\section{Trifolium campestre Schreb.}

Distribution in Asian Russia: Bu, Ku, LZ, Ok, SK, To, Us.

Prim: IS 2; common species, forms communities along roads, in some places penetrates into the meadows; Sakh: IS 3; encountered in the Kurilsk on Iturup Island (Fukuda et al. 2014); disturbed habitats of the South Sakhalin Plain, including coastal communities; Khab: colonizes dry habitats with a thin vegetation cover, forms part of ruderalized meadows, is included in the list of invasive species; Mag: IS ?; colonophyte(Lysenko 2012).

\section{Trifolium hybridum $\mathrm{L}$.}

Distribution in Asian Russia: Al, Ch_Sh, GA, Ir_An, Ir_ $\mathrm{Pr}, \mathrm{Ka}, \mathrm{Ke}, \mathrm{Kr} \_\mathrm{Pu}, \mathrm{Kr} \_\mathrm{Ve}, \mathrm{Ku}, \mathrm{LZ}, \mathrm{NK}$, No, NS, Ok, Om, SB, SK, SS, Tm_HM, Tm_Tb, Tm_Ya, To, Ty, Us, Yk_Al.

Prim: IS 2-3; Vorob'ev (1954) reported its penetration in natural phytocenoses; reported for crops and as a wildling on meadows, grazing grounds and along roads (Tolmachev 1966); nowadays, very common, predominantly in roadsides, in some places penetrates into dry meadows and floodplain forests; Sakh: IS 2-3; reported from districts in all parts of Sakhalin Island (Barkalov \& Taran 2004), encountered in the city of Kurilsk on Iturup Island (Fukuda et al. 2014); 
Khab: not included in the list of invasive species; Amur: IS 4; ephemerophyte, a rare plant for the region; known from herbarium collections from the beginning of the 20th century from Ulanga station; occurs along roadsides in Blagoveshchensk and Bureisky Districts (Aistova 2009); Bur, Zab: IS 4 (Ebel et al. 2016); Yak: Komarov (1926) mentioned this species for Yakutsk (central disticts), later it was cited only for Aldan floristic district (Karavaev 1958, Cherosov 2012); occurs rarely, spreads along roads; Mag: IS 3; epecophyte; colonizes roadsides, lawns, artificial meadows, fallow fields (Lysenko 2012); Kam: IS 3; occurs in disturbed habitats in Yelizovo, Milkovo, Tigil and Karaga Districts (Chernyagina \& Devyatova 2018).

\section{Trifolium pratense L.}

Distribution in Asian Russia: Al, Am, AP, Bu, Ch_Sh, $\mathrm{Da}, \mathrm{GA}, \mathrm{Ha}$, Ir_An, Ir_Pr, Ka, Ke, Kr_Pu, Kr_TN, Kr_Ve, $\mathrm{Ku}, \mathrm{LZ}, \mathrm{NB}, \overline{\mathrm{NK}}$, No, NS, Ok, Om, SB, SK, $\overline{\mathrm{S}}$, Tm_HM, Tm_Tb, Tm_Ya, To, Ty, Us, Yk_Al, Yk_Vi.

Prim: IS 2; along roads, on grazing grounds, in the fields, in some places penetrates into the meadows; Sakh: IS 2; reported for all districts of Sakhalin Island, in meadows (Barkalov \& Taran 2004), a common species in Kuril Islands (Fukuda et al. 2014); Khab: naturalized long ago, grows on ruderalized meadows, on farmlands, where it was sowed; no active spread and naturalization in natural disturbed and seminatural communities indicated; not included in the list of invasive species; Amur: IS 2; epecophyte, escape from culture and spreading along roadside areas, fields, river banks is possible; sustainable in disturbed cenoses (Aistova 2009); Yak: IS ?; first reported by Tarabukin (1932): "occurs on floodplain and dry meadows, in shrub communities, on field boundaries, in fallow fields and occasionally in crops"; common in central and southern districts, does not occur frequently, a valuable fodder plant, does not demotstrate threat as a weed (Nikolin 2016); Mag: IS 3; agriophyte, colonizes roadside areas, lawns, artificial meadows, fallow fields, waste grounds, gold mining tailings (Lysenko 2012); Kam: IS 3; occurs everywhere in disturbed areas (Chernyagina \& Devyatova 2018); Chuk: IS ?; Anadyr River catchment area (city Anadyr, town Markovo, Beringovskiy village); weed species near houses, in roadside areas.

\section{Trifolium repens $\mathrm{L}$.}

Distribution in Asian Russia: Al, Am, Bu, Ch, Ch_Sh, Co, Da, E_Al, GA, Ha, Ir_An, Ir_Pr, Ka, Ke, Kr, Kr_Pu, $\mathrm{Kr}$-TN, Kr_Ve, Ku, LZ, NB, Ni, NK, No, NS, Ok, Om, SB, SK, SS, Tm_HM, Tm_Tb, Tm_Ya, To, Ty, Us, UZ, Yk_ Al, Yk_Ar, Yk_Vi.

Prim: IS 2; Vorobyov (1954) reported its penetration into the natural phytocenoses; reported from meadows and grazing grounds, along roads and on railway embankments (Tolmachev 1966); nowadays, very common, grows in roadsides, in fields, fallow fields, in some places penetrates into dry meadows, trampled areas, forest clearings and forests; Sakh: IS 2-3; reported from all districts of Sakhalin Island, in disturbed habitats, including coastal communities (Barkalov \& Taran 2004), a common species for Kuril Islands (Fukuda et al. 2014); Khab: IS 4; naturalized long ago, common, prevalent, including in northern areas, where for some time it stays on felling sites, roadsides of logging roads; Amur: IS 2; Yak: IS ?; found before 1926 (Komarov 1926); prevalent except for the northwestern districts and the catchment area of the Kolyma River, along the Lena River enters the Arctic Region to a limited extent; probably a native meadow species behaving as an aggressive ruderal and pasture weed (Nikolin 2016); Mag: IS 2; agriophyte, colonizes roadsides, waste grounds, lawns, trampled artificial meadows, fallow fields, gold mining tailings, disturbed dwarf birch, alder and dwarf-pine forests, pebble deposits (Lysenko 2012); Kam: IS 2; prevalent species, common in disturbed habitats, including thermal grounds, forest margins and meadows (Chernyagina \& Devyatova 2018); Chuk: IS ?; towns Provideniya and Ureliki; in river valleys and as a weed species in populated areas next to houses, in kitchen gardens, in roadside areas, on waste grounds.

\section{Vicia tetrasperma (L.) Schreb.}

Distribution in Asian Russia: Al, GA, Ha, Ir_An, Ir_Pr, $\mathrm{Ke}, \mathrm{Kr} \_\mathrm{Pu}, \mathrm{Kr} \_\mathrm{Ta}, \mathrm{Kr} \_\mathrm{TN}, \mathrm{Kr} \_\mathrm{Ve}, \mathrm{Ku}, \mathrm{LZ}, \mathrm{NB}, \mathrm{No}, \mathrm{Om}$, SB, SS, Tm_HM, Tm_Tb, Tm_Y $a$, To, Ty, Us.

Prim: IS 2-3; until the end of the 20th century was considered a rare species, reported from Vostochny Harbour in Nakhodka Municipality (Nechaeva 1998); at the beginning of the 21st century began to spread quickly; near the city of Nakhodka within the area up to 5-10 $\mathrm{m}$ from the edge of roads it is reported in large numbers on artificial meadows, in shrub communities and in forest margins; was also reported on seashore meadows in Kievka Bay of Lazovsky District and on meadows near the town Ternei; Khab: occurs rarely on waste grounds and railway embankments, not included in the list of invasive species.

\section{GENTIANACEAE}

Centaurium pulchellum (Sw.) Hayek ex Hand.-Mazz., Stadlm., Janch. \& Faltis.

\section{Distribution in Asian Russia: Us.}

Prim: IS 2; known on a seashore meadow at Ugolnya station near Vladivostok and on railways near Sibirtsevo station (Nechaeva 1998); later it was mentioned for the Russkyi and Popov Islands (Nedoluzhko \& Denisov 2001), nowadays, it is abundant on Russkyi Island on sand flats in the Novik Bay and on dry meadows and loamy areas not covered by grass on mountain passes between bays; rare species, reported from wet seashore salt marsh meadows and seaside sand and mud flats near Nakhodka; Khab: known from one habitat, not included in the list of invasive species.

\section{HYPERICACEAE}

\section{Hypericum perforatum $\mathrm{L}$.}

Distribution in Asian Russia: Al, GA, Ir_An, Ke, Kr_Ve, $\mathrm{Ku}, \mathrm{No}, \mathrm{NS}, \mathrm{Om}, \mathrm{SB}, \mathrm{SK}, \mathrm{SS}, \mathrm{Tm} \_\mathrm{Tb}$, To, Us.

Prim: IS 2; on pebble and in shrub communities along the Sukhodol River (Kangauz) and its tributaries (Vorob'ev 1964), on railway tracks near Ryazanovka station; Sakh: IS 2; reported from some districts of central and southern Sakhalin (Barkalov \& Taran 2004), reported in 2010 from Shikotan Island, in 2011 from Iturup Island (Fukuda et al. 2014).

\section{HYDROCHARITACEAE}

\section{Elodea canadensis Michx.}

Distribution in Asian Russia: Ch_Sh, Ir_An, $\mathrm{Kr} \_\mathrm{Ve}, \mathrm{Ku}$, Tm_Tb, Yk_Al.

Bur: IS 1; several habitats in Northern Baikal and Kabansk Districts, where this species actively penetrates into the natural communities, modifying the appearance of natural ecosystems and acts as a dominant species (Ebel et al. 2016); Zab: IS 3; first found in Kenon Lake (city Chita) in the catchment area of the Amur River in 2009; in the near future, the expansion of this species in the Russian Far East is expected (Ebel et al. 2016); Yak: IS ?; first reported in 2010 from the village Oi (Nemyugyuntsy) of Khangalass Ulus (Bobrov et al. 2017); in 2015, collected also near the 
city of Lensk; in all cases the plant was encountered lakes in former river beds and river ducts overgrown with grass along the Lena River; potentially dangerous and aggressive species (Nikolin 2016).

\section{IRIDACEAE}

\section{Sisyrinchium septentrionale E.P. Bicknell}

Distribution in Asian Russia: Ir_An, NB, SB, Us.

Prim: IS 2; along roads, also penetrates into the meadows; Khab: IS 2; first collected in 1960s near Khabarovsk from population that exists now; in southern districts, spreads widely invading seminatural and natural communities of shrubs, meadows, margins of broad-leaved forests by forming large clones; occasionally cultivated but often freezes out.

\section{JUNCACEAE}

\section{Juncus tenuis Willd.}

Distribution in Asian Russia: Bu, Ch_Sh, Ir_An, NB, SK, Us.

Prim: IS 2-3; first collected near Vladivostok in 1960 (Nechaeva 1998); nowadays, prevalent species occurring in roadsides, on artificial meadows, trampled places, along the forest trails; Sakh: IS ?; occurs on Kunashir and Iturup Islands (Fukuda et al. 2014); Khab: IS 4; occurs in roadsides, on artificial meadows, on trampled places, along the forest trails; Bur: IS 4 (Ebel et al. 2016).

\section{LAMIACEAE}

\section{Galeopsis ladanum L.}

Distribution in Asian Russia: Al, Am, Bu, GA, Ha, Ir An, Ka, Ke, Kr_Ve, Ku, No, Ok, Om, SB, SS, Tm_Tb, To, Ty, Us, Yk_Al, Yk_Vi.

Prim: IS 2-3; on railway embankments, waste grounds, in roadsides; penetrates into sand and pebble deposits along the rivers; Sakh: IS ?; reported from Tymsky and Western Sakhalin districts of Sakhalin Region (Barkalov \& Taran 2004); Khab: prevalent, but occurs sporadically, exclusively in secondary habitats; not included in the list of invasive species; Yak: IS ?; first reported by Karavaev (Tolmachev 1974) from upper reaches of the Lena River; according to the data of Kuznetsova and Zakharova (Cherosov 2012) new places of successful emergency of populations have not been idicated with the only notion of species in Aldan District in fallow fields; potentially dangerous weed (Nikolin 2016) but not very active; Mag: IS ?; ephemerophyte; landfills, crops of perennial grasses, gold mining tailings (Lysenko 2012); apart from that, in Magadan Region Galeopsis bifida Boenn. is an active weed; Kam: rarely, in Ust-Kamchatsk and Ust-Bolsheretsk Disricts, next to dwellings and along roads (Yakubov \& Chernyagina 2004).

\section{Glechoma hederacea L.}

Distribution in Asian Russia: Al, Am, Bu, GA, Ha, Ir_An, Ir_Pr, Ka, Ke, Kr_Ve, LZ, No, Ok, SS, To, Ty, Us, Yk__Vi.

Prim: IS 3; does not invade seminatural and natural communities; according to Probatova (1993), the genus in the Far East is represented by native species, G. longituba; alien $G$. hederacea is very rare; the identification of the species is complicated due to the seasonal variation of features and possibly the hybrid "absorption" of the alien species by the local one; Sakh: IS 4; only in culture; Khab: IS 2; widely used as an ornamental and a ground-covering plant; escapes from culture and occupies lawns, roadsides, fallow fields, penetrates into the rills, road ditches, floodplains of small rivers (Antonova 2012); Jew: IS 1; Amur: IS 4; epecophyte; occurs as a weed on railway embankments, in abandoned kitchen gardens (Aistova 2009); Yak: IS ?; first mentioned by Karavaev (1958); rare; valley of the upper Lena River up to the city of Olyokminsk; no updates are available; potentially dangerous weed (Nikolin 2014); Mag: very rare on the lawns in Magadan (Mochalova \& Khoreva 2016); Kam: IS 3; occurs in Yelizovo and Milkovo Districts, mainly next to dwellings, everywhere escapes from culture (Chernyagina \& Devyatova 2018).

\section{OENOTHERACEAE}

\section{Oenothera biennis L.}

Distribution in Asian Russia: Al, Bu, Ke, Kr_Ve, Ku, LZ, Om, SK, SS, Tm_Tb, Us.

Prim: IS 2; prevalent in roadsides, on embankments, waste grounds, penetrates into the river pebbles, dry meadows, forest margins, stony slopes, seashore sands and pebble; Sakh: IS 2; reported for some districts of central and southern Sakhalin (Barkalov \& Taran 2004); abundant fruiting plants were observed on Cape Slepikovsky on Sakhalin Island in 2016 mainly along the railways, invading the adjacent meadows; occurs in Kunashir and Iturup Islands (Fukuda et al. 2014); Khab: IS 2; known since 1960s, often forms dense stands along roads, on stony slopes, spreads massively; Jew: IS 3; spreads massively along the roads; Amur: IS 2; epecophyte, first reported in 1988 by Kudrin (VLA); common on railway embankments, in roadsides, in cultivated crops (Aistova 2014).

\section{OROBANCHACEAE}

\section{Rhinanthus minor L.}

\section{Distribution in Asian Russia: Ka, SS, Us.}

Prim: IS 2; invades natural phytocenoses, dominates some types of meadows in Golubichnoye Urochishche (SikhoteAlin Nature Reserve) (Pimenova 2016); first found in 1951 in Partizansky District near the village Novaya Rudnaya (population does not exist anymore) and near the mountain pass from the village Mikhailovka to the village Ekaterinov$\mathrm{ka}$ on a wet grass meadow, in both cases in large groups (Vorob'ev 1954 as Rh. major L., 1964); Sakh: IS 2; reported from some districts of central and southern Sakhalin (Barkalov \& Taran 2004); Khab: IS 2; common mainly along the seashore, where becomes a part of disturbed and post-fire meadows in the place of the Larix cajanderi Mayr forests, sometimes occupying entire forest clearings; Kam: IS 2; prevalent, invades disturbed meadow communities and herb meadows (Chernyagina \& Devyatova 2018).

\section{OXALIDACEAE}

Xanthoxalis corniculata (L.) Small.

Distribution in Asian Russia: Bu, LZ, SS, Us.

Prim: does not invade seminatural and natural communities; Sakh: IS 4; only in the culture; Khab: IS 1; spreads massively, penetrates into the ruderal habitats and disturbed meadows (Antonova 2012); Jew: IS 2; Amur: individual specimens were found just recently.

\section{PLANTAGINACEAE}

\section{Linaria vulgaris Mill. s.1.}

Distribution in Asian Russia: Al, Am, Bu, Da, E_Al, GA, Ha, Ir_An, Ir_Pr, Ka, Ke, Kl, Kr_TN, Kr_Ve, Ku, LZ, NB, Nj, No, NS, Ok, Om, SB, SS, Tm_Tb, To, Ty, Us, UZ, Yk_Vi.

Prim: IS 2; prevalent, occurs along roads, on railway embankments, in fallow fields, penetrates into the meadows, 
shrub communities, dry stony slopes, sand and pebble deposits along rivers and seashore sands; Sakh: IS 2; reported from most districts of Sakhalin Island (Barkalov \& Taran 2004); Khab: naturalized long ago, spreads widely in roadsides, on sand and pebble deposits along rivers near populated areas, on waste grounds; does not invade seminatural and natural communities; not included in the list of invasive species; Amur: IS 2; epecophyte; at the beginning of the 20 th century was reported on meadows, river banks, in oak forests, margins of conifer forests, on dry meadows, less frequently near ploughland, in roadsides and populated areas; currently a prevalent plant of ruderal habitats, fields (Aistova 2009); Yak: IS ?; cited by Komarov (1926) and Tarabukin (1932); prevalent aggressive weed species (Nikolin 2016); Mag: IS 2; agriophyte; colonizes artificial meadows, roadsides, waste grounds, lawns, kitchen gardens, fallow fields, gold mining tailings, secondary willow stands, pebble deposits (Lysenko 2012); Kam: IS 3; occurs next to dwellings, in roadside areas, on lower parts of grassy southern slopes along roads, on barrier beaches at the seashore (Chernyagina \& Devyatova 2018).

\section{Odontites vulgaris Moench.}

Distribution in Asian Russia: Al, Am, Bu, Ch_Ka, Ch Sh, Da, GA, Ha, Ir_An, Ir_Pr, Ka, Ke, Kr_Ve, Ku, LZ, NB, No, Om, SB, SS, Tm_Tb, To, Ty, Us, Yk_Vi.

Prim: IS 2; along roads, on meadows, on the seashore; occurs also on railway embankments, waste grounds, grazing grounds, seashore meadows; Sakh: IS ?; reported from some districts of central and southern Sakhalin (Barkalov \& Taran 2004); Khab: IS 4; naturalized long ago, spreads widely in roadsides, in ruderal habitats, along village streets, forms part of ruderalized and disturbed natural meadows; Jew: IS 2; active on abandoned meadows, along the roads; Amur: IS ?; epecophyte; occurs on meadows, in shrub communities, as a weed in fallow fields, along the roads, in agricultural crops (Aistova 2009); Yak: IS ?; mentioned by Komarov (1926); probably a native species of forest, steppic meadows on calcareous bedrocks, which was initially considered rare (Karavaev 1958, Tolmachev 1974); currently, often occurs apart from natural habitats:in fallow fields, cattle yards, smallholdings, roadsides; abundant near Yakutsk; Kam: IS 3; occurs in disturbed habitats in Milkovo and Yelizovo Disricts (Chernyagina \& Devyatova 2018).

\section{Plantago major $\mathrm{L}$.}

Distribution in Asian Russia: Al, Am, AP, Bu, Ch, Ch_ Sh, Co, Da, E_Al, GA, Ha, Ir_An, Ir_Pr, Ka, Ke, Kl, Kre $\mathrm{Kr} \_\mathrm{Pu}, \mathrm{Kr} \_\mathrm{TN}, \mathrm{Kr} \_\mathrm{Ve}, \mathrm{Ku}, \overline{\mathrm{LZ}}, \mathrm{NB}, \mathrm{NK}, \mathrm{No}, \mathrm{NS}, \mathrm{Ok}$, Om, SB, SK, SS, Tm_HM, Tm_Tb, Tm_Ya, To, Ty, Us, UZ, Yk_Al, Yk_Vi, Yk_Ya.

Prim: does not invade seminatural and natural communities; Sakh: IS 2; reported from most districts of Sakhalin Island (Barkalov \& Taran 2004) and Kunashir Island (Fukuda et al. 2014); Khab: prevalent synanthropic species; not included in the list of invasive species; Amur: IS 3; Yak: IS ?; found before 1926 (Komarov 1926); prevalent in central and southern districts; probably invades YanoIndigirskaya Lowlands districts (Cherosov 2012); frequently occurs in natural phytocenoses (possibly a native plant): wet, sometimes alkaline riverside and lakeside meadows, often grows in small holdings, cattle yards, kitchen gardens; an aggressive weed species but considerable danger is not expected (Nikolin 2016); Mag: IS 2; agriophyte, colonizes waste grounds, roadside areas, trampled meadows, kitchen gardens, fallow fields, willow stands disturbed by human activity, gold mining tailings, pebble deposits, floodplain meadows, sedge fens in the places along rough gravel roads (Lysenko 2012); Kam: IS 2; common in all districts; colonizes thermal grounds apart from disturbed habitats (Chernyagina \& Devyatova 2018); Chuk: IS ?; Chukotka Upland (towns Komsomolsky, Dorozhny), eastern part of the peninsula (towns Provideniya, Senyavina and Gilmimliney hot springs), catchment area of the Anadyr River (city Anadyr, town Markovo), Koryak coast (Beringovskiy village); ruderal plant, occurs mainly next to dwellings, along roads, on pastures, occasionally on riverside and seashore sands and pebble deposits; demonstrates behavior of native species near thermal springs.

\section{Verbascum thapsus L.}

Distribution in Asian Russia: Al, GA, Ha, Ir_Pr, Ke, Kr_Ve, Ku, No, Om, SS, Tm_Tb, Us.

Prim: IS 2; is naturalized and occurs in large numbers in the floodplains of Partizanskaya, Kievka and Sukhodol Rivers, and in the valley of the Arsenyevka River near the village of Vinogradovka. Grows on river pebble deposits, along small rills and in many populated areas of these catchment areas (city of Partizansk, village of Lazo, village of Anisimovka, etc.) (Vorob'ev 1954, 1964). Reported on overgrowing pebble deposits and forest clearings and margins of floodplain forests along the Partizanskaya River. Sakh: IS 4; cited for Southern Sakhalin Plain (Barkalov \& Taran 2004); Khab: individual plants were found, not included in the list of invasive species.

\section{Veronica chamaedrys $\mathrm{L}$.}

Distribution in Asian Russia: Al, GA, Ha, Ir_An, Ka, Ke, Kr_Ve, Ku, No, NS, Om, SB, SK, SS, Tm_HM, Tm_Tb, Tm_Ya, To, Us.

Prim: IS 2; occurs mainly in the southern part, naturalized; common in valley forests and their margins; Sakh: IS 2; reported for most districts of central and southern Sakhalin (Barkalov \& Taran 2004), was encountered on Kunashir Island in the estuary of the Tyatina River (Fukuda et al. 2014); Khab: individual plants were found on lawns, not included in the list of invasive species; Kam: IS 2; reported from Petropavlovsk-Kamchatsky along roads, on herb meadows and in willow stands, does not spread massively, but grows along the trail in the Nalychevo Natural Park (Chernyagina \& Devyatova 2018).

\section{Veronica peregrina $\mathrm{L}$.}

\section{Distribution in Asian Russia: Us.}

Prim: IS 2; on grazing grounds and waste grounds (Nechaeva 1998). In Shkotovsky District, reported on meadows and in Alnus japonica forest; Khab: first collected 1966 in the village of Petropavlovka, occurs rarely on mud flats along the Amur River, is not included in the list of invasive species.

\section{Veronica scutellata L.}

Distribution in Asian Russia: Al, GA, Ha, Ir_An, Ka, $\mathrm{Kr} \_\mathrm{Pu}, \mathrm{Kr} \_\mathrm{TN}, \mathrm{Kr} \_\mathrm{Ve}, \mathrm{Ku}, \mathrm{No}, \mathrm{NS}, \mathrm{Om}, \mathrm{SK}, \mathrm{Tm} \_\mathrm{Tb}, \mathrm{To}$, Ty, Us, Yk_Vi.

Prim: IS 2; occurs frequently in floodplain forests near the village Chernigovka; Sakh: IS ?; reported for Tymsky District of Sakhalin Island (Barkalov \& Taran 2004); Khab: occurs rarely, primarily along wet roadsides, along the banks of water bodies in recreation zones, is not included in the list of invasive species; Yak: known from one locality: swamp grasslands and shrubs near Vilyuisky road, $180 \mathrm{~km}$ away from Yakutsk (collector R. Abolin, 1912 г.); the closeness of the road suggests introduction, but at that time the road was not used that intensely and mostly for animaldrawn traffic; later, the collections were not repeated; Kam: 
known from the only habitat in the town of Paratunka, in a roadside ditch (Chernyagina \& Devyatova 2018); does not pose danger as an invasive plant.

\section{POACEAE}

\section{Dactylis glomerata L.}

Distribution in Asian Russia: Al, Co, GA, Ha, Ir_An, Ir_Pr, Ka, Ke, Kr_Ve, Ku, NK, No, NS, Ok, Om, SB, SK, SS, Tm_Tb, To, Ty, Us.

Prim: IS 2; common along roads; reported also from forest clearings and margins; Sakh: IS 2; mentioned for some districts of central and southern Sakhalin (Barkalov \& Taran 2004) in meadows; grows on Kunashir Island (Fukuda et al. 2014); Khab: occurs mainly on lawns and along roads, is not included in the list of invasive species; Mag: IS ?; a colonophyte; lawns, along pavements (Lysenko 2012); Kam: IS 3; common next to dwellings and along roads (Chernyagina \& Devyatova 2018).

Elymus novae-angliae (Scribn.) Tzvel.

Distribution in Asian Russia: Al, Bu, Ch_Sh, GA, Ha, Ir_An, Ka, Kr_Ve, LZ, No, Om, SB, SK, Ty, Us.

Prim: does not invade seminatural and natural communities; Khab: IS 4; used as fodder and lawn plant, sometimes goes in wilderness and occurs on field boundaries, in fallow fields, roadside areas, on embankments and waste grounds, less frequently on steppe slopes; Jew: IS 4; Amur: IS 4; an ephemerophyte, a fodder plant, as a weed occurs in roadside areas, on embankments, on waste grounds (Aistova 2009); Mag: existing herbarium specimens under this name should be treated as a native weed species E. charkeviczii Probat. (Lysenko 2012); Kam: IS 3; occurs in Tigil, Bystrinsky and Yelizovo Districts in roadsides, fallow fields and on waste grounds (Chernyagina \& Devyatova 2018).

\section{Festuca pratensis Huds.}

Distribution in Asian Russia: Al, Bu, GA, Ha, Ir_An, Ir $\mathrm{Pr}, \mathrm{Ka}, \mathrm{Ke}, \mathrm{Kr} \_\mathrm{Pu}, \mathrm{Kr} \_\mathrm{TN}, \mathrm{Kr} \_\mathrm{Ve}, \mathrm{Ku}, \mathrm{NB}, \mathrm{NK}, \overline{\mathrm{N}}$, NS, Ok, Om, SB, SK, SS, Tm_HM, Tm_Tb, To, Ty, Us, Yk_Vi.

Prim: does not invade seminatural and natural communities; Sakh: IS ?; reported on Kunashir Island (Fukuda et al. 2014); Khab: IS 2; in 1960s was mentioned as a rare species in the Amur River region (Voroshilov 1966); currently occurs in fallow fields, along roads, in populated areas, various secondary and disturbed habitats (Antonova 2012); Jew: IS 2; Amur: IS 4; ephemerophyte (epecophyte), grows in Arkhara Distict (collections by S. Kudrin) (Aistova 2009); Yak: IS ?; listed by Komarov (1926); common in southern districts (upper Lena River), on floodplain and dry meadows, in fallow fields; Mag: IS ?; colonophyte, colonizes lawns, roadside areas, waste grounds; very rare (in the vicinity of the town of Seimchan) (Lysenko 2012); Kam: IS 3; a common species next to dwellings and in roadsides (Chernyagina \& Devyatova 2018).

\section{Hordeum jubatum L.}

Distribution in Asian Russia: An, AP, Bu, Ch, E_Al, Ha, Ir_An, Ka, Kl, Kr, Kr_Pu, Kr_TN, Ku, LZ, No, NS, Ok, Om, SB, SK, SS, Us, Yk_Al, Yk_Ar, Yk_Ko, Yk_Ol, Yk_ Vi, Yk_Ya.

Prim: IS 1; prevalent species along roads, on waste grounds, grazing grounds, penetrates wet halophilous seashore meadows; Sakh: IS 3; disturbed habitats mainly along the railways in the southern Sakhalin; Khab: IS 1; spreads massively in roadside areas and along railway tracks, forms dense massive stands along the banks of the Amur River (Antonova 2012); Jew: IS 1; Amur: IS 3; epecophyte, occurs in roadside areas, on lawns, railway embankments in Arkhara, Blagoveshchensk, Tambovsky Districts (Aistova 2009); Bur: IS 2; first collected in 1964 near Ulan-Ude; in 1973-1975, was mentioned for Kabansky District on railway embankments along the southern bank of Baikal, and later in Barguzin, Pribaikalsky, Ivolginsk, Severobaikalsky, Tunkinsky, Okinsky, Zakamensky, Bichursky Districts; currently is listed as an invasive species (Ebel et al. 2016); Zab: IS 3; first mentioned in 1990 for Sretensky District, later was collected in Dauria and in Chita (Ebel et al. 2016). Yak: IS ?; first collections in Yakutia are dated 1835 near the Aldan River (herbarium by N. Turchaninov, LE); those specimens were mentioned in the summary by K. Ledebur for "Flora Rossica", and collections were quite numerous; common in wooded tundra downstream of the Kolyma River; very active and acts as an aggressive ruderal weed, spreads along roads (Nikolin 2016); Mag: IS 2; epecophyte and an agriophyte, colonizes waste grounds, roadside areas, heavily trampled artificial meadows, kitchen gardens, rarely fallow fields, gold mining tailings, pebble deposits and disturbed floodplain meadows near populated areas; rare (Lysenko 2012); Kam: IS 3; occurs not only next to dwellings, but also on river beaches and pebble deposits, on dry thermal grounds; widely distributed in northern areas, where it forms monodominant communities in populated areas; (Chernyagina \& Devyatova 2018); Chuk: IS ?; typical anthropochore; settles roadsides, abandoned pebble deposits and polygons, abundant in settlements near homesites, in cattle-pens; in the south, often found on sand and pebble alluvia and sea coastal terraces; in tundra areas relatively rare; noted as alien on Wrangel Island (Yurtsev et al. 2010); common on the shore of Chaunskaya Bay, in the catchment area of the Anadyr River and Beringovskiy village (sea port); on deposits along river banks not covered by grass, on dry grassy slopes, in valley willow stands, sometimes next to dwellings.

\section{Pbleum pratense $\mathrm{L}$.}

Distribution in Asian Russia: Al, Am, Bu, Ch_Sh, Co, GA, Ha, Ir_An, Ir_Pr, Ka, Ke, Kr, Kr_Ve, Ku, LZ, NK, No, NS, Ok, Om, SB, SK, SS, Tm_Tb, To, Ty, Us, UZ, Yk_Al.

Prim: IS 2; Vorob'ev (1954) reported its penetration into the natural phytocenoses; reported from crops and as a wildling on meadows and along roads (Tolmachev 1966); currently prevalent species, often occurs in populated areas, along roads, in fallow fields and fields, penetrates into the meadows, forest clearings and margins, floodplain forests and Alnus japonica forests; Sakh: IS 1-2; reported for most districts of Sakhalin Island, where it invaded the meadow plant communities (Barkalov \& Taran 2004), a common species on Kunashir and Iturup Islands (Fukuda et al. 2014); Khab: in fallow fields, on lawns, along roads, in fields, populated areas, is not included in the list of invasive species; Yak: IS 2; first reported by Karavaev (1958) as a very rare alien cultivated species in the valley of Aldan River (from the riverhead up to the vicinity of the town Khandyga); currently frequently reported from the same area, on roadside meadows up to the vicinity of the town of Chulman and in Upper Lena River floristic area (Cherosov 2012); shows moderate activity, does not pose serious threats; Mag: IS ?; epecophyte and an agriophyte; occurs in artificial meadows, fallow fields, lawns, roadside areas, rarely in disturbed floodplain meadows; rare (Lysenko 2012); Kam: IS 3; common synanthrope; occurs in disturbed habitats (Chernyagina \& Devyatova 2018).

\section{Poa annua L.}

Distribution in Asian Russia: Am, Bu, Co, Da, E_Al, Ha, $\mathrm{Ka}, \mathrm{Kr} \_\mathrm{TN}, \mathrm{Kr} \_\mathrm{Ve}, \mathrm{LZ}, \mathrm{Nj}, \mathrm{NK}, \mathrm{NS}, \mathrm{Ok}, \mathrm{SK}, \mathrm{SS}, \mathrm{Ty}, \mathrm{Us}, \mathrm{UZ}$. 
Prim: IS 2; prevalent species, occurs in populated areas, along roads, on grazing grounds and in fallow fields, on riverside sands and pebble deposits; Sakh: IS 2-3; reported for most districts of Sakhalin Island (Barkalov \& Taran 2004) in disturbed habitats and meadow margins; a common species on Kunashir and Iturup Islands (Fukuda et al. 2014); Khab: the species introduced at the initial stages of the region's exploration and colonized all suitable ecological niches, no invasion trends to seminatural and natural communities are observed; Yak: known from Komarov (1926); Karavaev (1958) mentioned it as a very rare ruderal species, common in the valley of the Lena River (upper part) and Aldan floristic area, along wet trails, forest roads, close to residential areas and rivers (easily becomes a weed); since that time, the prevalence of the species has not increased (maybe even decreased); Mag: IS ?; epecophyte; occurs in roadsides, lawns, waste grounds, trampled artificial lawns, on islands may go over to bird colonies; rare (Lysenko 2012); Kam: IS 3; prevalent synanthropic species (Chernyagina \& Devyatova 2018).

\section{Poa compressa $\mathrm{L}$.}

Distribution in Asian Russia: Bu, Ch, Ir_An, Ka, LZ, NS, SK, SS, Us.

Prim: IS 2; Vorob'ev (1954) reported its penetration in natural phytocenoses (without clarification); currently, common in roadsides, railway tracks, grazing grounds, penetrates through trampled places into forest clearings and oak forests, through seashore meadows on Russky Island; Sakh: IS ?; reported from some districts of northern and southern Sakhalin (Barkalov \& Taran 2004); Khab: IS 4; first found near Khabarovsk and village Gaiter (Probatova 1971); occurs along the roads, on railway embankments, on loamy and crushed stony eroded slopes; recently has become more common near campsites; Kam: IS 3; occurs in the populated areas of Yelizovo District; (Chernyagina \& Devyatova 2018); Chuk: IS ?; Provideniya Bay, surroundings of Emma Harbour, next to an old landfill.

\section{ROSACEAE}

\section{Alchemilla subcrenata Buss.}

Distribution in Asian Russia: Co, GA, Ir_An, Ka, Kr_ TN, Kr_Ve, NS, SB, To, Ty.

Sakh: IS ?; reported from Tymsky District of Sakhalin Island (Barkalov \& Taran 2004); Kam: IS 3; occurs in Aleutsky, Yelizovo, Milkovo and Ust-Bolsheretsk Districts; near dwellings, on lawns, grazing grounds, along the trail in Nalychevo Nature Park; on Bering Island in herb meadows on seashore terraces; agriophyte, xenophyte.

\section{Microcerasus tomentosa (Thunb.) Eremin et Juschev.}

\section{Distribution in Asian Russia: SS, Us.}

Prim: IS 2; widely cultivated; escapes from culture, goes in wilderness, is reported along roads, penetrates (rarely) cliffs and floodplain forests; Khab: IS 2; cultivated, occurs as a wild plant along roads, in places of former settlements, in disturbed forests near populated areas.

\section{Physocarpus opulifolia (L.) Maxim.}

Distribution in Asian Russia: SS, Us.

Prim: IS 3; widely cultivated; escapes from culture, goes in wilderness; reported from along the roads; Sakh: IS 4; reported for some districts of central and southern Sakhalin (Barkalov \& Taran 2004); Khab: used in landscaping, goes in wilderness very rarely; not included in the list of invasive species.

Potentilla multifida L. s. 1. (incl. P. tergemina Soják).

Distribution in Asian Russia: Al, AP, Ch_Ka, Ch_Sh,
Da, GA, Ha, Ir_An, Ir_Pr, Ka, Ke, Kr, Kr_Ve, NB, Nj, No, Ok, Om, SB, Tm_Tb, To, Ty, Us, UZ, Yk_Al, Yk_Vi.

Prim: IS 2-3; in populated areas, on railway tracks, along roads, on grazing grounds, on sands and pebble deposits along the banks of rivers and lakes, on cliffs; Khab: prevalent species; a native species, which naturalized well (or which has expanded its range) that colonizes various types of secondary habitats, but does not invade seminatural and natural communities (Antonova 2012); not included in the list of invasive species; Amur: IS 4; Yak: IS ?; found before 1926 (Komarov 1926); often occurs in central, southern and northeastern districts, along the Lena River goes far north; grows on steppe and stony slopes of river valleys, low ridges above floodplains, in meadow steppes, shrub communities, in forest margins; often behaves as a ruderal weed in roadsides, smallholdings, cattle yards; moderately aggressive weed species (Nikolin 2016); Mag: IS 2; agriophyte, colonizes waste grounds, roadside areas, pebble deposits; very rare (Lysenko 2012); Kam: IS 3; epecophyte (Chernyagina \& Devyatova 2018); Chuk: IS ?; Emma Harbour in Provideniya Bay, along a road; in the streets and other anthropogenic ecotopes of the towns of Egvenkinot and Provideniya.

\section{Potentilla norvegica $\mathrm{L}$.}

Distribution in Asian Russia: Al, Am, An, AP, Bu, Ch, Ch_Ka, Ch_Sh, Co, Da, E_Al, Ha, Ir_An, Ir_Pr, Ka, Ke, $\mathrm{Kl}, \mathrm{Kr}, \mathrm{Kr} \mathrm{P}_{-} \mathrm{Pu}, \mathrm{Kr} \mathrm{T}_{\mathrm{TN}}, \mathrm{Kr}_{-} \mathrm{Ve}, \mathrm{Ku}, \mathrm{LZ}, \mathrm{NB}, \mathrm{Nj}, \mathrm{NK}, \mathrm{No}$, NS, Ok, Om, SB, SK, SS, Tm_HM, Tm_Tb, Tm_Ya, To, Ty, Us, UZ, Yk_Al, Yk_Vi, Yk_Ya.

Prim: IS 2-3; in populated areas. along roads, on waste grounds, along river banks; Sakh: IS ?; reported from most districts of Sakhalin Island (Barkalov \& Taran 2004); Khab: likely a native species (apophyte), is not included in the list of invasive species; Yak: IS 4; found before 1926 (Komarov 1926); common in all districts except northwestern and Arctic regions; colonizes river banks and roadside areas; usually not numerous in communities; moderately aggressive ruderal weed; Mag: IS 2; agriophyte; waste grounds, roadside areas, kitchen gardens, fallow fields, trampled artificial meadows, weeds in greenhouses, gold mining tailings, pebble deposits, floodplain willow stands; Kam: IS 4; in all districts; next to dwellings, along river banks, on dry thermal grounds; epecophyte, xenophyte (Chernyagina \& Devyatova 2018); Chuk: IS ?; near town Egvenkinot (town Komsomolsky), Gulf Kresta, middle Anadyr river basin (Markovo); weed (Yurtsev et al. 2010).

\section{Rubus idaeus $\mathrm{L}$.}

Distribution in Asian Russia: Al, GA, Ha, Ir_An, Ka, Ke, Kr_Ve, No, SB, Tm_HM, Tm_Tb, To, Ty, Us.

Prim: IS 2-3; escapes from culture, goes in wilderness; reported from along roads, rarely from moist forests (encountered in Alnus japonica forests); Khab: for several years may remain in the places where it had been cultivated previously, not included in the list of invasive species; Kam: IS 3; occurs on abandoned garden allotments, near apartment blocks, on slopes along roads, on waste grounds in Yelizovo, Milkovo, Tigil and Olyutorsky Disricts; (Chernyagina \& Devyatova 2018).

\section{RUBIACEAE}

\section{Galium aparine s.1.}

(incl. G. vaillantii DC. and G. spurium L.)

Distribution in Asian Russia: Ch, Ch_Sh, Ir_An, Ir_Pr, $\mathrm{Ka}, \mathrm{Ok}, \mathrm{SB}, \mathrm{SS}, \mathrm{Us}, \mathrm{Yk} \_\mathrm{Vi}$.

Prim: IS 2; prevalent, occurs along roads, on railway em- 
Table 1. Taxonomic analysis of invasive species of the Far Eastern Federal District.

\begin{tabular}{|c|c|c|c|c|c|}
\hline \multirow[t]{2}{*}{ Family } & \multirow{2}{*}{$\begin{array}{l}\text { The } \\
\text { number } \\
\text { of genera }\end{array}$} & \multirow{2}{*}{$\begin{array}{c}\text { The } \\
\text { number } \\
\text { of species }\end{array}$} & \multicolumn{3}{|c|}{$\begin{array}{c}\text { Number of } \\
\text { species by } \\
\text { invesiveness } \\
\text { status* }\end{array}$} \\
\hline & & & IS 1 & $\begin{array}{c}\text { IS } \\
2\end{array}$ & $\begin{array}{c}\text { IS } \\
3\end{array}$ \\
\hline Aceraceae & 1 & 1 & 1 & & \\
\hline Amaranthaceae & 1 & 1 & & & 1 \\
\hline Apiaceae & 5 & 5 & 2 & 1 & 2 \\
\hline Asteraceae & 26 & 33 & 8 & 21 & 4 \\
\hline Balsaminaceae & 1 & 2 & 1 & 1 & \\
\hline Boraginaceae & 3 & 3 & 1 & 1 & 1 \\
\hline Brassicaceae & 12 & 12 & & 9 & 3 \\
\hline Campanulaceae & 1 & 1 & & & 1 \\
\hline Cannabaceae & 2 & 2 & 1 & 1 & \\
\hline Caryophyllaceae & 4 & 4 & & 4 & \\
\hline Convolvulaceae & 1 & 1 & & 1 & \\
\hline Cucurbitaceae & 1 & 1 & 1 & & \\
\hline Cuscutaceae & 1 & 2 & 1 & 1 & \\
\hline Dipsacaceae & 1 & 1 & & 1 & \\
\hline Elaeagnaceae & 1 & 1 & 1 & & \\
\hline Euphorbiaceae & 1 & 1 & & & 1 \\
\hline Fabaceae & 8 & 12 & 1 & 9 & 2 \\
\hline Gentianaceae & 1 & 1 & & 1 & \\
\hline Hypericaceae & 1 & 1 & & 1 & \\
\hline Hydrocharitaceae & 1 & 1 & 1 & & \\
\hline Iridaceae & 1 & 1 & & 1 & \\
\hline Juncaceae & 1 & 1 & & 1 & \\
\hline Lamiaceae & 2 & 2 & 1 & 1 & \\
\hline Oenotheraceae & 1 & 1 & & 1 & \\
\hline Orobanchaceae & 1 & 1 & & 1 & \\
\hline Oxalidaceae & 1 & 1 & 1 & & \\
\hline Plantaginaceae & 5 & 7 & & 7 & \\
\hline Poaceae & 6 & 7 & 1 & 5 & 1 \\
\hline Rosaceae & 5 & 6 & & 4 & 2 \\
\hline Rubiaceae & 1 & 1 & & 1 & \\
\hline Solanaceae & 1 & 1 & & 1 & \\
\hline Vitaceae & 1 & 1 & & 1 & \\
\hline Total & 99 & 116 & 22 & 76 & 18 \\
\hline
\end{tabular}

Note: ${ }^{*}$ - the highest status in any of the regions bankments, streets of populated areas, penetrates pebble deposits and sandy banks along rivers and along the seashore; Sakh: IS ?; noted for Sakhalin Island (Voroshilov 1982), later mentioned for some districts of central and southern Sakhalin (Barkalov \& Taran 2004); Khab: IS 3; forms dense stands along small rivers within populated areas; Amur: IS 3; epecophyte, a plant of ruderal habitats, rarely occurs in crops (Aistova 2009); Zab, Bur: IS 2; spreads massively and naturalizes in disturbed seminatural and natural habitats (Ebel et al. 2016); Yak: IS 4; found before 1926 (Komarov 1926); occurs within the valley of the Lena River, approximately from Yakutsk (sometimes is introduced farther north) up to Olyokminsk; reported from fields, kitchen gardens, roadsides, next to dwellings, on the steep banks of the Lena River; potentially dangerous invasive weed (Nikolin 2016); Mag: IS 3; epecophyte, colonizes artificial meadows, kitchen gardens, potato fields, annual grass crops, gold mining tailings; rare (Lysenko 2012); Kam: IS 3; epecophyte; occurs in Olyutorsky, Tigil and Bystrinsky Districts (Chernyagina \& Devyatova 2018); Chuk: IS ?; Emma Harbour in Provideniya Bay; along roads in populated areas.

\section{SOLANACEAE}

Solanum nigrum $\mathrm{L}$.

Distribution in Asian Russia: Al, Bu, Ch_Sh, GA, Ha, Ir_An, Ir_Pr, Ke, Kr_Ve, Ku, LZ, No, Ok, Om, SK, SS, Tm_HM, Tm_Tb, To, Us.

Prim: IS 2; prevalent species in populated areas, dumpsites, kitchen gardens, along roads, penetrates river banks, seashore sands, was encountered in a floodplain forest (city Spassk-Dalny); Sakh: IS ?; reported from some districts of central and southern Sakhalin (Barkalov \& Taran 2004), occurs in disturbed habitats around populated areas on Iturup Island (Fukuda et al. 2014); Khab: common plant of ruderal habitats, especially those rich in nitrogen, does not invade seminatural and natural communities (Antonova 2012); not included in the list of invasive species; Amur: IS 2; epecophyte, on dumpsites, occasionally along river and lake banks; prevalent weed of secondary habitats and crops (Aistova 2009); Mag: IS ?; ephemerophyte; colonizes landfills, ruins, kitchen gardens; very rare (Lysenko 2012).

Table 2. The number of most aggressive invasive species of the Far Eastern Federal District, which are included in the group with status 1 (transformers) in at least one region. "yes" - the species is noted, but does not reach generative age; "no" - the species was not found; empty cells - no data.

\begin{tabular}{|c|c|c|c|c|c|c|c|c|c|c|c|}
\hline \multirow{2}{*}{ Family } & \multirow{2}{*}{ Species/district } & \multicolumn{10}{|c|}{ Subjects of Russian Federation } \\
\hline & & Prim & Sakh & Khab & Jew & Amur & Bur & $\mathrm{Zab}$ & Yak & Mag & Kam \\
\hline Aceraceae & Acer negundo & 1 & 2 & 1 & 2 & 2 & 4 & & no & yes & 2 \\
\hline Apiaceae & Heracleum sosnowskyi & & 3 & no & & & & & no & no & 1 \\
\hline Apiaceae & Pastinaca sylvestris & 3 & & 1 & 1 & 4 & 4 & & yes & no & \\
\hline Asteraceae & Ambrosia artemisiifolia & 1 & yes & 1 & 1 & 1 & no & no & no & yes & no \\
\hline Asteraceae & Bidens frondosa & 1 & & 1 & 1 & 2 & & & no & no & no \\
\hline Asteraceae & Cirsium setosum & 1 & yes & 2 & 1 & 3 & & & аб & 3 & 3 \\
\hline Asteraceae & Galinsoga parviflora & 2 & yes & 1 & 1 & 3 & & & no & no & no \\
\hline Asteraceae & Phalacroloma annuum & 1 & yes & 3 & 4 & 4 & & & no & no & no \\
\hline Asteraceae & Solidago canadensis & 1 & yes & 1 & 1 & 4 & no & no & no & no & 4 \\
\hline Asteraceae & Solidago gigantea & 1 & yes & yes & & & & & no & no & 4 \\
\hline Asteraceae & Sonchus oleraceus & 2 & yes & yes & & & & & 1 & no & yes \\
\hline Balsaminaceae & Impatiens glandulifera & 1 & yes & 1 & 1 & 3 & 3 & 4 & no & no & 1 \\
\hline Boraginaceae & Symphytum caucasicum & 2 & & 1 & & & & & no & no & 2 \\
\hline Cannabaceae & Humulus lupulus & yes & yes & 1 & 1 & 3 & & & no & no & yes \\
\hline Cucurbitaceae & Echinocystis lobata & 2 & yes & 1 & 1 & 2 & 4 & 4 & yes & no & yes \\
\hline Cuscutaceae & Cuscuta campestris & yes & & yes & & 1 & no & yes & no & no & no \\
\hline Elaeagnaceae & Hippophae rhamnoides & 2 & & 1 & 2 & 1 & & & no & no & 4 \\
\hline Fabaceae & Lupinus polyphyllus & no & yes & yes & & & 3 & no & no & no & 1 \\
\hline Hydrocharitaceae & Elodea canadensis & & & no & & & 1 & 3 & yes & no & no \\
\hline Lamiaceae & Glechoma hederacea & 3 & & 2 & 1 & 4 & & & yes & no & 3 \\
\hline Oxalidaceae & Xanthoxalis corniculata & yes & & 1 & 2 & yes & & & no & no & no \\
\hline Poaceae & Hordeum jubatum & 1 & & 1 & 1 & 3 & 2 & 3 & yes & 2 & \\
\hline
\end{tabular}




\section{VITACEAE}

\section{Parthenocissus inserta (A. Kerner) Fritsch.}

\section{Distribution in Asian Russia: Us.}

Prim: IS 2; cultivated, sometimes goes in wilderness; in the Akademgorodok of Vladivostok grows in a natural broad-leaved forest; in Spassk-Dalny was reported from floodplain forest; in Nakhodka was encountered in a suburb near the road; Khab: IS 2; recently has been widely used as an ornamental plant; occurs on lawns, ruderal habitats not far from the places where it is cultivated, in shrub communities in forest margins in populated areas; status 1 can be predicted for nearest future.

Thus, the invasive fraction of the flora of the Far Eastern Federal District includes 116 species belonging to 99 genera from 32 families (Table 1). Families Asteraceae (33 species), Fabaceae (12 species), Brassicaceae (12 species), Poaceae (7 species) and Plantaginaceae (7 species) have most invasive species. Eight families, in which the number of species in a family exceeds an average, include $74.1 \%$ of the invasive component. The average number of species in a family is 3.6, in a genus - 1.2; average number of genera in a family is 3.1 .

Eighteen species are only beginning to invade natural cenoses and are listed in the group with invasion status 3; 76 species actively invade natural cenoses of the territory and are listed in the group with status 2 (Table 2). Twentytwo species with invasion status 1 are transformer species. However, due to a strong inhomogenuity of the soil and climate conditions in the region a species is quite rarely considered a transformer in more than one territorial subject of the FEFD. Ambrosia artemisiifolia is considered a transformer species in 4 regions, Bidens frondosa, Solidago canadensis, Impatiens glandulifera and Hordeum jubatum - in 3 regions, other species transformed landscapes in one or two territorial subjects of the FEFD. The Asteraceae family is most rich in transformer species (8 species). Two species belong to the Apiaceae family, and the rest of transformer species belong to different families.

\section{CONCLUSION}

Because of a very strong heterogeneity of the soil and climate conditions there is considerable disparity in the list of alien species between various FEFD territorial subjects. Many species that actively colonize southern districts do not occur in the north, or only individual plants are reported and they are not capable of reproduction. In general, the problem of the spread of invasive species in the Far East is not yet as urgent as in Europe. However, one must take measures to control invasive species not when they have transformed the plant community - it is virtually useless then - but when alien species only begin spreading actively. It was proved long ago that this approach is more costeffective. That is why, the authors included in the list of the species of the future Black Book of the Far East ALL species, which tend to naturalize more than in one region, irrespectively of the area of their invasive range. This will help take concrete measures to prevent and mitigate the invasion of alien species.

This article is a necessary stage in the creation of the Black Book of the Far East flora, and the authors hope that a large-scale programme to study the spread and impact of invasive species on the current state of the ecosystems of the Far East will begin as early as this year in order to prevent the economic and environmental damage to the natural biodiversity of the region.

\section{ACKNOWLEDGEMENTS}

The work was carried out in accordance to MBG RAS Institutional research project № 19-1190805900359, research project of Botanical Garden-Institute FEB RAS (№AAAA-A17-117021310193-7) and Institute of Biological Problems of the North FEB RAS (AAAA-A17-117122590002-0).

\section{LITERAT URE CITED}

Abramova, L.M. 2013. Expansion of alien plant species in the Southern Urals (Republic of Bashkortostan): analysis of causes and environmental threats. Ecologia 5:324-330 (in Russian). [Абрамова А.M. 2013. Экспансия чужеродных вилов растений на Южном Урале (Республика Башкортостан): анализ причин и экологических угроз // Экология. № 5. С. 324-330].

Abramova, L.M., O.A. Chernyagina \& E.A. Devyatova 2017. Invasive species in Kamchatka: distribution and communities. Botanica Pacifica 6(1):3-12.

Aistova, E.V. 2009. Synopsis of adventive flora of the Amur region. Turczaninowia 12(1-2):17-40 (in Russian). [Аистова Е.В. 2009. Конспект аАвентивной фморы Амурской области // Turczaninowia. Т. 12, № 1-2. С. 17-40].

Aistova, E.V., V.G. Bezborodov, E.V. Gus'kova \& D.Yu. Rogatnykh 2014. Formation of trophic relations of native leaf-beetle species (Coleoptera, Chrysomelidae) with Ambrosia artemisiifolia (Asteraceae) in Primorsky Territory of Russia. Zoologicheskii Zhurnal 93(8):960-966 (in Russian with English summary). [Аистова Е.В., Безбородов В.Г., Гуськова Е.В., Рогатных А.Ю. 2014. Формирование трофических связей аборигенных видов жуков- иистоеАОв (Coleoptera, Chrysomelidae) с Ambrosia artemisiifolia (Asteraceae) в условиях Приморского края России // Зоологический журнац. Т. 93, № 8. С. 960-966].

Aistova, E.V. \& N.Yu. Leusova 2015. The genus Cuscuta L. in East Asia. Turczaninowia 18(2):111-128 (in Russian). [Аистова Е.В., Аеусова Н.Ю. 2015. РоА Cuscuta L. в Восточной Азии // Turczaninowia. Вып. 18, № 2. C. 111-128]

Andreeva, V. (ed.) 2014. Flora of Sakhalin. Apel'sin publishing house, Vladivostok, 172 pp. (in Russian). ГРастительный мир Сахалина / пол реА. В. Андреевой. 2014. ВАаАивосток: Иза-во Апельсин. 172 с.].

Anenkhonov, O.A. \& T.D. Pykhalova 2010. Flora summary of vascular plants of the Zabaykal'sk National Park. Publishing house of BNC SB RAS, Ulan-Ude, 228 pp. (in Russian). [Аненхонов О.А., Пыхалова Т.А. 2010. Конспект флоры сосудистых растений Забайкальского национального парка. УАан-УАэ: ИзА-во БНЦ СО РАН. 228 с.].

Anenkhonov, O.A. (ed.) 2001. Key to the plants from Buryatia. Respublikanskaya tipografiya, Ulan-Ude, 672 pp. (in Russian). [Определитель растений Бурятии / пол реА. О.А. Аненхонова. 2001. УАан-У Аэ: Республиканская типография. 672 с.].

Antonova, L.A. 2012. An invasive component of flora of Khabarovsky Territory. Rossiiskii Zhurnal Biologicheskikh Invazii 4:2-9 (in Russian with English summary). [Антонова А.А. 2012. Инвазионный компонент фморы 
Хабаровского края // Российский журнац биологических инвазий. № 4. С. 2-9].

Antonova, L.A. 2014. Adventive component of the flora of the sea coast of the Khabarovsky Territory. V.L. Komarov Memorial Lectures 62:63-105 (in Russian). [Антонова А.A. 2014. ААвентивный компонент флоры морского побережья Хабаровского края // Комаровские чтения. Вып. 62. С. 63-105].

Antonova, L.A. 2017. The current state of the alien component of the flora of the Khabarovsky Territory. Regional'nye Problemy (in Russian with English summary). [Антонова М.А. 2017. Современное состояние чужеродного компонента фморы Хабаровского края // Региональные проблемы. Т. 20, № 2. С. 5-12].

Antonova, L.A. 2018. New and seldom found of adventive species in the flora of the Khabarovsky Territory. Turczaninowia 21(3):97-101 (in Russian). [Антонова А.А. 2018. Новые и редко встречающиеся аАвентивные виды во флоре Хабаровского края // Turczaninowia. T. 21, № 3. C. 97-101].

Antonova, L.A., T.A. Rubtsova \& V.V. Gribkov 2015. Adventive component of the flora of the Bastak Reserve (Jewish Autonomous Region, Russian Far East). Biota $i$ sreda zapovednikov Dal'nego Vostoka 4:16-27 (in Russian). [Антонова А.А., Руббова Т.А., Грибков В.В. 2015. ААвентивный компонент флоры заповедника "Бастак" (Еврейская автономная об̆асть, Аальний Восток России) // Биота и среда заповедников Аальнего Востока. № 4. С. 16-27].

Baranova, O.G. (ed.) 2016. Black Book of flora of Udmurtia Republic. Institut komp'yuternykh issledovanii, Moscow, Izhevsk, 67 pp. (in Russian). [Черная книга фморы УАмуртской Республики / под ред. О.Г. Барановой. Москва; Ижевск: Институт компьютерных исследований, 2016. 67 с.].

Barkalov, V.Yu. \& A.A. Taran 2004. List of species of vascular plants of Sakhalin Island. In: Flora and fauna of Sakhalin Island (Materials of the International Sakbalin Project), part 1 (S.Yu. Storozhenko, ed.), pp. 39-66, Dal'nauka, Vladivostok (in Russian). [Баркалов B.Ю., Таран А.А. 2004. Список видов сосудистых растений острова Сахалин // Растительный и животный мир острова Сахалин (Материалы МежАународного саха^инского проекта), Ч. 1 / отв. реА. С.Ю. Стороженко. ВАаАивосток: Аальнаука. С. 39-66].

Barkalov, V.Yu., Vyshin I.B. \& S.S. Kharkevich 1993. First impressions of the vegetation cover of the Khanka State Nature Reserve. V.L. Komarov Memorial Lectures 41:114 140 (in Russian). [Баркалов В.Ю., Вышин И.Б., Харкевич C.C. 1993. Первые впечатления о растительном покрове Ханкайского государственного заповеАника // Комаровские чтения. Вып. 41. С. 114-140].

Bazarova, B.B. \& N.M. Pronin 2010. Elodea canadensis Michaux on the border of world watershed of Arctic and Pacific oceans. Rossiiskii Zhurnal Biologicheskikh Invarii 3:212 (in Russian with English summary). [Базарова Б.Б., Пронин Н.M. 2010. Elodea canadensis Michaux на границе мирового водораздела Аедовитого и Тихого океанов // Российский Журнал биологических инвазий. № 3. C. 2-12].

Beest, M., Esler, K.J. \& D.M. Richardson 2014. Linking functional traits to impacts of invasive plant species: a case study. Plant Ecology 216:293-305.

Berkutenko, A.N., D.S. Lysenko, M.G. Khoreva, O.A. Mochalova, A.N. Polezhaev, E.A. Andriyanova, N.V. Sinel'nikova \& V.V. Yakubov 2010. Flora and vegetation of Magadan
Region (summary of vascularplants and essay vegetation). Institut biologicheskikh problem Severa Dal'nevostochnogo otdeleniya Rossiiskoi akademii nauk, Magadan, 364 pp. (in Russian). [Беркутенко А.Н., Аысенко А.С., Хорева М.Г., Мочалова О.А., Полежаев А.Н., Андриянова Е.А., Синельникова Н.В., Якубов В.В. 2010 ФАора и растительность Магаданской области (конспект сосуАистых растений и очерк растительности). Магадан: ИБПС АВО РАН. 364 с.].

Bezdeleva, T.A. \& L.A. Fedina 2006. Vascular plants. In: Flora, vegetation and mycobiota Ussuri Reserve, pp. 79-134, Dal'nauka, Vladivostok (in Russian). [Безделева T.A., Федина И.А. 2006. Сосудистые растения // ФАора, растительность и микобиота заповедника "Уссурийский”. ВАадивосток: Аальнаука. С. 79-134].

Bobrov, A.A., V.A. Filippova, E.G. Nikolin \& E.V. Chemeris 2017. New to the flora of Yakutia Elodea canadensis, Hydrilla verticillata (Hydrocharitaceae) and Potamogeton maackianus (Potamogetonaceae). Botanicheskii Zhurnal 102(2): 222-231 (in Russian). [Бобров А.А., Филиппова B.A., Николин Е.Г., Чемерис Е.В. 2017. Новые Аля флоры Якутии Elodea canadensis, Hydrilla verticillata (Hydrocharitaceae) и Potamogeton maackianus (Potamogetonaceae) // Ботанический журнал. Т. 102, № 2. С. 222-231].

Boikov, T.G. (ed.) 1991. Flora of the Transbaikal National Park. BNC SB AS URRS, Ulan-Ude, 136 pp. (in Russian). [Фцора Забайкальского природного национального парка / под реА. Т.Г. Бойкова. 1991. УАан-УАэ: БНЦ CO AH CCCP. 136 c.].

Burdukovskaya, G.V. \& O.A. Anenkhonov 2009. Flora of Ivolga basin and its anthropogenic changes (Western Zabaykal'e). Publishing house of BNC SB RAS, Ulan-Ude, 267 pp. (in Russian). ББурдуковская Г.В., Аненхонов О.А. 2009. ФАора бассейна Иволги и ее антропогенные изменения (Западное Забайкалье). УАан-УАэ: ИзА-во БНЦ CO PAH. 267 c.].

Chernyagina, O.A. \& E.A. Devyatova 2018. Adventive plants of Kamchatka Territory: distribution and variety. In: Conservation of biodiversity of Kamchatka and adjacent seas: Reports of the XVII-XVIII international scientific conferences, vol. 51, pp. 92-101, Kamchatpress, PetropavlovskKamchatskii (in Russian). [Чернягина О.А., Аевятова Е.А. 2018. Адвентивные растения Камчатского края: распространение и разнообразие / / Сохранение биоразнообразия Камчатки и прилегающих морей: Аокмады XVII-XVIII межАународных научных конференций. Петропавловск-Камчатский: Камчатпресс. T. 51. C. 92-101].

Chernyagina, O.A. \& L.V. Shtreker 2012. Invasive species in the flora of Kamchatka. Estestvennye $i$ tekhnicheskie nauki 6(62):150-151 (in Russian). [Чернягина O.А., Штрекер А.В. 2012. Инвазивные виды во флоре Камчатки // Естественные и технические науки. № 6(62). С. 150-151].

Cherosov, M.M. (ed.) 2012. Check-list to the flora of Yakutia: Vascular plants. Nauka, Novosibirsk, 272 pp. (in Russian). [Конспект фморы Якутии / под реА. М.М. Черосова. 2012. Новосибирск: Наука. 272 с.].

Cherosov, M.M., N.P. Sleptsova, S.I. Mironova, P.A. Gololeva, B.N. Pestryakov \& L.D. Gavril'eva 2005. Syntaxonomy of synanthropic vegetation of Yakutia. YNC SB RAS, Yakutsk, 575 pp. (in Russian). ЧЧеросов М.М., Слепцова Н.П., Миронова С.И., Гоголева П.А., Пестряков Б.Н., Гавримьева $\Lambda . А .2005$. Синтаксономия синантропной растительности Якутии. Якутск: ЯНЦ СО РАН. 575 с.].

Chubar, E.A. 2015. Alien species in the small marine Island's Flora: life-strategic, coenotic activity, adventive index (The 
Far Eastern Marine Reserve, Primorskii krai).V.L. Komarov Memorial Lectures 63:128-163 (in Russian). [Чубарь E.A. 2015. Адвентивные виды сосудистых растений во флоре малых морских островов: типы стратегий, ценотическая активность, уровень адвентизации (на примере Аальневосточного морского заповедника, Приморский край) // Комаровские чтения. Вып. 63. C. 128-163]

Devyatova, E.A., O.A. Chernyagina \& L.M. Abramova 2016. Summary to the adventives flora of PetropavlovskKamchatsky city. Vestnik Severo-Vostochnogo Federal'nogo Universiteta im. Amosova 54(4):5-16 (in Russian). [Аевятова Е.А., Чернягина О.А., Абрамова А.М. 2016.

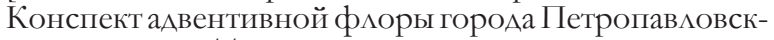
Камчатский // Вестник Северо-Восточного феАерального университета им. Амосова. Т. 54, № 4. C. 5-16].

Ellstrand, N.C. \& K.A. Schierenbeck. 2000. Hybridization as astimulus for the evolution of invasiveness in plants? Proceedings of the National Academy of Sciences of the United States of America 97:7043-7050.

Fomina, Z.V. 1965. About new species of weed plants in the Ulan-Ude district of the Buryatia ASSR. Trudy Buryatskogo sel'skokhozyaistvennogo instituta. Agronomiya 18:62-66 (in Russian). [Фомина 3.B. 1965. О новых вилах сорных растений в УАан-УАэнском районе Бурятской АССР // Труды Бурятского сельскохозяйственного института. Агрономия. Вып. 18. С. 62-66].

Foxcroft, L.C., D.M. Richardson, P. Pyšek \& P. Genovesi 2013. Plant invasions in protected areas: patterns, problems and challenges. Springer, Dordrecht, Heidelberg, New York, London, 656 pp.

Fukuda, T., M.A. Antipin, A.E. Loguntsev, I.G. Bobyr', A.A. Taran, O.A. Chernyagina \& H. Takhakasi 2015. Alien plants of the South Kuril Islands. In: Conservation of the biodiversity of Kamchatke a and the adjacent seas: Reports of the XV international scientific conferences, pp. 109-129, Kamchatpress, Petropavlovsk-Kamchatskii (in Russian). [Фукуда Т., Антипин М.А., Аогунцев А.Е., Бобырь И.Г., Таран А.А., Чернягина О.А., Тахакаси Х. 2015. Заносные растения Южных курильских островов // Сохранение биоразнообразия Камчатки и прилегающих морей: Аоклады XV международных научных конференций. Петропавцовск-Камчатский: Камчатпресс. С. 109-129].

Fukuda, T., Y. Kato, H. Sato, A.A. Taran, V.Yu. Barkalov \& H. Takahashi 2013. Naturalization of Cakile edentula (Brassicaceae) on the beaches of Kunashiri and Etorofu Islands - the first record for species from the Kuril Islands. Journal of Japanese Botany 88(4):124-128.

Fukuda, T., A. Taran, H. Sato, Y. Kato \& H. Takahashi 2014. Alien plants collected or confirmed on the islands of Shikotan, Kunashir and Iturup on the 2009-2012 botanical expeditions. Bulletin of the Hokkaido University Museum 7:8-26.

Gaertner, M., A. Den Bree, C. Hui \& D.M. Richardson 2009. Impacts of alien plant invasions on species richness in Mediterranean-type ecosystems: a meta-analysis. Progress in Physical Geograpby 33:319-338.

Gorovoi, P.G. \& V.G. Sakhno 1970. About two genera, new to the flora of the Soviet Far East. Novosti sistematiki vysshikh rastenii 7:304 (in Russian). [Горовой П.Г., Сахно В.Г. 1970. О Авух родах, новых Аля флоры советского Аальнего Востока // Новости систематики высших растений. Т. 7. С. 304].
Gular'yants, G.M. 2017. Anthropophytes of Dalnegorsk urban district. Byulleten' Botanicheskogo sada-instituta DVO RAN 17:1-20 (in Russian). [Гуларьянц Г.M. 2017. Антропофиты Аальнегорского городского округа // Бюм^етень Ботанического сада-института АВО РАН. Вып. 17. С. 1-20].

Hejda, M., P. Pysek \& V. Jarosík 2009. Impact of invasive plants on the species richness, diversity and composition of invaded communities. Journal of Ecology 97:393-403.

Hulme, P.E. 2003. Biological invasions: winning the science battles but losing the conservation war? Oryx 37:178-193.

Hulme, P.E. 2009. Trade, transport and trouble: managing invasive species pathways in an era of globalization. Journal of Applied Ecology 46:10-18.

Ivanova, M.M. \& M.G. Azovskii 1998. Floristic finds in Buryatia and Irkutsk Region. Botanicheskii Zhurnal 83(5):119124 (in Russian with English summary). [Иванова M.M., Азовский М.Г. 1998. ФАористические находки в Бурятии и Иркутской области / / Ботанический журнаА. Т. 83, № 5. С. 119-124].

Ivanova, M.M. 1991. Finds to the flora of the Pribaykalye and South Zabaykalye. Botanicheskii Zhurnal 76(7):10071016 (in Russian with English summary). [Иванова M.M. 1991. Находки во фморе Прибайкалья и Южного Забайкалья // Ботанический журнал. Т. 76, № 7. C. 1007-1016].

Karavaev, M.N. 1958. Check-list of the flora of Yakutia. Izdatel'stvo Akademiya nauk SSSR, Moscow, Leningrad, 192 pp. (in Russian). [Караваев М.Н. 1958. Конспект фморы Якутии. Москва; ЛенинграА: ИзА-во АН CCCP, 192 c.]

Kharkevich, S.S. (ed.) 1985-1996. Vascularplants of Soviet Far East, vol. 1-8. Nauka, Leningrad. (in Russian). [Сосудистые растения советского Аальнего Востока / отв. ред. С.С. Харкевич. Аенинград: Наука, 1985-1996. Т. 1-8].

Khokhryakov, A.P. 1985. Flora of the Magadan region. Nauka, Moscow, 395 р. (in Russian). [Хохряков А.П. 1985. ФАОра Магаданской области. Москва: Наука. 395 с.].

Khoreva, M.G. 2018. Floristic findings in the south of the Magadan Region. Byulleten' Moskovskogo obshchestva ispytatelei prirody. Otdel biologicheskii 123(6):71-74 (in Russian). [Хорева М.Г. 2018. ФАористические находки на юге Магаданской области // Бюлцетень Московского общества испытателей природы. ОтАел биологический. Т. 123, № 6. С. 71-74].

Komarov, V.L. 1926. Introduction to the study of vegetation of Yakutia. Trudy komissii po izucheniyn Yakutskoi ASSR 1:168 (in Russian). [Комаров, В.А. 1926. Введение в изучение растительности Якутии / / Труды комиссии по изучению Якутской АССР. Т. 1. С. 168].

Korkishko, R.I. 2002. Vascular plants. In: Cadastre of plants and mushrooms "Kedrovaya pad" Reserve: Lists of species (R.I. Korkishko, ed.), pp. 31-66, Dal'nauka, Vladivostok (in Russian). [Коркишко Р.И. 2002. СосуАистые растения // Кадастр растений и грибов заповедника "Кедровая падь” / поА реА. Р.И. Коркишко. ВАадивосток: АаАьнаука. С. 31-66].

Kozhevnikov, A.E. \& N.S. Probatova (eds.) 2006. Flora of the Russian Far East: Addenda and corrigenda to "Vascular plants of the Soviet Far East”. Vol. 1-8 (1985-1996). Dal'nauka, Vladivostok, 456 pp. (in Russian). [ФАора российского Аальнего Востока: Аополнения и изменения к изданию "Сосудистые растения советского Аальнего Востока". Т. 1-8 (1985-1996 / отв. реА. А.Е. Кожевников 
и Н.С. Пробатова. ВАадивосток: Аальнаука, 2006. 456 c.].

Kozhevnikov, A.E. \& Z.V. Kozhevnikova 2011. The complex of adventives plant species as a component of natural flora of the Russian Far East: diversity and spatial changes of taxonomic structure. V.L. Komarov Memorial Lectures 58: 5-36 (in Russian). [Кожевников A.Е., Кожевникова 3.В. 2011. Комплекс адвентивных видов растений как компонент природной флоры Аальнего Востока России: разнообразие и пространственные изменения таксономической структуры // Комаровские чтения. Вып. 58. С. 5-36].

Kozhevnikova, Z.V. \& A.E. Kozhevnikov 2016. New and rare invasive species in flora of Primorsky Territory. V.L. Komarov Memorial Lectures 64:208-218 (in Russian). [Кожевникова 3.В., Кожевников А.Е. 2016. Новые и редкие заносные виды во флоре Приморского края // Комаровские чтения. Вып. 64. С. 208-218].

Krasnoborov, I.M. \& L.I. Malyshev (eds.) 1992-2003. Flora of Siberia, vol. 1-14. Nauka, Novosibirsk. 312 pp. (in Russian). [ФАора Сибири / под реА. И.М. Красноборова и М.М. Малышева. Новосибирск: Наука, 1992-2003].

Krivobokov, L.V. 2007. The check-list of flora at western macroslope of Ikatsky ridge (Western Transbaikalia). In: Materials for the flora of Baikal Siberia (V.V. Chepinoga, ed.), pp. 47-84, Irkutskii Gosudarstvennyi Universitet, Irkutsk (in Russian). [Кривобоков А.В. 2007. Конспект фморы Западного макросклона Икатского хребта (Западное Забайкалье) / / Материалы к флоре Байкальской Сибири / под реА. В.В. Чепинога. Иркутск: ИзА-во ИГУ. C. 47-84].

Kudryavtseva, E.P., V.B. Bazarova, M.S. Lyashchevskaya \& L.M. Mokhova 2018. Common ragweed (Ambrosia artemisiffolia): the present-day distribution and the presence in the Holocene deposits of Primorskii Territory (south of the Russian Far East). V.L. Komarov Memorial Lectures 66:125-146 (in Russian with English summary). [KyAрявцева Е.П., Базарова В.Б., Аящевская М.С., Мохова А.М. 2018. Амброзия полыннолистная: современное распространение, структура сообществ и присутствие в голоценовых отложениях Приморского края (юг Аальнего Востока России) // Комаровские чтения. Вып. 66. С. 125-146.].

Kuprianov, A.N. \& Yu.K. Vinogradova (eds.) 2016. Black Book of Siberian Flora. Geo, Novosibirsk, 440 pp. (in Russian). [Черная Книга фморы Сибири / пол реА. А.Н. Куприянова и Ю.К. Виноградовой. Новосибирск: Академическое изА-во «Гео». 2016. 440 с.]

Kurbatskii, V.I. \& M.V. Olonova 1998. Floristic finds in the lower reaches of the Shilka and Argun rivers (Chita Region). Sistematicheskie zametki Gerbariya Tomskogo universiteta 90:21-22 (in Russian). [Курбатский В.И., Олонова М.В. 1998. ФАористические находки в низовьях рек Шилки и Аргуни (Читинская область) // Систематические заметки Гербария Томского университета. Т. 90. C. 21-22].

Lemke, D., C.J. Schweitzer, W. Tadesse, Y. Wang \& J.A. Brown 2013. Geospatial assessment of invasive plants on reclaimed mines in Alabama. Invasive Plant Science and Management 6:401-410.

Levine, J.M \& C.M. D’Antonio, 2003. Forecasting biological invasions with increasing international trade. Conservation Biology 17:322-326.

Lomonosova, M.N. \& E.G. Nikolin 2013. New species to the flora of Yakutia. Byulleten' Moskovskogo obshchestva ispytatelei prirody. Otdel biologicheskii 118(6):71 (in Russian). [Аомоносова М.Н., Николин Е.Г. 2013. Новые виды Аля флоры Якутии // Бюлметень МОИП. ОтАел биологический. Т. 118, №6. С. 71].

Lysenko, D.S. 2012. Sinantropic flora of Magadan Region. Severo-Vostochnyi nauchnyi tsentr Dal'nevostochnogo otdeleniya Rossiiskoi akademii nauk, Магадан, 111 c. (in Russian). [Аысенко А.С. 2012. Синантропная флора МагаАанской области. Магадан:СВНЦ АВО РАН, 111 с.].

McGeoch, M.A., S.H.M. Butchart, D. Spear, E. Marais, E.J. Kleynhans, A. Symes, J. Chanson \& M. Hoffmann 2010. Global indicators of biological invasion: species numbers, biodiversity impact and policy responses. Diversity and Distributions 16:95-108.

Mininzon, I.L. \& O.V. Trostina 2014. Black Book to the flora of Nizhny Novgorod Region: Alien plant species, native and cultivated, actively naturalized in the conditions of Nizhnii Novgorod. The third electronic version. Available from: http:/ / dront. ru/wp-content/uploads/2017/03/2014.02.11-Black_ Book-NN-III.pdf. Last accessed 13.02.2019.

Mochalova, O.A. \& M.G. Khoreva 2016. Additions to the flora of Magadan Region. Byulleten' Moskovskogo obshchestva ispytatelei prirody. Otdel biologicheskii 121(6):82-84 (in Russian). [Мочалова О.А., Хорева М.Г. 2016. Аополнения к флоре Магаданской области // Бюлметень МОИП. ОтАел биологический. Т. 121, № 6. С. 82-84].

Monaco, A. \& P. Genovesi 2014. European guidelines on protected areas and invasive alien species, Council of Europe, Strasbourg, Regional Parks Agency - Lazio Region, Rome. 58 pp.

Nagendra, H., R. Lucas, J. Pradinho Honrado, R.H.G. Jongman, C. Tarantino, M. Adamo \& P. Mairota 2013. Remote sensing for conservation monitoring: assessing protected areas, habitat extent, habitat condition, species diversity, and threats. Ecological Indicators 33:45-59.

Nechaeva, T.I. 1998. Adventive plants of Primorsky Territory. Safonovskaya tipografiya, Vladivostok, 264 pp. (in Russian). [Нечаева Т.И. 1998. ААвентивные растения Приморского края. ВАаАивосток: Сафоновская типография. 264 с.].

Nedoluzhko, V.A. \& N.I. Denisov 2001. Flora to the vascular plants of the Russky Island (Peter Great Bay in the Japan sea). Dal'nauka, Vladivostok, 98 pp. (in Russian). [Нелолужко В.А., Аенисов Н.И. 2001. ФАора сосудистых растений острова Русский (залив Петра Великого в Японском море). ВАадивосток: Аальнаука. 98 с.].

Nedoluzhko, V.A. \& O.G. Likhachyova 1986. Floristic finds in the Soviet Far East. Byulleten' Glavnogo botanicheskogo sada 141:42-45 (in Russian). [Недолужко В.А., Аихачева О.Г. 1986. ФАористические находки на советском Аальнем Востоке // Бюлметень Гцавного ботанического сада. № 141. C. 42-45].

Nedoluzhko, V.A.1984. Distribution of Ambrosia artemisiifolia (Asteraceae) in Primorsky Territory. Botanicheskii Zhurnal 69(4):527-529 (in Russian). [Недолужко B.A. 1984. Распространение Ambrosia artemisiifolia (Asteraceae) в Приморском крае // Ботанический журнал. Т. 69, № 4. C. 527-529].

Nelaev, A.A. 1998. Ambrosia - quarantine weed. Amurskaya Pravda August 11 (in Russian). [Нелаев, А.А. 1998. Амб̄розия - карантинный сорняк // Амурская Правда. 11.08].

Nikolin, E.G. 2014. Weed and alien plants of Yakutia. Rossiiskii Zhurnal Biologicheskikh Invazii 3:45-51 (in Russian 
with English summary). [Николин Е.Г. 2014. Сорные и чужеродные растения Якутии // Российский журнал биологических инвазий. № 1. С. 45-51].

Nikolin, E.G. 2016. Weed plants of Yakutia: the most dangerous and aggressive elements of flora. Nauka, Novosibirsk, 264 pp. (in Russian). [Николин Е.Г. 2016. Сорные растения Якутии: наиболее опасные и агрессивные элементы фморы. Новосибирск: Наука, 264 с.].

Nikolin, E.G. 2017. Weed plants of Yakutia: resultsand prospects of research. In: Weed plants in a changing world: current issues of studying diversity, the origin of evolution: abstracts of the report of the All-Russian scientific conference (_ ed.), pp. 87-88, Federal'nyi issledovatel'skii tsentr Vserossiiskii institut geneticheskikh resursov rastenii, Saint-Petersburg (in Russian). [Николин Е.Г. 2017. Сорные растения Якутии: итоги и перспективы исследований // Copные растения в изменяющемся мире: актуальные вопросы изучения разнообразия, происхождения эвоАюции: тезисы доклада всероссийской научной конференции / по реА. _. Санкт-Петербург: ФИЦ ВИР. C. 87-88].

Notov, A.A., Yu.K. Vinogradova \& S.R. Maiorov 2010. About problem of developing and maintaining regional Black lists. Rossiiskii Zhurnal Biologicheskikh Invarii 4:54-86 (in Russian with English summary). [Нотов А.А., Виноградова Ю.К., Майоров С.Р. 2010. О проблеме разработки и ведения региональных Черных книг // Российский журнал биологических инвазий. № 4. C. 54-86].

Panasenko, N.N. 2014. Black list of flora of the Bryansk Region. Rossiiskii Zhurnal Biologicheskikh Invazii 2:127-132 (in Russian with English summary). [Панасенко, Н.Н. 2014. Черный список флоры Брянской области // Российский журнал биологических инвазий. № 2. C. 127-132].

Pazdnikova, N.M. \& V.V. Chepinoga 2013. Check-list of the vascular flora of the Onon-Dahuria Region, central part (South-East Transbaikalia, Russia). Izvestiya Irkutskogo gosudarstvennogo universiteta. Seriya Biologiya. Ecologiya 6(1):32-60 (in Russian with English summary). [ПазАникова Н.М., Чепинога В.В. 2013. Конспект флоры сосудистых растений центральной части Ааурии ононской (Юго-Восточное Забайкалье) // Известия Иркутского государственного университета. Серия Биология. Экология. Т. 6, № 1. С. 32-60].

Pimenov, M.G. 1987. Fam. Celery-Apiaceae. In: Vascular plants of the Soviet Far East (S.S. Kharkevich, ed.), pp. 203277, Nauka, Leningrad (in Russian). [Пименов М.Г. 1987. Сем. Сельдереевые-Аріасеае / под ред. С.С. Харкевича. АенинграА: Наука. С. 203-277].

Pimenov, M.G., A.P. Khokhryakov \& R.E. Pimenova 1966. Floristic news from Southern Primorye. Byulleten' Glavnogo botanicheskogo sada AN SSSR 189:53-76 (in Russian). [Пименов М.Г., Хохряков А.П., Пименова Р.Е. ФАористические новинки из Южного Приморья // Бюмлетень ГАавного ботанического сада АН СССР. № 63. С. 78-79].

Pimenova, E.A. 2016. Vascular plants. In: Plants, fungi and lichens of the Sikhote-Alin Reserve (E.A. Pimenova, ed.), pp. 172-365, Dal'nauka, Vladivostok (in Russian with English abstract). [Пименова E.А. 2016. Сосудистые растения // Растения, грибы и Аишайники СихотэА^инского заповедника / под реА. Е.А. Пименовой. В^адивосток: Аальнаука. С. 172-365].

Probatova, N.S. 1971. New species of bluegrass (Poa L.) from the Far East. Novosti sistematiki yysshykh rastenii 8: 25-57 (in Russian). [Пробатова Н.С. 1971 Новые виды мятлика (Poa L.) с Аальнего Востока //Новости систематики высших растений. Т. 8. С. 25-57].

Probatova, N.S. 1993. Overview of the mint family (Lamiaceae) in flora of the Russian Far East. V.L. Komarov Memorial Lectures 41:29-53 (in Russian). [Пробатова Н.С. 1993. Обзор семейства яснотковых (Lamiaceae) во фморе российского Аальнего Востока // Комаровские чтения. Вып. 41. С. 29-53].

Probatova, N.S. 2007. Chromosome numbers in Poaceae family and their significance for taxonomy, phylogeny and phytogeography (using the example of the cereals of the Russian Far East). V.L. Komarov Memorial Lectures 55:9103 (in Russian). [Пробатова Н.С. 2007. Хромосомные чис $а$ в семействе Роасеае и их значение мля систематики, филогении и фитогеографии (на примере зАаков Аацьнего Востока России) // Комаровские чтения. Вып. 55. С. 9-103].

Prokopenko, S.V. 2011. Floristic finds in Primorsky Territory. Byulleten' Moskovskogo obshchestva ispytatelei prirody. Otdel biologicheskii 116(3):77-80 (in Russian). [Прокопенко C.B. 2011. ФАористические находки в Приморском крае / / Бюл^етень Московского общества испытателей природы. ОтАел биологический. Т. 116, № 3. С. 77-80].

Prokopenko, S.V. 2014. About finding Plantago salsa Pall. (Plantaginaceae) in Primorsky Territory. Byulleten' Moskovskogo obshchestva ispytatelei prirody. Otdel biologicheskii 119(3):76 (in Russian). [Прокопенко C.B. 2014. О находке Plantago salsa Pall. (Plantaginaceae) в Приморском крае // Бю метень Московского общества испытателей природы. ОтАел биологический. Т. 119, № 3. С. 76].

Pykhalova, T.A. \& O.A. Anenkhonov 2014. Local flora "Dzelinda" (Northen Baikal). Botanicheskii Zhurnal 99(9): 1043-1055 (in Russian with English summary). [Пыхамова Т.А., Аненхонов О.А. 2014. Аокальная флора “Азелинда” (Северное Прибайкалье) // Ботанический журнал. Т. 99, № 9. С. 1043-1055].

Pykhalova, T.D., T.G. Boikov \& O.A. Anenkhonov 2007. Flora of the Ulan-Burgas Range (Eastern Baikal). Buryatskii Nauchnyi Tsentr SO RAN, Ulan-Ude, 126 pp. (in Russian). [Пыхалова Т.А., Бойков Т.Г., Аненхонов О.А. 2007. ФАора хребта У Аан-Бургасы (Восточное Прибайкалье). УАан-УАэ: ИзА-во БНЦ СО РАН. 126 с.].

Raizada, P., A.S. Raghubanshi \& J.S.Singh 2008. Impact of invasive alien plant species on soil processes: a review. Proceedings of the National Academy of Sciences India Section B, Biological Sciences 78: 288-298.

Regulation (EU) No 1143/2014. (n. d.). Regulation (EU) No 1143/2014 of the European Parliament and of the Council of 22 October 2014 on the prevention and management of the introduction and spread of invasive alien species. Official Journal of the European Union, L, 317, 4.11.2014, p. 35-55. Available from: http://data.europa. euleli/reg/2014/1143/oj. Last accessed 18.07.2019.

Rubtsova, T.A. 2000. Adventive element of the Small Khingan. In: Human dimension in regional development: abstracts of the $V$ international symposium, pp. 194-196, Institut kompleksnogo analiza regional'nykh problem DVO RAN, Birobidzhan (in Russian). Руббцова T.A. 2000. ААвентивный элемент флоры Мацого Хингана // Человеческое измерение в региональном развитии: тезисы V межАународного симпозиума. Биробиджан: ИКАРП АВО РАН. С. 194-196].

Rubtsova, T.A. 2002. Flora of the Lesser Kbingan. Dal'nauka, Vladivostok, 194 pp. (in Russian). [Рубцова Т.А. 2002. ФАора Малого Хингана. ВАадивосток: Аальнаука. 194 с.]. 
Rubtsova, T.A. 2017. Flora of the Jewish Autonomous Region. Antar, Khabarovsk, 241 pp. (in Russian). Рубццова T.A. 2017. ФАора Еврейской автономной области. Хабаровск: Антар. 241 с.].

Ruiz, G.M. \& J.T. Carlton 2003. Invasion vectors: a conceptual framework for management. In: Invasive species: vectors and management strategies (G.M. Ruiz \& J.T. Carlton, eds), pp. 459-504, Island Press, Washington, DC.

Schlotgauer, S.D. \& A.I. Schroeter 1969. New plant species for the flora of the Khabarovsk Territory. Bulletin of the Main Botanical Garden 69:81-83 (in Russian). [Шиотгауэр С.А., Шретер А.И. 1969. Новые виды растений Аля флоры Хабаровского края // Бюлметень Главного ботанического сада. Вып. 69. С. 81-83].

Smirnov, A.A. 2009. South Sakhalin is the new location of Cakile eduntula (Bigel.) Hook. (Brassicaceae) in the Russian Far East. Byulleten' Moskovskogo obshchestva ispytatelei prirody. Otdel biologicheskii 114(6):72-73 (in Russian). [Смирнов А.А. 2009. Южный Сахалин - новое местонахождение Cakile eduntula (Bigel.) Hook. (Brassicaceae) на российском Аальнем Востоке // Бюлметень Московского общества испытателей природы. ОтАел биологический. Т. 114, № 6. С. 72-73].

Starchenko, V.M. 2001. Checklist of the flora of the Amur Region. V.L. Komarov Memorial Lectures 48:5-55 (in Russian). [Старченко B.M. 2001. Конспект флоры Амурской об̆ласти / / Комаровские чтения. Вып. 48. С. 5-55].

Starchenko, V.M., G.F. Darman \& T.N. Veklich 2014. Floristic records in the Amur Region. Botanicheskii Zhurnal 99(5):617-622 (in Russian with English summary). [Старченко B.М., Аарман Г.Ф., Веклич Т.Н. 2014. ФАористические находки в Амурской области / / Ботанический журнал. Т. 99, № 5. С. 617-622].

Starodubtseva, E.A., O.V. Morozova \& A.Ja. Grigor'evskaja 2014. Materials to the Black book of the Voronezh Region. Rossiiskii Zhurnal Biologicheskikh Invazii 7(2):133-149 (in Russian with English summary). [Стародубцева Е.A., Морозова О.В., Григорьевская А.Я. 2014. Материалы к "Черной книге Воронежской области" // Российский журнал биологических инвазий. Т. 7, № 2, C 133-149].

Sutkin, A.V. 2010. Urbanoflora of the Ulan-Ude city. Buryatskii Nauchnyi Tsentr SO RAN, Ulan-Ude, 142 pp. (in Russian). [Суткин А.В. 2010. Урбанофлора города У УАэ. УАан-УАэ: ИзА-во БНЦ СО РАН. 142 с.].

Tarabukin, A.A. 1932. Field herbs of Yakutia. Guide to the weeds. Book publishing, Yakutsk, 142 pp. (in Russian). [Тарабукин А.А. 1932. Полевые травы Якутии. Определитель сорных трав. Якутск: кн. изАат. 142 с.].

Taran, A.A. 1990. Vascular plants. In: Flora, myco- and lichenobiota of the Lazousky Reserve, pp. 61-126, Dal'ne vostochnoe otdelenie AN SSSR, Vladivostok (in Russian). [Таран А.А. 1990. Сосудистые растения // ФАора, мико- и михенобиота Аазовского заповедника. ВАадивосток: АВО АН СССР. С. 61-126].

Tolmachev, A.I. (ed.) 1966. Guide to the plants from Primorye and Priamurye. Nauka, Moscow, Leningrad, 492 pp. (in Russian). [Определитель растений Приморья и Приамурья / под реА. А.И. Толмачева. Москва; АенинграА: Наука, 1966. 492 с.].

Tolmachev, A.I. (ed.) 1974. Guide to the bigher plants of Yakutia. Nauka, Novosibirsk, 544 pp. (in Russian). [Опредемитель высших растений Якутии / поА реА. А.И. Толмачева. Новосибирск: Наука, 1974. 544 с.].
Verkhozina, A.V., S.G. Kazanovskii, N.V. Stepantsova \& D.A. Krivenko 2013. Floristic findings in the Republic of Buryatia and Irkutsk Region. Turçaninowia 16(3):44-52 (in Russian with English summary). Верхозина A.B., Казановский С.Г., Степанцова Н.В., Кривенко А.А. 2013. ФАористические находки в Республике Бурятия и Иркутской области // Turczaninowia. Т. 16, № 3. C. 44-52].

Vilá, M., C. Basnou, S. Gollasch, M. Josefsson, J. Pergl \& R. S calera 2009. One hundred of the most invasive alien species in Europe. In: Handbook of Alien Species in Europe (J.A. Drake, ed.), pp. 133-264, Springer, Berlin.

Vinogradova, Yu., J. Pergl, F. Essl, M. Hejda, M. van Kleunen, regional contributors \& P. Pyšek 2018. Invasive alien plants of Russia: insights from regional inventories. Biological Invasions 20:1931-1943.

Vinogradova, Yu.K. \& A.N. Kupriyanov (eds.) 2016. Black. Book of Siberian flora. Geo, Novosibirsk, 440 pp. (in Russian). [Черная книга фморы Сибири / под реА. Ю.К. Виноградовой и А.Н. Куприянова. Новосибирск: Академическое изА-во “Гео”, 2016. 440 с.].

Vinogradova, Yu.K. 2005. Experimental study of invasive populations of canadian fleabane (Conyza canadensis (L.) Cronquist.). Byulleten' Glavnogo botanicheskogo sada 189:5376 (in Russian). [Виноградова Ю.К. 2005. Экспериментальное изучение инвазионных популяций мелкомепестника канаАского (Conyza canadensis (L.) Cronquist) // Бюлметень ГАавного ботанического сада. № 189. C. 53-76].

Vinogradova, Yu.K. 2006. Stages of the secondary area forming and variability of Echinocystis lobata (Michx.) Torr. et Gray. Byulleten' Glavnogo botanicheskogo sada 192: 8-23 (in Russian). [Виноградова Ю.К. 2006. Этапы формирования вторичного ареала и изменчивость инвазионных попумяций Echinocystis lobata (Mich.) Torr. et Gray // Бюмлетень ГАавного ботанического сала. № 192. C.8-23.

Vinogradova, Yu.K., S.R. Maiorov \& A.A. Notov 2011. Black Book of flora of Tver Region: alien plant species in the ecosystems of the Tver Region. KMK, Moscow, 292 pp. (in Russian). [Виноградова Ю.К., Майоров С.Р., Нотов A.А. 2011. Черная книга фморы Тверской области: чужеродные виды растений в экосистемах Тверского региона. Москва: КМК. 292 с.].

Vinogradova, Yu.K., S.R. Maiorov \& L.V. Khorun 2010. Black Book of flora of Central Russia. Alien plant species in the ecosystems of the Middle Russia. GEOS, Moscow, 512 pp. (in Russian). [Виноградова Ю.К., Майоров С.Р., Хорун А.В. 2010. Черная книга флоры Срелней России. Чужеродные виды растений в экосистемах Средней России. Москва: ГЕОС. 512 с.].

Vorob'ev, D.P. 1954. On the issue of invasive and weed plants in Primorsky Territory. V.L. Komarov Memorial Lectures 4:3-22 (in Russian). Воробьев А.П. 1954. К вопросу о заносных и сорных растениях в Приморском крае // Комаровские чтения. Вып. 4. С. 3-22].

Vorob'ev, D.P. 1964. On some one new and rare species of flora of Primorya and Priamurya. V.L. Komarov Memorial Lectures 12:46-68 (in Russian). [Воробьев А.П. 1964. О некоторых новых и редких видах во флоре Приморья и Приамурья // Комаровские чтения. Вып. 12. С. 46-68].

Voroshilov, V.N. 1966. Flora of the Soviet Far East. Nauka, Moscow, 478 pp. (in Russian). [Ворошилов B.H. 1966. Фцора советского Аацьнего Востока. Москва: Наука, 478 c.]. 
Voroshilov, V.N. 1982. Key to plants of the Soviet Far East. Nauka, Moscow, 672 pp. (in Russian). [Ворошилов B.H. 1982. Определитель растений советского Аальнего Востока. Москва: Наука, 672 с.].

Yakubov, V.V. \& O.A. Chernyagina 2004. Catalog of flora of Kamchatka (Vascularplants). Kamchatpress, PetropavlovskKamchatskii, 165 pp. (in Russian). [Якубоов B.В., Чернягина О.А. 2004. Каталог флоры Камчатки (сосудистые растения). Петропавловск-Камчатский: Камчатпресс. 165 c.].

Yakubov, V.V. 2010. Illustrated flora of the Kronotsky Reserve (Kamchatka): vascular plants. Institute of Biology and Soil Sciense, Vladivostok, 296 pp. (in Russian). [Якубов B.B.
2010. И^^юстрированная флора Кроноцкого заповедника (Камчатка): сосудистые растения. ВАадивосток: БПИ АВО РАН. 296 с.].

Yurtsev, B.A. (ed.) 1987. Flora Arctica URSS. Nauka, Leningrad. Vol. 10. 411 pp. (in Russian). [Арктическая флора СССР / под реА. Б.А. Юрцева. Аенинград: Наука, 1987. Вып. 10. 411 с.].

Yurtsev, B.A., T.M. Koroleva, V.V. Petrovsky, T.G. Polozova, et al. 2010. Synopsis of the Chukechi tundra flora. BBM. SaintPetersburg, 628pp. (in Russian). [Юрцев Б.А., Королева Т.М., Петровский В.В., Полозова Т.Г. и Ар. 2010. Конспект флоры Чукотской тунары. СПб.: ВВМ. 628 c.]. 